\title{
Marriage of Necessity: Same-Sex Marriage and Religious Liberty Protections
}

Robin Fretwell Wilson

Follow this and additional works at: https://scholarlycommons.law.case.edu/caselrev

Part of the Law Commons

\section{Recommended Citation}

Robin Fretwell Wilson, Marriage of Necessity: Same-Sex Marriage and Religious Liberty Protections, 64 Case W. Rsrv. L. Rev. 1161 (2014)

Available at: https://scholarlycommons.law.case.edu/caselrev/vol64/iss3/16

This Symposium is brought to you for free and open access by the Student Journals at Case Western Reserve University School of Law Scholarly Commons. It has been accepted for inclusion in Case Western Reserve Law Review by an authorized administrator of Case Western Reserve University School of Law Scholarly Commons. 


\title{
MARRIAGE OF NECESSITY: SAME-SEX MARRIAGE AND Religious Liberty Protections*
}

\author{
Robin Fretwell Wilson
}

\begin{abstract}
Since the U.S. Supreme Court heard oral arguments in Hollingsworth $v$. Perry and U.S. $v$. Windsor, the number of states recognizing same-sex marriage has exploded. Even though the Supreme Court "stopped short of deciding whether the Constitution guaranteed a right to same-sex marriage," the Court's basic

* Between the date of the Law Review Symposium on October 22, 2013, and final publication, a flurry of activity around same-sex marriage has occurred; state elections have also changed which party controls the legislature and occupies the governor's office in at least one state. See infra notes 225 and 232 (discussing Virginia). This Article takes into account changes to same-sex marriage laws as of January 14, 2014, but it uses a snapshot of the political terrain as of the symposium date, October 22, 2013.

$\dagger \quad$ Roger and Stephany Joslin Professor of Law and Director, Family Law and Policy Program, University of Illinois College of Law. I am grateful to Helen Alvarez, Joyce Chen, Rep. Gordon Denlinger, Josh Fairfield, Richard Garnett, Kent Greenawalt, Howard Katz, Andy Koppelman, Douglas Laycock, Tim MacDonnell, Steve McAllister, Tamara Piety, Steven Smith, Mark Tushnet, and Todd Zywicki for their thoughtful comments, as well as the insights of the panelists and audience at the Case Western Law Review Symposium and presentations at the Institute for American Constitutional Heritage at the University of Oklahoma, UC Davis Law School, George Mason University School of Law, Kansas University School of Law, Penn State University School of Law, the International Academy for the Study of the Jurisprudence of the Family, and the Law \& Religion Roundtable at Washington University School of Law. I would also like to thank the students in the Seminar for Gay Rights and the Courts at Yale University's Trumbull College for our dinner conversation about religious liberty and same-sex marriage. I am part of a group that urges robust religious liberty protections in any same-sex marriage legislation. This group, which takes no position for or against same-sex marriage as a group in its filings, includes: Thomas C. Berg (St. Thomas (Minn.)), Carl H. Esbeck (Missouri), Richard W. Garnett (Notre Dame), Edward McGlynn Gaffney (Valparaiso), and myself. This group works in tandem with a second group of law professors, all of whom support same-sex marriage and religious liberty protections; that group includes Douglas Laycock (Virginia), Bruce S. Ledewitz (Duquesne), Christopher C. Lund (Wayne State) and Michael Perry (Emory), as well as Professor Berg. I am indebted to Cameron Flynn for his diligent research, without which the empirical analysis presented here would not have been possible.
\end{abstract}


vindication of same-sex couples' right to equal treatment has spurred newly enacted legislation as well as judicial decisions recognizing same-sex marriage. The net effect has been to erase a boundary that had largely confined same-sex marriage to the Northeast.

In jurisdictions that voluntarily enacted same-sex marriage, religious liberty protections for religious objectors who adhere to a heterosexual view of marriage - exempting them from requirements to facilitate marriages inconsistent with their religious beliefs, by providing a reception hall, for example - proved vital to the legislation's success. In many Enacting Jurisdictions, more robust protections resulted in successful legislation where a bill with thinner or nonexistent protections had failed just years before.

Even though same-sex marriage recognition in the Enacting Jurisdictions has thus far been yoked to religious liberty protectionsdelivering important gains to supporters and opponents alikeprominent voices on each side now caution against compromise. Buoyed by their recent judicial victories, some supporters have hardened against compromise. With the recent spate of favorable judicial decisions, compromise may simply appear increasingly unnecessary.

Opponents are hardening in their stance, too. Far from folding in the face of the momentum carrying same-sex marriage across the country, some thought-leaders urge opponents to double down on their opposition. These opponents see only one way forward: fighting to the bitter end.

This Essay contends that we stand at a critical moment in the same-sex marriage movement. A clear-eyed examination of the marriage movement's success - and the challenges facing it going forward - reveals that both sides will benefit from remaining at the bargaining table, although the gains to each will be different.

For same-sex couples, voluntary recognition of same-sex marriage by legislation delivers the benefits and security of marriage today. True, many believe that the juggernaut of lower court decisions requiring same-sex marriage will lead in the near term to a favorable Supreme Court decision. Although that result is increasingly likely, it is nonetheless not assured. Moreover, the unanimity of decisions striking marriage bans may, ironically, delay an ultimate resolution by the Supreme Court, which often declines review until a meaningful circuit split arises. For marriage equality opponents, the voluntary embrace of same-sex marriage permits legislators to consider competing considerations, including concrete ways to permit those who adhere to a traditional view of marriage to continue to do so without facing civil lawsuits or government penalty.

Part I shows that same-sex marriage has spread across America through three different avenues: judicial decisions, state laws enacting same-sex marriage, and ballot initiatives - with judicial decisions being fraught with risk for religious dissenters while legislative or 
popular enactments offer important, if flawed, protections to religious organizations and individuals.

Parts II and III document that a "perfect storm" of characteristics favoring marriage equality in jurisdictions that voluntarily embraced same-sex marriage, together with extensive bargaining around religious liberty, nudged same-sex marriage legislation over the finish line. Even with these favorable conditions, marriage equality bills just barely squeaked over the line to enactment, helped by religious liberty exemptions.

That advantageous political terrain is now nearly exhausted, as Part IV documents. Going forward, one would reasonably expect more robust religious liberty protections to play a central part in any legislative compromises over same-sex marriage, at least for the near term.

Part V evaluates the impulse of some opponents of same-sex marriage to dig in, resisting same-sex marriage at all costs. In part, opponents rely on constitutional bans against same-sex marriage. Constitutional bans may well not survive judicial challenge. However, even without court action striking a ban, constitutional amendments banning same-sex marriage do not provide the bulwark against change that some assume since many can be repealed almost as easily as enacting ordinary legislation.

Part VI concludes that, in the tougher political terrain that looms, those who care about marriage equality can continue to sew up legislative victories - but the price tag in the short term will be to agree to robust religious liberty protections for dissenters. Those who wish to protect religious objectors from the unintended consequences of same-sex marriage should act with all deliberate speed to lock in robust religious liberty protections, because the window for securing them is almost certainly closing. 
Case Western Reserve LaW Review · Volume $64 \cdot$ Issue $3 \cdot 2014$ Marriage of Necessity

\section{Contents}

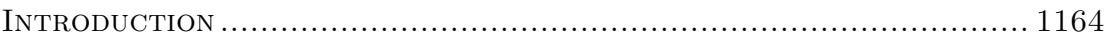

I. The Importance of Bargaining Before Judicial Action ....... 1176

II. A (Closing) Political Window for Securing Religious LIBERTY ............................................................... 1195

III. A Cluster of Political Factors Supported Marriage

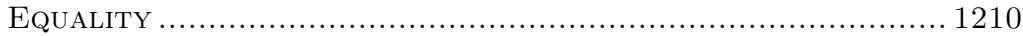

IV. The Political Terrain Going Forward .............................. 1218

V. Difficult Terrain Does not Mean Opponents Can Hold Out ..... 1228

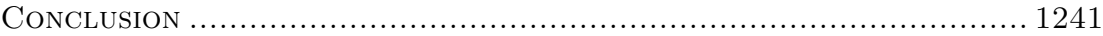

ApPENDiX

Table A1: States Recognizing Same-Sex Marriage and the

Methods by Which Same-Sex Marriage Is Recognized as OF JAN. 14, 2014

Table A2: State-Wide Sexual Orientation Nondiscrimination

MeAsures

Table A3: Religious Liberty Protections in Same-Sex Marriage

STATES ............................................................ 1253

Table A4: State Political Climate....................................... 1258

Table A5: Vote Margins in Enacting Jurisdictions.................... 1262

Table A6: Same-Sex Marriage Support (and Opposition) in Constitutional Ban States. 1265

Table A7: Support for Same-Sex Marriage by Age, With and

Without the Oldest Generation................................ 1266

\section{INTRODUCTION}

In the space of nine short months - from oral arguments before the U.S. Supreme Court in Hollingsworth v. Perry ${ }^{1}$ and United States $v$. Windsor ${ }^{2}$ to a pair of federal district court decisions invalidating state constitutional bans on same-sex marriage in direct reliance on

1. 133 S. Ct. 2652, 2668 (2013) (reinstating the federal district court decision invalidating Proposition 8, Perry v. Schwarzenegger, 704 F. Supp. 2d 921 (N.D. Cal. 2010)). The United States Court of Appeals for the Ninth Circuit had affirmed the lower court's decision in Perry v. Brown, 671 F.3d 1052 (9th Cir. 2012), but the Supreme Court found that the parties lacked standing to appeal. 133 S. Ct. at 2668.

2. $\quad 133$ S. Ct. 2675, 2696 (2013) (holding that the Fifth Amendment requires the federal government to recognize same-sex marriages that are valid under state law). The Court heard oral argument in the cases on March 26 and 27, 2013. Argument Audio, Supreme Court of THE United StATES (March 26 \& 27, 2013), http://www.supremecourt.gov/or al_arguments/argument_audio.aspx (listing the date of oral arguments). 
Windsor - the number of states recognizing same-sex marriage has exploded. If one includes the now-stayed decisions in Oklahoma ${ }^{4}$ and Utah, ${ }^{5}$ as of January 14, 2014, 19 states and the District of Columbia permit same-sex marriage, a leap from ten states mere months before ${ }^{6}$ Newly enacted legislation in five states ${ }^{7}$ and judicial decisions in four others, ${ }^{8}$ together with Hollingsworth's restoration of same-sex marriage

3. Bishop v. United States ex rel. Holder, No. 04-CV-848-TCK-TLW, 2014 WL 116013, at *33 (N.D. Okla. Jan. 14, 2014) (striking Oklahoma's constitutional same-sex marriage ban on equal protection grounds, using rational basis review); Kitchen v. Herbert, No. 2:13-cv-217, 2013 WL 6697874, at *30 (D. Utah Dec. 20, 2013) (striking Utah's constitutional same-sex marriage ban on due process and equal protection grounds), stay granted, $134 \mathrm{~S}$. Ct. 893 (2014).

4. In Bishop, the district court judge stayed the decision until "final disposition of any appeal to the Tenth Circuit Court of Appeals." Bishop, 2014 WL 116013, at *33.

5. In Herbert, the district court judge did not stay the decision while on appeal to the U.S. Court of Appeals for the Tenth Circuit. Herbert, 2013 WL 6697874. On January 6, 2014, the Supreme Court stayed the decision "pending final disposition of the appeal by the United States Court of Appeals for the Tenth Circuit." Herbert v. Kitchen, 134 S. Ct. 893, 893 (2014). In the weeks between the decision and the Supreme Court's stay, nearly 1,300 same-sex couples married. While the federal government has said it will acknowledge the marriages as valid, Utah is "largely refusing to do so." Charlie Savage and Jack Healy, U.S. to Recognize 1,300 Marriages Disputed by Utah, N.Y. Times Jan. 11, 2014, at A1.

6. Eleven jurisdictions permit same-sex marriage by legislation alone: Delaware, District of Columbia, Hawaii, Illinois, Maryland, Minnesota, New Hampshire, New York, Rhode Island, Vermont, and Washington. See infra Table A1. One state, Connecticut, passed legislation recognizing same-sex marriages on the heels of a judicial decision requiring recognition. See infra Table A1. One state, Maine, adopted same-sex marriage by a ballot initiative. See infra Table A1. Finally, seven states recognize same-sex marriage as a result of a judicial decision alone: California, Iowa, Massachusetts, New Jersey, New Mexico, Oklahoma, and Utah. See infra Table A1.

As of this writing, the decisions in Utah and Oklahoma are stayed. See supra notes $4-5$.

7. Since March 2013, Delaware, Hawaii, Illinois, Minnesota, and Rhode Island have all legislatively enacted same-sex marriage. See H.B. 75, 147th Gen. Assemb. (Del. 2013) (codified as Del. Code Ann. Tit. $13 \S$ 101 (2013)); S.B.1, 27th Leg., 2d Spec. Sess. (Haw. 2013) (codified as Haw. Rev. Stat. \$572-1 (West 2013)); S.B. 0010, 98th Gen. Assemb. (Ill. 2013) (to be codified at 750 Ill. Comp. Stat. 5/201 (2014)); H.F. 1054, 88th Sess. (Minn. 2013) (codified as Minn. Stat. Ann. §517.01 (West 2013)); H.B. 5015B, 2013 Reg. Sess. (R.I. 2013) (codified as R.I. Gen. Laws § 15-1-1 (2013)). See also Table A1 infra.

8. See Bishop v. United States ex rel. Holder, No. 04-CV-848-TCK-TLW, 2014 WL 116013, at *33 (N.D. Okla. Jan. 14, 2014); Kitchen, 2013 WL 
in California, ${ }^{9}$ erased a boundary that had largely confined same-sex marriage to the Northeast. ${ }^{10}$

Even though the Supreme Court "stopped short of deciding whether the Constitution guaranteed a right to same-sex marriage,"11 the Court's basic vindication of same-sex couples' right to equal treatment ${ }^{12}$ hastened a spate of judicial decisions requiring state recognition of same-sex marriage. ${ }^{13}$ Just as significant, the Court's "historic decisions"14 fueled state legislation as well. In Hawaii, Senator Brickwood Galuteria introduced SB1 to enact same-sex marriage during a special legislative session. The bill's text explained that "[t]he legislature acknowledges the recent decision of the United

6697874 at *30; Griego v. Oliver, 316 P.3d 865 (N.M. 2013) (authorizing same-sex marriage in New Mexico); Garden State Equality v. Dow, 82 A.3d 336 (N.J. Super. Ct. Law Div. 2013) (striking down New Jersey's civil union statute as violative of the New Jersey Constitution and requiring the state to permit same-sex couples to marry). Prior to Griego, New Mexico law neither explicitly banned nor authorized samesex marriages. Griego, 316 P.3d at 871.

9. Hollingsworth v. Perry, 133 S. Ct. 2652 (2013).

10. Of the early exceptions to the geographic cluster (Iowa, D.C. and Maryland), Iowa recognized same-sex marriage by judicial decision while D.C. and Maryland did so by statute. See Varnum v. Brien, 763 N.W.2d 862, 906 (Iowa 2009); see also Bill 18-0482 (D.C. 2009) (codified as D.C. Code § 46-401 (LexisNexis 2012)); H.B. 438, 2012 Leg., 430th Sess. (Md. 2012) (codified as MD. CODE Ann., FAm. LAW §§2-201 (LexisNexis 2012)). Maryland voters subsequently approved Maryland's same-sex marriage law by popular referendum by a vote of $52 \%$ to $48 \%$. See infra note 114.

11. Adam Liptak, Utah Ruling Means No Respite for the Supreme Court on Same-Sex Marriage, N.Y. Times, Dec. 27, 2013, at A1.

12. The federal district court decision invalidating Oklahoma's constitutional ban on same-sex marriage references Windsor 65 times. See Bishop, 2014 WL 116013, at *17 ("This Court interprets Windsor as an equal protection case holding that [the invalidated federal Defense of Marriage Act ("DOMA")] drew an unconstitutional line between lawfully married opposite-sex couples and lawfully married same-sex couples). The decision invalidating Utah's constitutional ban on samesex marriage references Windsor 34 times. See Kitchen, 2013 WL 6697874 , at *7 ("The court agrees with Justice Scalia's interpretation of Windsor and finds that the important federalism concerns at issue here are nevertheless insufficient to save a state-law prohibition that denies the Plaintiffs their rights to due process and equal protection under the law.").

13. See supra note 8.

14. Marriage at the Supreme Court in 2013, Freedom to MARRY (June 26, 2013), http://www.freedomtomarry.org/landscape/entry/c/supremecourt ("The Supreme Court's historic decisions will dramatically improve the lives of same-sex couples across the country, allowing many couples the ability to protect each other and their families."). 
States Supreme Court in United States v. Windsor"15 and seeks to "ensure that same-sex couples are able to take full advantage of federal rights, benefits, protections, and responsibilities granted to married opposite-sex couples by allowing same-sex couples to marry under the laws of this State."16 In Illinois, where proponents introduced the ultimately successful same-sex marriage bill before the Supreme Court's later decisions, Windsor lent further support. ${ }^{17}$

Even before this Court-powered juggernaut toward marriage equality, state recognition of same-sex marriage over the last decade ${ }^{18}$ evolved from a labored, slow moving phenomenon to a steady, seemingly inexorable one. ${ }^{19}$ As Figure 1 illustrates,${ }^{20}$ the movement

15 S.B.1, 27th Leg., 2d Spec. Sess. (Haw. 2013) (codified as Haw. Rev. StAT. §572-1 (West 2013)).

16. Id. Governor Abercrombie also referenced Windsor when he floated his own bill text to recognize same-sex marriage. See Press Release, Gov. Neil Abercrombie, Proclamation and Marriage Equity Bill (Sept. 9, 2013) ("TT]he Governor believes that, in keeping with the United States Supreme Court's recent decision in United States v. Windsor, 133 S. Ct. 2675 (2013), the State of Hawaii should extend to same-sex couples the right to marry and receive all the same rights, benefits, protections, and responsibilities of marriage as opposite-sex couples receive under the laws of this State.").

17. See David Masci, Supreme Court's DOMA decision driving same-sex marriage efforts in states, PEW RES. CENTER (Oct. 21, 2013), http://www.pewresearch.org/fact-tank/2013/10/21/supreme-courtsdoma-decision-driving-same-sex-marriage-efforts-in-states/ (discussing Illinois's prior attempts to legislate same-sex marriage).

18. Recognition of same-sex marriage rights started in 2003 with Goodridge v. Dep't of Pub. Health, 798 N.E.2d 941 (Mass. 2003) and gained speed after 2008, which was marked by a judicial decision in California, In re Marriage Cases, 183 P.3d 384 (Cal. 2008), as well as a judicial decision and subsequent legislation in Connecticut. See Kerrigan v. Comm'r of Pub. Health, 957 A.2d 407 (Conn. 2008); S.B. 899, 2009 Legis., Jan. Sess. (Conn. 2009) (codified as Conn. Gen. Stat. § 46b-20 (2009)).

19. See Liptak, supra note 11 ("Since then, the pace of change has been very rapid. . . . [I]n March, same-sex marriage was permitted in nine states and the District of Columbia. If the Utah decision stands, the number of states allowing such marriages will have doubled, to 18.").

20. Figure 1 reflects the date that a judicial decision was handed down or legislation was signed into law (or for some states, both). These dates do not always match the first date on which same-sex couples could marry. Some states, like Illinois, postponed by months the date when state officials were authorized to issue marriage licenses to same-sex couples. See S.B. 0010, 98th Gen. Assemb. (Ill. 2013) (to be codified at 750 ILL. Comp. Stat. 5/201 (2014)). 
gathered momentum when state legislatures began acting independently, as Vermont did, to "ensure that equality was there." 21

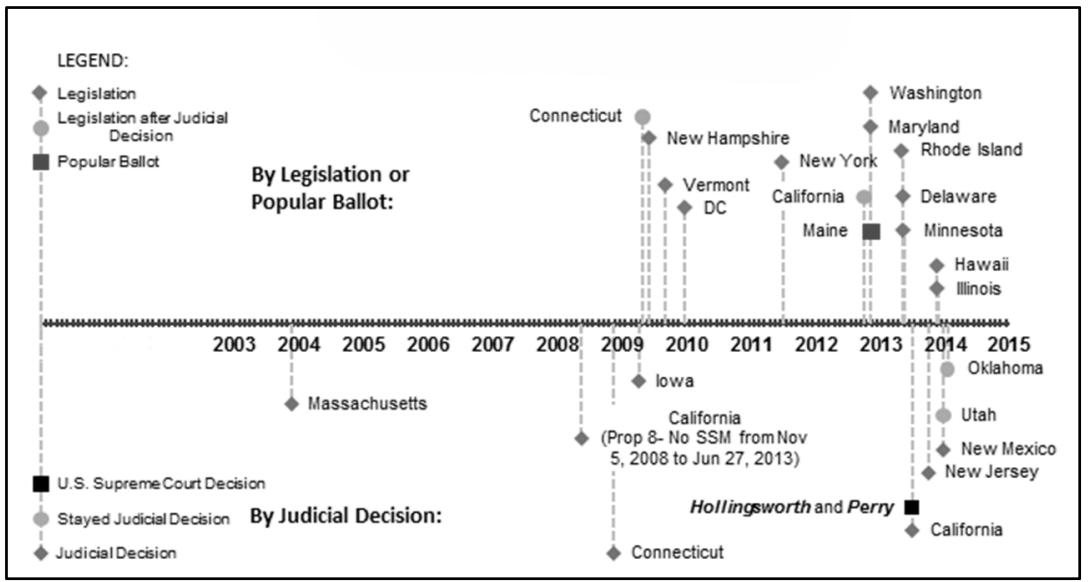

Figure 1: Same-Sex Marriage Timeline

In jurisdictions that enacted same-sex marriage ("Enacting Jurisdictions"), ${ }^{22}$ religious liberty protections for religious objectors who adhere to a heterosexual view of marriage - exempting them from requirements to facilitate marriages inconsistent with their religious beliefs, like providing a reception hall-proved vital to the legislation's success. After New York's watershed same-sex marriage law, the New York Times observed that the religious liberty protection:

proved to be the most microscopically examined and debatedand the most pivotal - in the battle over same-sex marriage. Language that Republican senators inserted into the bill legalizing same-sex marriage provided more expansive

21. Telephone Interview by Anthony Kreis with Heidi Schuermann, Member of the Vt. House of Representatives (June 28, 2012). See Anthony Kreis \& Robin Fretwell Wilson, Embracing Compromise: Marriage Equality and Religious Liberty in the Political Process, 15 Geo. J. Gender \& L. (forthcoming 2014).

22. The Enacting Jurisdictions either recognized same-sex marriage by legislation alone or with legislation codifying a judicial decision requiring same-sex marriage. The Enacting Jurisdictions include Connecticut, Delaware, District of Columbia, Hawaii, Illinois, Maryland, Minnesota, New Hampshire, New York, Rhode Island, Vermont, and Washington. For the enacting legislation, see infra Table A1. 
protections for religious organizations and helped pull the legislation over the finish line $\ldots{ }^{23}$

For some legislators, religious liberty protections shifted the question from whether to embrace marriage equality to how to balance marriage equality and religious liberty. For example, New Hampshire State Representative Rick Watrous explained:

[Religious liberty protections] were very important. As you can see by the closeness of the vote, I think it was the crucial difference that made success. . . . These types of very personal and religious freedoms are very important to New Hampshire. ${ }^{24}$

In many Enacting Jurisdictions, more robust protections resulted in successful legislation where a bill with thinner or nonexistent ones had failed just years before..$^{25}$

In fact, every single bill over a decade that has offered hollow religious liberty "protections" limited only to the clergy, who simply do not require protection, ${ }^{26}$ has failed to garner sufficient support to become law. ${ }^{27}$ This remains true after the Supreme Court's decisions. ${ }^{28}$

One would expect legislation with enlarged protections to succeed because legislators inherently balance competing interests in a

23. Danny Hakim, Exemptions Were Key to Vote on Gay Marriage, N.Y. Times, June 26, 2011, at A20.

24. Telephone Interview by Anthony Kreis with Rick Watrous, N.H. State Representative (June 29, 2012). See Kreis \& Wilson, supra note 21.

25. See Kreis \& Wilson, supra note 21 (drawing on interviews with state legislators intimately involved in legislative battles to show that expanded and honed religious liberty protections allowed for same-sex marriage in states like Maryland and New York, where earlier bills had failed).

26. The clergy do not need statutory protections because of the First Amendment. See John Corvino, The Slippery Slope of Religious Exemptions (Nov. 22, 2009), http://johncorvino.com/2009/11/theslippery-slope-of-religious-exemptions/ ("[T]he gay-rights debate concerning religious accommodation is not about worship. No serious person argues that the government should force religions to perform gay weddings (or ordinations or baptisms or other religious functions) against their will. That would violate the First Amendment, and beyond that, it would be foolish and wrong.").

27. See infra Part I.

28. See Kreis \& Wilson, supra note 21. The religious liberty protections may be thinning, however. See infra notes 35-36 (discussing efforts by samesex marriage advocates in Hawaii to provide a stripped-down exemption for religious organizations that was ultimately enlarged by the legislature). For a comparison of the religious liberty protections enacted in Hawaii with those put in place by earlier Enacting Jurisdictions, see Table A3. 
pluralistic, democratic society. ${ }^{29}$ The many clashes over same-sex marriage have highlighted, for some legislators, the need to insulate religious organizations from unintended consequences. ${ }^{30}$ In the words of Washington State Senator Mary Margaret Haugen:

Once I made the decision [to support same-sex marriage], I felt very strongly that those provisions [protecting religious liberty] needed to be there. We have many wonderful organizations. We need to respect each other's space. We need to treat and respect others like we want to treat ourselves. ${ }^{31}$

Even though same-sex marriage recognition in the Enacting Jurisdictions has thus far been yoked to religious liberty protectionsdelivering important gains to supporters and opponents alikeprominent voices on each side now caution against compromise.

Buoyed by their recent victories, some supporters have hardened against compromise. Some supporters have long said that religious liberty protections are "politically unwise." ${ }^{32}$ Now, with a spate of judicial decisions, compromise may appear increasingly unnecessary,

29. The first openly gay legislator to vote against same-sex marriage, Hawaii Representative Jo Jordan, was guided by one question: "[A]re we creating a measure that meets the needs of all?" Diane Lee, Exclusive: Why Rep. Jo Jordan Voted Against Marriage Equality, Honolulu Magazine (Nov. 2013), http://www.honolulumagazine.com/HonoluluMagazine/November-2013/Exclusive-Why-Rep-Jo-Jordan-voted-againstMarriage-Equality/. Representative Jordan explained that she was "really . . . not happy with the exemptions. Too narrow. I'm not here to protect the big churches or the little churches, I'm saying we can't erode what's currently out there. We don't want to scratch at the religious protections at all." Id.

30. See infra Part I for a discussion of the loss of government contracts by religious organizations. See infra note 128 for discussion of a small business facing penalty for a refusal to celebrate same-sex marriage. See infra Part I for a discussion of how justices of the peace, judges, and government clerks may face firing or other penalty for not providing services for a same-sex marriage even if other willing individuals are immediately available to provide the needed service. Although somewhat dated, see Marc Stern, Same-Sex Marriage and the Churches, in Same-SeX Marriage And Religious Liberty: Emerging Conflicts 1 (Douglas Laycock, Anthony R. Picarello, Jr. \& Robin Fretwell Wilson, eds., 2008) [hereinafter Emerging Conflicts] for a discussion of conflicts between religious liberty and same-sex marriage.

31. See Kreis \& Wilson, supra note 21; Telephone Interview by Anthony Kreis with Mary Margaret Haugen, Wash. State Senator (July 16, 2012).

32. Jana Singer, Balancing Away Marriage Equality, SCOTUSblog (Aug. 29, 2011, 1:00 PM), http://www.scotusblog.com/2011/08/balancing-awaymarriage-equality/ (arguing for same-sex marriage legislation stripped of any protections for religious organizations or individuals). 
too. For example, after Garden State Equality v. Dow, ${ }^{33}$ Senate Democrats in New Jersey initially supported and then declined to back state legislation that would have codified same-sex marriage, explaining that the influential same-sex marriage advocate Lambda Legal didn't "want any kind of religious exemption." ${ }^{34}$

In Hawaii, where same-sex marriage resulted from legislation rather than judicial decision, some advocates downplayed religious liberty concerns. They argued strenuously that:

[t]he proposed marriage equality law ensures that no clergy can be required to perform any marriage to which they object. This protects religious freedom. And the law goes further, by clarifying that churches or other religious organizations need not allow anyone to use their facilities for weddings, so long as those facilities aren't rented for weddings to the general public for a profit. ${ }^{35}$

Believing that a broader exemption was needed, the Hawaii legislature approved slightly more robust protection for religious nonprofit organizations. ${ }^{36}$

Opponents are hardening in their stance, too. Far from folding in the face of the momentum carrying same-sex marriage across the country, some thought-leaders urge opponents to double down on their opposition. They say that the "the preservation of meaningful religious liberty ... is inseparable from the preservation of . . . [heterosexual] marriage. They stand or fall together." ${ }^{\prime 37}$ In the Enacting Jurisdictions, they contend that bargaining has "gotten exactly nowhere." 38 That is, efforts to shield religious objectors "have

33. 82 A.3d 336 (N.J. Super. Ct. Law Div. 2013).

34. Ken Klukowski, NJ Stalls Same-Sex Marriage Bill To Kill Religious Protections, Breitbart (Dec. 18, 2013), http://www.breitbart.com /Big-Government/2013/12/18/War-on-Christians-in-New-Jersey

("Democratic Senate Majority Leader Loretta Weinberg pulled the bill that she was supporting because of objections from gay-rights organizations such as Lambda Legal. The reason? Weinberg explained, 'They don't want any kind of religious exemption, so out of respect for that, I will [pull the bill] (emphasis added).'"); see also infra note 63.

35. Hawail Facts on Marriage: Telling the Truth About MARRIAGE EquALITY IN HAwAII, http://www.factsonmarriage.com/ (last accessed Feb. 22, 2014).

36. See infra Table A3.

37. Matthew J. Franck, Same-Sex Marriage and Religious Freedom, Fundamentally at Odds, Public Discourse (June 18, 2013), http://www.thepublicdiscourse.com/2013/06/10393/.

38. Id. ("When the above-mentioned religious liberty scholars have pleaded for accommodation of such persons and groups, they have gotten exactly nowhere. It seems that for same-sex marriage proponents, the religious 
signally [sic] failed to achieve much, if any, meaningful accommodation of religious freedom in the recent legislative enactments of same-sex marriage in New York, Minnesota, Rhode Island, and Delaware." ${ }^{39}$

These opponents see only one way forward: fighting to the bitter end. As one commentator encapsulates this position:

[T]hey have to win this battle entirely or be crushed everywhere, as segregationists were, and for the same reason: their views will be deemed too abhorrent to be tolerated. On this view, preserving religious liberty cannot be separated from preserving traditional marriage. ${ }^{40}$

This Article contends that we stand at a critical moment in the samesex marriage movement. On both sides, some perceive that the delicate state of affairs that has thus far yoked enactment of same-sex marriage to protection of religious liberty is dissipating. However, a clear-eyed examination of the marriage movement's success - and the challenges facing it going forward - reveals that both sides will benefit from remaining at the bargaining table, although the gains for each will be different.

Marriage equality advocates have exhausted those jurisdictions in which a "perfect storm" of popular support, political characteristics, and background legal protections coalesced to yield marriage equality. As advocates move to more difficult political terrain, trading religious liberty protections will remain essential to securing marriage equality, at least in the near term, ${ }^{41}$ since it is unclear whether and when the U.S. Supreme Court will weigh in. On the other side, opponents rightfully worry about the existing scope and degree of protections for religious dissenters. But as the movement moves to more difficult political terrain, opponents will be in a considerably stronger position to get more robust protections. The price tag for those protections, however, will be to agree to recognition of same-sex marriage on the merits.

freedom of saying 'no' to same-sex weddings belongs only to 'religious organizations,' not to similarly situated religious persons, despite the obviously personal character of the First Amendment's free exercise of religion." (emphasis in original).

39. Id.

40. Rod Dreher, Does Faith = Hate?: Gay Marriage and Religious Liberty Are Uneasy Bedfellows, Am. Conservative (Oct. 2013), at 12, 15 (attributing this view to Robert George).

41. See infra note 54 and Part V. The near-term benefit of bargaining assumes that judicial decisions from lower courts striking state marriage bans, as in Oklahoma and Utah, are stayed pending ultimate resolution See supra notes $4-5$. 
Part I demonstrates that same-sex marriage has spread across American through three different avenues: judicial decisions, state laws enacting same-sex marriage, and ballot initiatives. One of these avenues, judicial decisions, is fraught with risk for religious dissenters precisely because it leaves no meaningful opportunity for balancing competing goods, namely, marriage equality with religious liberty. Six of the seven states recognizing same-sex marriage by judicial decision gave no new protections to religious objectors. By contrast, the one ballot initiative state and the Enacting Jurisdictions all offer important, if flawed, protections to religious organizations and individuals. Although they could have gone farther, these protections were enhanced over the course of legislative consideration through extensive negotiation.

Parts II and III document that the "perfect storm" of characteristics favoring marriage equality in the Enacting Jurisdictions, together with extensive bargaining around religious liberty, nudged same-sex marriage legislation over the finish line. In every Enacting Jurisdiction except one, a majority of the populace supported same-sex marriage at the time of enactment ${ }^{42}$ - a marked departure from the states that have not recognized same-sex marriage. In virtually all of the Enacting Jurisdictions, Democrats controlled both houses of the legislature, ${ }^{43}$ Democrats held the Governor's office ${ }^{44}$ and the state ranked among the least religious in the U.S..$^{45}$ but among the most educated ${ }^{46}$-all characteristics that political scientists say matter to support for same-sex marriage. ${ }^{47} \mathrm{In}$ every Enacting Jurisdiction, same-sex marriage recognition was

42. Passage of a law may not be assured even when a majority of the public supports it if one chamber of a state's legislature is controlled by legislators strongly opposed to it. Consider the Employment NonDiscrimination Act (ENDA); more than seventy percent of Americans support ENDA, yet U.S. House of Representatives Speaker John Boehner will not permit the bill to receive a vote in the U.S. House of Representatives. Nonetheless, where majority support is lacking, enactment of a law is less likely. See Andrew Gelman, Polls Say ENDA Has Majority Support in Every Congressional District, The Monkey CAGE (Nov. 20, 2013), http://www.washingtonpost.com/blogs/monkeycage/wp/2013/11/20/polls-say-enda-has-majority-support-in-everycongressional-district/.

43. New York is the sole exception, where Republicans controlled the Senate. See infra Table A5.

44. See infra notes 185-186 (discussing Connecticut and Vermont).

45. Eight of the enacting jurisdictions are in the bottom third for religiosity, while the rest are in the middle third. See infra Figure 13.

46. All but Hawaii are in the top third for post-secondary educational attainment. See infra Figure 14.

47. See infra Part III. 
preceded by a statewide law prohibiting discrimination based on sexual orientation. And in no Enacting Jurisdiction did the state constitution enshrine a ban against same-sex marriage. Notwithstanding these favorable conditions, marriage equality bills just barely squeaked over the line to enactment, ${ }^{48}$ helped in part by religious liberty protections. ${ }^{49}$

That advantageous political terrain is now nearly exhausted, as Part IV documents. In the thirty-one states that have not enacted same-sex marriage or recognized it by judicial decision ("Nonrecognizing States"), the characteristics that favored legislative recognition splinter and, in some places, vanish entirely. Where the Enacting Jurisdictions are heavily blue states, the Nonrecognizing States are heavily red states. Republicans occupy the Governor's office in 24 states and control the legislature in twenty-six states, while splitting control in two others. More than $80 \%$ of the Nonrecognizing States rank among the top two-thirds of states for religiosity and the bottom two-thirds for educational attainment. ${ }^{50}$ Only four Nonrecognizing States assure sexual orientation nondiscrimination by state law. ${ }^{51}$ And twenty-seven of the thirty-one Nonrecognizing States ban same-sex marriage in the state's constitution, erecting a significant (but not impossible) hurdle to voluntary same-sex marriage recognition..$^{52}$ Going forward, one would reasonably expect more robust religious liberty protections to play a central part in any legislative compromises over same-sex marriage, at least for the near term.

Part $\mathrm{V}$ evaluates the impulse of some opponents to dig in, resisting same-sex marriage at all costs. It first shows that constitutional amendments banning same-sex marriage do not provide the bulwark against change that some assume. Only a fourth of the constitutional amendment states (seven of the twenty-seven) erect a significant hurdle to removal of the ban. Moreover, while large swaths of the country today show deep resistance to same-sex marriage, public support is mushrooming. Increasing acceptance is fueled by increased familiarity with and acceptance of lesbians and gays by Americans. Public opposition will only recede further as the oldest

48. See infra Table 1 and Part II; Table A5.

49. See infra Part II.

50. See infra Part III and Table A4. Oregon, Alaska, Nevada, Wyoming, Colorado, and Montana all rank in the bottom one-third for religiosity, while Oregon, Virginia, and Colorado rank in the top one-third for postsecondary educational attainment. See infra Figures 18, 19.

51. See infra Figure 20 (showing Oregon, Nevada, Colorado, and Wisconsin).

52. See infra Figure 21 (showing that Wyoming, Indiana, West Virginia, and Pennsylvania do not ban same-sex marriage in the constitution). 
generation passes on. ${ }^{53}$ Thus, "[t]ime is on the gay-rights side." ${ }^{54}$ At some point, public support will swamp those characteristics that augur against same-sex marriage recognition, making enactment of same-sex marriage in the absence of religious liberty protections possible - at least in the 20 states where state constitutions can be readily amended..$^{55}$ One should not overlook the fact that court decisions striking bans under the federal constitution have already occurred in red states, creating yet more urgency to compromise now. ${ }^{56}$

Part VI concludes that, in the tougher political terrain that looms, those who care about marriage equality can continue to sew up legislative victories - but the price tag in the short term will be to agree to robust religious liberty protections for dissenters. ${ }^{57}$ Concededly, many believe that the early judicial decisions striking down marriage bans portend a favorable Supreme Court decision in the near term. Although that result is increasingly likely, it is nonetheless not assured. Moreover, if the lower federal courts uniformly strike down marriage bans, that success in the courts may, ironically, delay ultimate resolution by the Supreme Court, which often declines review until a meaningful circuit split arises. ${ }^{58}$ Thus, marriage equality supporters continue to gain from the voluntary embrace of same-sex marriage.

The case for bargaining is even stronger for marriage equality opponents. Those who wish to protect religious objectors from the unintended consequences of same-sex marriage should act with all

53. See infra Part II and Figs. 6-10; but compare note 156 (discussing Rice University study).

54. Dreher, supra note 40. See infra Parts II and V.

55. See infra Part I. See also Rachel Zoll, Divide over Religious Exemptions on Gay Marriage, AP, Aug. 25, 2013, http://bigstory.ap.org/article/ divide-over-religious-exemptions-gay-marriage (quoting Douglas Laycock, a "church-state expert" from the University of Virginia who is recommending a more pragmatic course, as stating that "The more same-sex marriage seems inevitable, the less likely we are to see religious liberty protection in blue states").

56. See supra Part V (discussing the deeply red character of Oklahoma and Utah, where court decisions striking state constitutional bans are presently stayed).

57. See Zoll, supra note 55 (quoting Douglas Laycock as stating that, "The religious community would have done much better to ask for protection for their religious liberty instead of trying to stop same-sex marriage and try to prevent it for everybody ....").

58. Emily Grant, Scott A. Hendrickson, \& Michael S. Lynch, The Ideological Divide: Conflict and the Supreme Court's Certiorari Decision, available at http://papers.ssrn.com/sol3/papers.cfm?abstract _id $=2138211 \&$ download $=$ yes. 
deliberate speed to lock in robust religious liberty protections because the window for securing them is almost certainly closing. But that window will not, as some predict, slam shut if the U.S. Supreme Court recognizes same-sex marriage as a federal constitutional right in 2015 or later. The same factors that make the legislative terrain going forward difficult suggest that red states will be able to enact religious liberty protections, if for no other reasons than they will have the naked power to do so. And even after this point, same-sex marriage opponents will still have some bargaining leverage if they are willing to provide a promise of non-discrimination based on sexual orientation as the quid pro quo for religious liberty protections.

This focus on the pragmatic value of bargaining should not detract from principled arguments favoring a live-and-let-live regime that both respects marriage equality and religious diversity. The same fundamental values of personal liberty that support an individual's right to live according to his or her religious convictions also support an individual's right to follow and fulfill his or her essential identity, including sexual identity and same-sex relationships. ${ }^{59}$

\section{The Importance of Bargaining Before JUDICIAL ACTION}

Same-sex marriage opponents are running a race against time. As Parts II and III will show, in the next decade, swelling public support for same-sex marriage will swallow nearly all opposition to enacting it. This will likely eliminate, in the not too distant future, the need for supporters to bargain around religious liberty and same-sex marriage.$^{60}$ The more immediate threat to the opportunity to seek

59. Professor Chai Feldblum (now a Commissioner for the U.S. Equal Employment Opportunity Commission) argues that the "identity liberty" same-sex couples have in marriage and the "belief liberty" objectors have in their religious tenets are both fundamental values that deserve protection, however, these values can come into direct conflict when civil rights laws require one to accommodate the other. See Chai R. Feldblum, Moral Conflict and Conflicting Liberties, in EMERGING Conflicts, supra note 30, at 123, 157. Professor Feldblum concludes that the demand of civil rights laws "can burden an individual's belief liberty interest" but that "[a]cknowledging [the burden's impact] . . . does not necessarily mean that [civil rights] laws will be invalidated or that exemptions ... will always be granted to individuals holding such beliefs." Id. at 125; see also Thomas C. Berg, What Same-Sex Marriage and Religious-Liberty Claims Have in Common, 5 Nw. J. L. \& Soc. POL'Y 206, 219-20, 230-32 (2010) (engaging Feldblum's argument); see also Douglas Laycock \& Thomas C. Berg, Protecting Same-Sex Marriage and Religious Liberty, 99 VA. L. REV., IN BRIEF 1 (2013) (noting that religious freedom and marriage equality both seek to protect minorities that have been historically oppressed).

60. See infra Parts II and III. Mushrooming public support may lead not to just successful enactment of marriage equality legislation, but to voter 
compromise is a judicial decision by a state or federal court authorizing same-sex marriage. While the U.S. Supreme Court could resolve the federal constitutional entitlement to same-sex marriage decisively, ${ }^{61}$ it is unlikely to do so until a meaningful circuit split arises and even then, not before 2015 at the earliest. ${ }^{62}$ Experience

led ballot initiatives as well. It is instructive that Maine, the only state to enact same-sex marriage by popular referendum to date, included tangible protections of dissenting religious organizations. See infra Table A1. Nonetheless, it is not at all clear that a ballot initiate will include adequately developed religious liberty protections. See infra Table A3. The absence of direct input of religious liberty scholars (to my knowledge), and the fact that (a) sponsors do not conduct hearings as legislators do, (b) interested parties do not have the opportunity with ballot sponsors to enlarge protections with specific constituents in mind (e.g., religiously affiliated social services agencies, like Catholic Charities), and (c) protections are not improved across the legislative cycle all auger against meaningful protections. See infra Parts II and III.

61. Constitutional challenges to marriage restrictions proceeded early on as challenges under state constitutional guarantees, while later challenges have now been brought under the U.S. Constitution as well. Compare Kerrigan v. Comm'r of Pub. Health, 957 A.2d 407 (Conn. 2008) (holding that the Connecticut's state constitution was violated by restricting marriage to heterosexual couples), and Goodridge v. Dep't of Pub. Health, 798 N.E.2d 941 (Mass. 2003) (holding that limitations for the protections of same-sex individuals violated Massachusetts' state constitution), with Bishop v. United States ex rel. Holder, No. 04-CV-848-TCK-TLW, 2014 WL 116013, at ${ }^{*} 33$ (N.D. Okla. Jan. 14, 2014) (holding that Oklahoma's amendment prohibiting same-sex marriage violated the U.S. constitution), and Kitchen v. Herbert, No. 2:13-cv-217, 2013 WL 6697874, at *30 (D. Utah Dec. 20, 2013) (holding that Utah's amendment prohibiting same-sex marriage violated the U.S. constitution). Dean Erwin Chemerinsky believes that early constitutional challenges under state constitutional guarantees delivered important, early judicial wins to advocates, without the threat of a federal court of appeals or Supreme Court decision going the other way. See Erwin Chemerinsky, Keynote at the U.C. Davis Law Review Symposium, Not Equal Yet: Building Upon Foundations of Relationship Equality (Feb. 7, 2014). A decision from a U.S. Circuit Court of Appeals under federal constitutional guarantees would answer the question dispositively in that circuit, absent a contrary ruling from the U.S. Supreme Court. For example, a decision in the 10th Circuit would encompass Colorado, Kansas, New Mexico, Oklahoma, Utah, and Wyoming.

62. See supra note 58 (discussing the importance of circuit splits to Supreme Court decisions to grant review); Liptak, supra note 11 ("Whatever the Supreme Court does regarding a stay, it is hard to see how it could hear the larger issue in the case in the current term. But a decision in the court's next term, culminating in a decision in June 2015, is entirely possible."). For a discussion of avoiding unintended consequences on bargaining of a Supreme Court decision, see Robin Fretwell Wilson and Anthony Kreis, Balancing marriage equality with other social goods, SCOTUSBlog (Aug. 22, 2011), http://www.scotusblog.com/ 2011/08/balancing-marriage-equality-with-other-social-goods/ ("But if the Supreme Court does weigh in here, an unintended consequence of its 
shows, however, that a state-specific judicial decision removes the urgency to bargain in order to secure legislative recognition of samesex marriage in that state. ${ }^{63}$

decision may be to strangle the delicate process unfolding in state legislatures across the country by changing the political calculus for granting robust accommodations. If the Court recognizes a federal constitutional right to same-sex marriage, it should take care to leave a space for individual states to continue to decide how best to balance marriage equality with other goods in society."); see also Douglas Laycock \& Thomas C. Berg, Protecting Same-Sex Marriage and Religious Liberty, 99 VA. L. REV., IN BRIEF 1 (2013) (arguing that if the Court recognizes same-sex marriage (as they argue it should), it should expressly endorse religious liberty protections); Douglas Laycock \& Thomas C. Berg, Brief Amicus Curiae of the American Jewish Committee in Support of the Individual Respondents on the MERITS (2013), available at http://sblog.s3.amazonaws.com/wpcontent/uploads/2013/03/Marriage-Cases-AJC-Brief-Final.pdf.

Some believe that if the Court constitutionally recognizes same-sex marriage, religious objectors will be in the place of asking for concessions because "now they are the ones who are the outliers hoping to be accommodated." See Steven D. Smith, Die and Let Live? The Asymmetry of Accommodation (manuscript at 10) (forthcoming 2014), available at http://papers.ssrn.com/sol3/papers.cfm?abstract_id= 2484801. As Part V explains, the more challenging terrain facing marriage equality advocates going forward will place a premium on granting religious liberty protections even after a Supreme Court decision. In the perfect world, those protections would be tied to mutual benefit to the lesbian, gay, bisexual, and transgender (LGBT) community, like a promise of nondiscrimination in state law.

63. A judicial decision recognizing same-sex marriage means that advocates need not bargain around religious liberty protections in order to achieve marriage equality. After a judicial decision, legislators may resist codifying legislation, worried that including religious liberty protections may be seen as chipping away at the broader right established by the court. See infra Part II. That dynamic is seen most vividly in New Jersey.

In October 2013, New Jersey joined those states recognizing same-sex marriage by judicial intervention. See Garden State Equality v. Dow, 82 A.3d 336 (N.J. Super. Ct. Law Div. 2013) (permitting same-sex marriage in New Jersey). Three weeks later, state officials dropped the state's appeal of the decision. See Dismissal of Appeal, App Div. Doc. No. A0521-13 (N.J. Super. Ct. Law Div. Oct. 21, 2013), available at: http://www.judiciary.state.nj.us/samesex/AG\%20Withdrawal\%20of\%20A ppeal\%20102113.pdf. Only 8 months before, Governor Christie vetoed a 2012 same-sex marriage bill that contained modest religious liberty protection for organizations. See Kate Zernike, Christie Keeps His Promise to Veto Gay Marriage Bill, N.Y. TIMES, Feb. 18, 2012, at A19. The provision would have protected religious institutions against civil suit or government penalty for refusing to "provide space, services, advantages, goods, or privileges related to the solemnization, celebration or promotion of marriage if such solemnization, celebration or promotion of marriage is in violation of the beliefs of such religious society, institution or organization." S.B.1, 215th Leg. (N.J. 2012) (enacted). 
As Figure 1 shows, state and federal courts are handing down judicial decisions more readily after Windsor ${ }^{64}$ As of this writing, seven states ${ }^{65}$ (California, ${ }^{66}$ Iowa,${ }^{67}$ Massachusetts, ${ }^{68}$ New Jersey, ${ }^{69}$ New Mexico, ${ }^{70}$ Oklahoma, ${ }^{71}$ and $\mathrm{Utah}^{72}$ ) have recognized same-sex marriage by judicial decision ("Judicial Decision States").

In the weeks after Garden State Equality v. Dow, legislators considered whether to override the Governor's veto, which would have placed that modest religious liberty protection into law. When the window for overriding the governor's veto closed, Senators Loretta Weinberg and Raymond J. Lesniak introduced Senate Bill 3109 on December 12, 2013 to "codify the ruling . . . in Garden State Equality v. Dow." S.B. 3109, 215th Leg. (N.J. 2013) (enacted), available at http://www.njleg.state.nj.us/2012 /Bills/S3500/3109_I1.PDF. Intending to "leave decisions about religious marriage to religions, and to uphold the free exercise of religion," SB 3109 included a limited exemption for religious organization identical to the one that Governor Christie vetoed. As noted in the Introduction, Weinberg, under pressure from same-sex marriage advocates, withdrew the bill.

Of course, this could have unfolded differently, as it did in Connecticut where the legislature followed on the heels of a same-sex marriage decision with legislation codifying the result and protecting religious liberty. See infra note 66 and Table A1.

64. As of Jan. 16, 2014, there have been four decisions recognizing same-sex marriage since Windsor, in New Jersey, New Mexico, Utah, and Oklahoma. See cases cited supra note 8.

65. In addition to these seven Judicial Decision States, same-sex marriage was also originally recognized in Connecticut by judicial decision. See Kerrigan v. Comm'r of Pub. Health, 957 A.2d 407 (Conn. 2008) (concluding that the state statutory scheme impermissibly discriminated against gay persons). However, Connecticut is not treated here as a Judicial Decision State because the state enacted same-sex marriage legislation following the Kerrigan decision. See infra note 91 and Table A1.

66. See Hollingsworth v. Perry, 133 S. Ct. 2652, 2668 (2013) (holding in June 2013 that private parties lacked standing to appeal lower court decisions finding unconstitutional California's state constitutional samesex marriage ban, permitting California to resume same-sex marriages).

67. See Varnum v. Brien, 763 N.W.2d 862, 906 (Iowa 2009) (holding that the Iowa marriage statute limiting marriage to one man and one woman violated the equal protection clause of the Iowa Constitution).

68. See Goodridge v. Dep't of Pub. Health, 798 N.E.2d 941 (Mass. 2003) (holding that barring an individual from civil marriage simply because the person will marry someone of the same sex violated the Massachusetts Constitution).

69. See Garden State Equality v. Dow, 82 A.2d 336 (N.J. Super. Ct. Law Div. 2013) (striking down New Jersey's civil union statute, which provided the only relationship recognition for same-sex couples, as violative of the New Jersey Constitution and requiring the state to permit same-sex couples to marry).

70. See Griego v. Oliver, 316 P.3d 865 (N.M. 2013) (authorizing same-sex marriage in New Mexico). 
Same-sex marriage by judicial decision alone is the real "nightmare for religious liberty" that opponents fear. ${ }^{73}$ As Figure 2 shows, judicial decisions leave religious objectors the most exposed. ${ }^{74}$

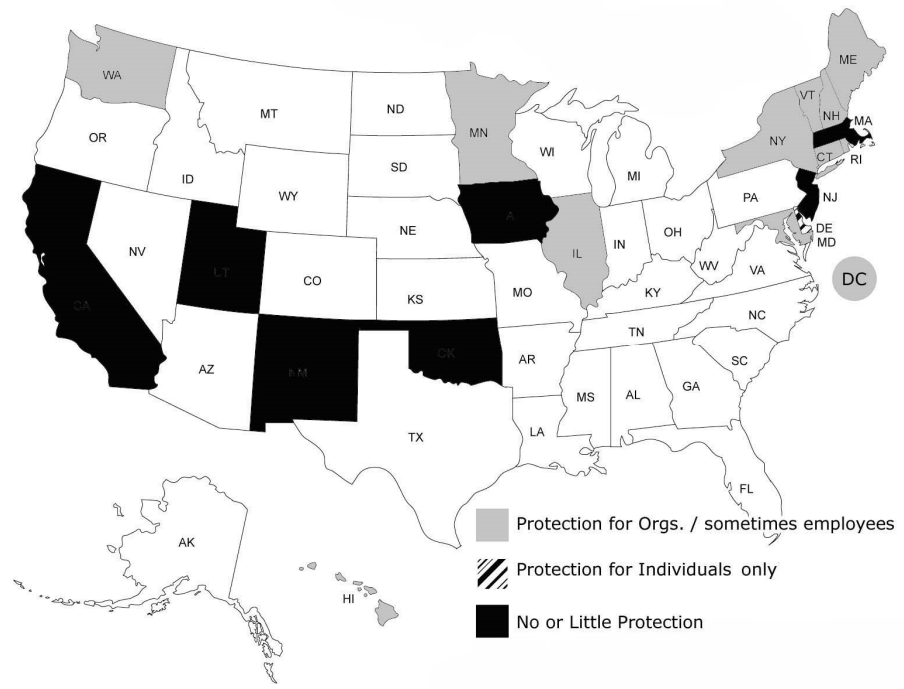

Figure 2: Degrees of Protection in Same-Sex Marriage States

Six of the seven Judicial Decision States give no protection to religious objectors that objectors did not already have prior to the

71. See Bishop v. United States ex rel. Holder, No. 04-CV-848-TCK-TLW, 2014 WL 116013, at *33 (N.D. Okla. Jan. 14, 2014) (declaring that the Oklahoma constitutional Amendment precluding same-sex couples from receiving a marriage license violates the Fourteenth Amendment to the U.S. Constitution).

72. See Kitchen v. Herbert, No. 2:13-cv-217, 2013 WL 6697874, at *30 (D. Utah Dec. 20, 2013) (declaring that the amendment to the Utah constitution violated the Fourteenth Amendment of the U.S. Constitution).

73. Ryan T. Anderson, In Illinois, Redefining Marriage Threatens Marriage and Religious Freedom, THE FOUNDRY, (Jan. 4, 2013, 1:16 PM), http://blog.heritage.org/2013/01/04/in-illinois-redefining-marriagethreatens-marriage-and-religious-freedom/ ("As my Heritage Foundation colleague Tom Messner has documented again, and again, and again, redefining marriage has already been - and will continue to be - a nightmare for religious liberty.").

74. After state courts in Iowa and Massachusetts held that their respective state constitutions required the recognition of same-sex marriages, the state legislatures did not revisit preexisting nondiscrimination law. See Zoll, supra note 55 ("Massachusetts and Iowa, where same-sex marriage won recognition through the courts, have approved no enhanced religious exemptions related to the rulings."). California's legislature enacted minimal protections as litigation over Prop 8 worked its way through the courts, resulting in the Hollingsworth decision. See infra Tables A1 and A3. 
decisions (Iowa, Massachusetts, New Jersey, New Mexico, Oklahoma, and Utah). ${ }^{75}$ The one Judicial Decision State that does give new statutory protections specific to marriage, California, did so by legislation, as noted below. The failure of the judiciary to protect religious objectors is hardly that fault of the courts. Courts lack the inherent ability of legislatures to conduct hearings and take testimony about how to balance competing goods in a plural society. Moreover, protecting religious objectors is not the issue presented in cases establishing a right to same-sex marriage.

Contrast this with the Enacting Jurisdictions. The Enacting Jurisdictions placed into law statutory protections specific to marriage $^{76}$ that, while imperfect, generally insulate religiously

75. Some same-sex marriage decisions acknowledge the possibility of an impact on something other than solemnization of the marriage itself. See, e.g., Griego v. Oliver, 316 P.3d 865 (N.M. 2013) ("Our holding will not interfere with the religious freedom of religious organizations or clergy because (1) no religious organization will have to change its policies to accommodate same-gender couples, and (2) no religious clergy will be required to solemnize a marriage in contravention of his or her religious beliefs." (emphasis added)). Griego cites N.M. StAT. AnN. $\S 28-1-9(B) \quad \& \quad$ (C) (1978 \& Supp. 2012), which exempts religious organizations from the New Mexico Human Rights Act, to support its holding. But judicial decisions have not, and cannot, provide the kind of protection for religious dissenters that have been forthcoming from state legislatures.

Religious objectors may or may not receive protection from the state's background nondiscrimination laws. For example, while Iowa's background law insulates religious organizations when hiring for a "bona fide religious purpose," Massachusetts' public accommodation statute provides no express protection for religious organizations. IOWA CODE AnN § 216.7 (West 2013); see Mass. Gen. LaWs Ann. ch. 272, § 92A (West 2000) (defining a public accommodation). The Massachusetts Supreme Judicial Court has interpreted the Massachusetts Constitution to require the application of strict scrutiny to free exercise claims. See Attorney Gen. v. Desilets, 636 N.E.2d 233, 236 (1994) (rejecting the Dep't of Human Resources of Or. v. Smith, 494 U.S. 872 (1990), standard for free exercise claims under the Massachusetts Constitution and applying strict scrutiny). State Religious Freedom Restoration Acts (RFRAs) in the Judicial Decision States may provide some protection. See N.M. Stat. §§28-22-1 to 28-22-5 (2006); Okla. Stat. Ann. tit. 51, $\S \S 251-258$ (West 2010). The federal and state RFRAs all "facially require strict scrutiny of all substantial burdens on religious practices." Eugene Volokh, Intermediate Questions of Religious Exemptions-A Research Agenda with Test Suites, 21 CARdozo L. Rev. 595, 598 (1999) (arguing that while "RFRAs have more specific, binding text than does the Free Exercise Clause," they leave open a number of questions). See also Christopher C. Lund, Religious Liberty After Gonzales: A Look at State RFRAs, 55 S.D. L. REV. 466 (2010).

76. Religious objectors may receive some protection from the state's background laws. In three Enacting Jurisdictions, a state RFRA, modeled on the federal RFRA, is also in place. See Conn. Gen. Stat. 
affiliated nonprofits from private suit and government penalty for refusing to solemnize or celebrate a marriage if doing so would violate their religious beliefs, as Table A3 shows. ${ }^{77}$ Protections, especially for religious nonprofits, are crucial because religious groups have faced both lawsuits and penalty by the government. For example, the Salvation Army lost $\$ 3.5$ million in social service contracts with the City of San Francisco because it refused, on religious grounds, to provide benefits to its employees' same-sex partners. ${ }^{78}$ In Maine, Catholic Charities lost access to municipal development funds for similar reasons. ${ }^{79}$ In New Jersey, a Methodist nonprofit association violated New Jersey's law against discrimination when the nonprofit

Ann. §52-571b (West 2009); 775 Ill. Comp. Stat. Ann. 35/1-99 (West 2009); R.I. GEN. LAws §§42-80.1-1 to -4 (2006). In addition, three Enacting Jurisdictions (Maine, Minnesota, and Washington) have interpreted their state constitutions to protect against neutral and generally applicable laws that substantially burden religious belief or practice. See First Covenant Church v. City of Seattle, 840 P.2d 174 (Wash. 1992); Cooper v. French, 460 N.W.2d 2 (Minn. 1990); Rupert v. City of Portland, 605 A.2d 63 (Me. 1992). These generalized protections may or may not provide anything more than the statutory protections specific to marriage. But they are there, and people can invoke them in the marriage context.

Finally, the anti-discrimination law in several Enacting Jurisdictions give modest protection to religious organizations. See Minn. Stat. ANN. § 363A.26 (West) (2012) (providing accommodation to religious associations in matters relating "to sexual orientation, [when] taking any action with respect to education, employment, housing and real property, or use of facilities"); Md. Code Ann., Md. State Gov'T $\S 20-604(2)$ (2011) (prohibiting discrimination in employment but exempting religious organizations); N.Y. ExEC. LAW § 11 (2011) (providing religious liberty accommodations for rental and housing in discrimination ban). In some cases, however, these laws provide little sanctuary for objectors.

77. See Conn. Gen. Stat. § 45b-35a (Supp. 2013); D.C. Code § 46-406(e) (LexisNexis 2012); Md. H.B. 438 §§ 2-3 (West 2012) (codified as MD. Code Ann., Fam. Law $\S \S 2-201,2-202$ (2012)); Minn. Stat. Ann. $\S 517.09$ (West 2013); N.H. Rev. Stat. AnN. § 457:37(III) (West 2004); N.Y. Dom. Rel. LaW § 10-b(1) (McKinney Supp. 2014); R.I. Gen. LaWS AnN. § 15-3-6.1 (LexisNexis 2013); VT. Stat. AnN. tit. 8, § 4502(1) (2012); Wash. Rev. Code $\S$ 26.04.010(6) (West 2012). See also infra Table A3.

78. See Manny Fernandez \& April Lynch, Salvation Army Cuts S.F. Programs: Charity Spurns City's Domestic Partner Law, S.F. Chronicle, June 4, 1998, at A1, A15 (providing details on the cuts to the Salvation Army in San Francisco for refusing to provide same-sex benefits for employees).

79. See Catholic Charities of Maine, Inc. v. City of Portland, 304 F. Supp. 2d 77 (D. Me. 2004) (upholding ordinance requiring religious charity to either extend employee spousal benefit programs to registered same-sex couples, or to lose eligibility for all city housing and community development funds). 
association denied two same-sex couples' requests to use the group's boardwalk pavilion for their civil union commitment ceremonies. ${ }^{80}$

In many Enacting Jurisdictions, religious individuals, universities, social services agencies, and fraternal organizations receive protections, as well. ${ }^{81}$ As Table A3 shows:

- Four jurisdictions allow the Knights of Columbus or other religious organizations to continue to offer an insurance product for spouses in heterosexual marriages (Vermont, New Hampshire, Maryland, and Rhode Island).

- Five jurisdictions expressly say religious organizations need not promote same-sex marriage through religious counseling or retreats (Maryland, DC, New Hampshire, Rhode Island, and Washington). Three extend this to married-couple housing (Minnesota, New Hampshire, and New York).

- Four jurisdictions allow religiously affiliated adoption agencies to continue to place children only with heterosexual married couples (Connecticut, Maryland, Minnesota, and Rhode Island); three condition the exemption on not receiving government funding for the program (Connecticut, Maryland, and Minnesota).

- Six states expressly exempt individual employees of a covered entity from celebrating or promoting same-sex marriageswhile it is hard to imagine who this protects, think of a lawsuit filed against a church employee, instead of suing the church (Maryland, Minnesota, New Hampshire, New York, Rhode Island, and Washington). ${ }^{82}$

80. See Bernstein v. Ocean Grove Camp Meeting Ass'n, OAL DKT. CRT 6145-09, 2012 WL 169302, at *1, 2 (N.J. Adm., Jan. 12, 2012) ("The Green Acres program is designed to preserve open space and the statutory scheme authorizes a tax exemption for non-profit corporations utilizing property for conservation or recreational purposes. One condition of the exemption is that the property be 'open for public use on an equal basis."'); see also Barbara Bradley Hagerty, Gay Rights, Religious Liberties: A Three-Act Story, NPR (June 16, 2008, 12:12 AM), http://www.npr.org/templates/story/story.php?storyId=91486340. The group also lost its exemption from ad volorem property taxes on the pavilion, but that loss was hastened by the group's own decision to tie its property tax exemption to a public lands program. Although the loss of a tax exemption expressly conditioned upon "public access" to a parcel of land hardly seems unfair, see Kreis \& Wilson, supra note 21, tax-exempt religious groups fear that they may lose valuable benefits if their views of marriage become "disfavored."

81. See infra Table A3; see also infra Part II for a discussion of the extent of protection for religious objectors in state same-sex marriage laws.

82. See Md. H.B. $438 \S \S 2-3($ b) (codified as Md. Code Ann., Fam. Law $\S \S 2-201,2-202$ (LexisNexis 2012); Minn. Stat. Ann. § 517.09(3)(b) 
- Six states specifically carry forward religious liberty protections present in the underlying anti-discrimination statute or state Religious Freedom Restoration Act (Delaware, Illinois, Minnesota, New York, New Hampshire, and Rhode Island) ${ }^{83}$

- One state, Delaware, permits justices of the peace and judges to choose to solemnize only those marriages they choose to. ${ }^{84}$

Until Delaware, no jurisdiction had provided protection to government officials. Where protections are lacking, justices of the

(West Supp. 2013); N.H. Rev. Stat. Ann. § 457:37(III); N.Y. Dom. Rel. Law. § 10-b (1); R.I. Gen. Laws Ann. § 15-3-6.1(c)(2)(e) (LexisNexis 2013); Wash. Rev. Code $\S 7(\mathrm{a})(\mathrm{i})$.

83. Legislation in Delaware, Illinois, Minnesota, New York, New Hampshire, and Rhode Island also contained "catch-all" protections, carrying forward existing preexisting exemptions in each state's underlying statutory scheme barring discrimination. See N.H. REv. StAT. AnN. § 457:37 (West 2004) ("Nothing in this chapter shall be deemed or construed to limit the protections and exemptions provided to religious organizations under RSA 354-A:18."); SF 925, 88th Legis. Reg. Sess. (Minn. 2013) ("This chapter does not alter or affect the protections or exemptions provided in chapter $363 \mathrm{~A}$ for a religious association, educational institution, business, labor organization, place of public accommodation, employer, or other person."); SB 10, 98th Gen. Assm. Reg. Sess. (Ill. 2013) ("Nothing in this Act is intended to abrogate, limit, or expand . . . the Illinois Human Rights Act or the Religious Freedom Restoration Act."); 3. N.Y. Dom. Rel. Law § 10-b. ("Nothing in this section shall be deemed or construed to limit the protections and exemptions otherwise provided to religious organizations under section three of article one of the constitution of the state of New York."); R.I. Gen. Laws Ann. § 15-3-6.1 ("Nothing in the marriage laws of this state shall be deemed or construed to limit the protections and exemptions provided to religious organizations under GL paragraph 28-5-6(7)(ii) and subsection 34-37-4.2(a)"). Delaware's law provides that the same-sex marriage law "does not affect rights, duties or obligations that matured or were owed, penalties that were incurred, or proceedings that were begun, before its effective date." Delaware Laws Ch. 19 (H.B. 75 2013); see also Table A3.

For Enacting Jurisdictions with state RFRAs, see supra note 76 (cataloging those Enacting Jurisdictions that had enacted state Religious Freedom Restoration Acts before same-sex marriage). For details of the sexual orientation nondiscrimination laws that preceded same-sex marriage recognition in the Enacting Jurisdictions, see Table A2.

84. See Del. Code Ann. tit. $13 \S 106$ (2013), http://delcode.delaware.gov/ title13/c001/sc01/index.shtml ("[N]othing in this section shall be construed to require any person (including any clergyperson or minister of any religion) authorized to solemnize a marriage to solemnize any marriage, and no such authorized person who fails or refuses for any reason to solemnize a marriage shall be subject to any fine or other penalty for such failure or refusal."). 
peace have been told to "follow the law, whether you like it or not." 85 The Iowa Attorney General told county recorders to effect same-sex marriages or face possible "legal actions" - like firing. ${ }^{86}$ Judges in Iowa were told they have discretion to decide which marriages over which to preside, but they better not use that discretion in a biased way, notwithstanding sincerely held religious convictions. ${ }^{87}$

Religious liberty protections obviously redound to the benefit of people who cannot, consistent with their religious beliefs, celebrate or assist with certain marriages. ${ }^{88}$ Often overlooked is the fact that the

85. Katie Zezima, Obey Same-Sex Marriage Law, Officials Told, N.Y. Times, Apr. 26. 2004, at A15 ("Daniel B. Winslow, chief counsel for Gov. Mitt Romney said ... . If you hold true to your oath of office and follow the law, whether you agree with it or not, you will fulfill your duty as a justice of the peace.' Mr. Winslow urged any justice with qualms about officiating for same-sex couples to resign.").

86. Statement of the Iowa Attorney General Tom Miller, County Recorders must Comply with Supreme Court's Varnum Decision (Apr. 21, 2009), available at http://www.state.ia.us/government/ag/latest_news/ releases/apr_2009/Marrige_Stmnt.html ("We expect duly-elected county recorders to comply with the Iowa Constitution as interpreted unanimously by the Iowa Supreme Court, the highest court in Iowa. Our country lives by and thrives by the rule of law, and the rule of law means we all follow the law as interpreted by our courts - not by ourselves. We don't each get to decide what the law is; that would lead to chaos. We must live by and follow what the courts decide.").

87. See Kilian Melloy, Iowa Magistrate to Stop Performing Marriages, EDGE BOSTON, Apr. 23, 2009, http://www.edgeboston.com/ index.php?ch=news\&sc $=\& s c 2=$ news\&sc $3=\& i d=90310 \quad$ (quoting Bob Brammer, a spokesperson for Iowa's Attorney General's office).

For an argument that protections for officials who can effectively block a couple's access to marriage should be qualified by hardship to samesex couples, see Wilson, The Calculus of Accommodation, at 1480 (criticizing an "exemption for government employees or officialsunqualified by hardship-[as possibly] erect[ing] a roadblock to marriage"); Douglas Laycock, Afterword, in Emerging Conflicts, supra note 30, at 200 (arguing that "[r]eligious dissenters can live their own values, but not if they occupy choke points that empower them to prevent same-sex couples from living their own values. If the dissenters want complete moral autonomy on this issue, they must refrain from occupying such a choke point").

88. For many scholars, it is not enough to just protect religious objectorsthe interests of same-sex couples must also be taken into account. A group of scholars with which I work has argued for qualified exemptions for individuals - that is, an exemption that allows individual religious objectors to step away from facilitating any marriage but only when a hardship will not result for those seeking a service. Religious organizations would be permitted to decline to solemnize or celebrate or facilitate a solemnization or celebration, or to recognize a marriage when doing so would violate the organization's religious tenets, notwithstanding hardship to others. For the current text of the model protection, see Letter from Thomas C. Berg et al., to Hawaii State 
same provisions benefit same-sex marriage advocates because they take a powerful argument away from marriage opponents. ${ }^{89}$ Taken as a whole, these protections extend well beyond the church sanctuary and provide greater protection than what the Supreme Court has said is constitutionally commanded.$^{90}$ Even Maine, the only jurisdiction to recognize same-sex marriage by popular ballot, included some meaningful protections for dissenting religious organizations. ${ }^{91}$ Although the scope and contours of the protection granted by Maine

Senators (May 2, 2013), available at http://mirrorofjustice.blogs. com/files/hawaii-special-session-letter-10-17-13.pdf (providing model religious liberty protections). Under this proposal, the ability to object is not limited to same-sex marriage, but extends to objections for reasons of faith to any marriage - such as interfaith marriages or second marriages. $I d$.

89. See Robin Wilson, Op-Ed, Rhode Island marriage law should shield religious liberty, The Providence J., Feb. 13, 2011, at A19. One prominent gay rights leader, Jonathan Rauch, has pointed out, the smart move is to "bend toward accommodation," not away from it. See Jonathan Rauch, The Majority Report, The Advocate (Nov. 19, 2010, 4:00 AM), http://www.jonathanrauch.com/jrauch_articles/theemerging-gay-majority/ (arguing that gay marriage advocates adopt "two important strategic changes . . . . First, accept legal exceptions that let religious organizations discriminate against gays whenever their doing so imposes a cost we can live with. Second, dial back the accusations of 'bigot' and 'hater' . . . . Not every religious accommodation is valid, and it's not always clear where to draw all the lines. But the smart approach is to bend toward accommodation, not away from it, whenever we can live with the costs.").

90. See Employment Division v. Smith, 494 U.S. 872, 890 (1990) (holding that neutral and generally applicable laws do not violate the First Amendment no matter how much they burden an individual's or organization's exercise of religious liberty), superseded by statute, Religious Freedom Restoration Act, 42 U.S.C. § 2000bb(a)(4) (2006), as recognized in Sossamon v. Texas, 131 S. Ct. 1651 (2011). Whether the Smith decision was correctly decided or represents an improper restraint on free exercise remains a deeply contested question. See, e.g., David B. Frohnmayer, Employment Division v. Smith: "The Sky That Didn't Fall", 32 CARDOZO L. REv. 1655 (2011); Douglas Laycock, The Religious Exemption Debate, 11 Rut. J. L . \& Religion 139, n.44 (2009); Kent Greenawalt, Fighting Words: Individuals, Communities, And Liberties of SpeEch 138 (1995) ("The decision was statist and majoritarian in a virulent form. It was inadequate whether one focuses on individual liberty, church autonomy, or long-term benefit of the polity."). For a discussion of possible challenges to religious liberty protections based on the Establishment Clause, see Robin Fretwell Wilson, Insubstantial Burdens: The Case for Government Employee Exemptions to Same-Sex Marriage Laws, 5 Nw. J. L. \& Soc. PoL'Y 318 (2010).

91. See infra Table A3. 
and the Enacting Jurisdictions vary from state to state, all provide far more insulation than the alternative - a judicial decision alone. ${ }^{92}$

Nothing prevents a legislature from following on the heels of a judicial decision with legislation that is more protective of religious objectors. ${ }^{93}$ But at the date of this Article's writing, only Connecticut and California have followed a judicial decision requiring recognition of same-sex marriage with legislation giving religious liberty protections ${ }^{94}$ Connecticut expressly allows a religious organization ${ }^{95}$ to refuse to "provide services, accommodations, advantages, facilities, goods, or privileges to an individual if the request for such ... is related to the ... solemnization or celebration" of any marriage - for example, by hosting the wedding reception-when doing so would violate their religious tenets. ${ }^{96}$ Connecticut also shields covered groups from private civil suits for refusing to solemnize or celebrate a marriage. ${ }^{97}$ It further protects them from state action to penalize them or withhold benefits for such refusals. ${ }^{98}$ Lastly, Connecticut expressly allows a religiously affiliated adoption or foster care agency to place children only with heterosexual married couples so long as they receive no government funding for that program. ${ }^{99}$

92. For additional detail, see infra Table A3.

93. Connecticut passed legislation on the heels of a judicial decision requiring same-sex marriage. See Kerrigan v. Comm'r of Pub. Health, 957 A.2d 407 (Conn. 2008); Table A1.

94. See S.B. 899, 145th Gen. Assemb., Reg. Sess. (Conn. 2009) (enacted); S.B. 1140 (Cal. 2012) (amended as Section 400 of the Family Code); see also Kreis \&Wilson, supra note 21.

95. See Conn. Gen. Stat. Ann. § 46b-35a (West Supp. 2013) (covering "a religious organization, association or society, or any nonprofit institution or organization operated, supervised or controlled by or in conjunction with a religious organization, association or society").

96. $I d$.

97. See id. ("Any refusal . . . shall not create any civil claim or cause of action ....").

98. See $i d$. ("Any refusal . . shall not . . result in any state action . . ..").

99. See Conn. Gen. Stat. Ann. § 46b-35b (West Supp. 2013) ("Nothing ... shall be deemed or construed to affect the manner in which a religious organization may provide adoption, foster care or social services if such religious organization does not receive state or federal funds for that specific program or purpose."). For a discussion of an exodus from the marketplace when an exemption for religiously affiliated social services was not forthcoming see Robin Fretwell Wilson, The Calculus of Accommodation: Contraception, Abortion, Same-sex Marriage, and Other Clashes Between Religion, and the State, 53 B.C. L. REv. 1417 (2012) (chronicling the exodus of Catholic Charities after 103 years). 
California enacted stand-alone legislation after Proposition 8, ${ }^{100}$ giving clergy unneeded protection from a duty to solemnize any marriage, if and when same-sex marriage became legal ${ }^{101}$ - a protection that was more symbolic than substantive since the right to refuse is almost certainly secured to them by the First Amendment. ${ }^{102}$ California's stand-alone law also assured religious denominations that they could not lose their tax exemption if they refuse to solemnize any marriage. Because the stand-alone bill protects the tax-exempt status of religious denominations only when refusing to "solemnize" a marriage, a decision surely secured to religious denominations already, ${ }^{103}$ it is highly doubtful whether the stand-alone bill adds anything to constitutional guarantees.

It should surprise no one that the Enacting Jurisdictions provide more meaningful shelter to religious objectors than California's standalone legislation-and certainly than judicial decisions alone. Bargaining power is at its zenith when one party can provide something the other wants. ${ }^{104}$ In the Enacting Jurisdictions, same-sex marriage opponents demanded religious liberty concessions in exchange for support of same-sex marriage. ${ }^{105}$

100. S.B. 1140 (Cal. 2012) (amended as Section 400 of the Family Code).

101. See Cal. Fam. Code $\S 400$ (West Supp. 2013) ("Although marriage is a personal relation arising out of a civil, and not a religious, contract, a marriage may be solemnized by any of the following who is 18 years of age or older: (a) A priest, minister, rabbi, or authorized person of any religious denomination. A person authorized by this subdivision shall not be required to solemnize a marriage that is contrary to the tenets of his or her faith. Any refusal to solemnize a marriage under this subdivision, either by an individual or by a religious denomination, shall not affect the tax-exempt status of any entity.").

102. Marc Stern, Same-Sex Marriage and the Churches, in EMERGing Conflicts, supra note 30; see also Corvino, supra note 26.

103. Hosanna-Tabor Evangelical Lutheran Church \& School v. EEOC, 132 S. Ct. 694, 706-07 (holding that the ministerial exception, grounded in the First Amendment's Religion Clauses, applies to an employee who works in a church-affiliated entity (e.g., in a church school), based on an overall assessment of the role of the employee, which in turn derives partially from the church's own understanding of that role, barring recovery against the entity under the Americans with Disabilities Act).

104. See Sarah Eekhoff Zylstra, Evangelicals' Favorite Same-Sex Marriage Law? Christianity TODAY (Jan. 17, 2014), http://www.christianity today.com/ct/2014/january-web-only/evangelicals-favorite-same-sexmarriage-law-oklahoma-utah.html (As Professor Laycock explains, "Somebody has to credibly say, 'Give us a real religious liberty provision and we'll withdraw our opposition.'").

105. See supra Introduction and accompanying note 24 (interviewing Rick Watrous); see also infra note 116 (interviewing Kach); Schuermann, supra note 21. Clearly, some legislators vote for same-sex marriage because they view it as the right thing to do. For example, 
And same-sex marriage advocates gained from the exchange, too. Consider the legislative experience enacting same-sex marriage in Maryland, charted in Figure 3.

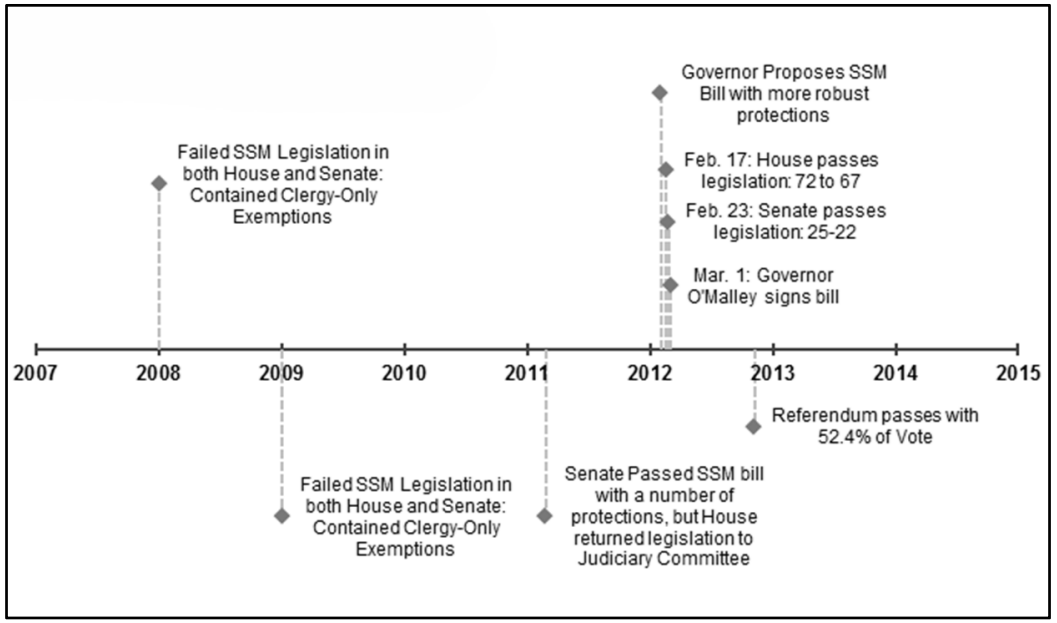

Figure 3: Maryland Same-Sex Marriage Legislation

In 2008, ${ }^{106}$ and again in $2009,{ }^{107}$ bills with illusory, clergy-only exemptions failed. ${ }^{108}$ In 2011, the Maryland House of Delegates again

Representative Heidi Schuermann of the Vermont House of Representatives explained: "I wanted to ensure that equality was there, but at the same time, I wanted to make sure that the language in the public accommodations act allowed [religious organizations] to keep doing the things they've always done." Id.

106. H.B. 351, 425th Leg., 2008 Reg. Sess., (Md. 2008); S.B. 290, 425th Leg., 2008 Reg. Sess. (Md. 2008).

107. H.B. 1055, 426th Leg., 2008 Reg. Sess., (Md. 2009); S.B. 565, 426th Leg., 2009 Reg. Sess., (Md. 2009).

108. Compare H.B. 351, 425th Leg., 2008 Reg. Sess., (Md. 2008) ("That this Act may not be construed to require an official of a religious institution or body authorized to solemnize marriages to solemnize any marriage in violation of the right to free exercise of religion guaranteed by the First Amendment to the United States Constitution and by the Maryland Constitution and Maryland Declaration of Rights."); and S.B. 290, 425th Leg., 2008 Reg. Sess., (Md. 2008) ("That an official of a religious institution or body authorized to solemnize marriages may not be required to solemnize any marriage in violation of the right to free exercise of religion guaranteed by the First Amendment of the United State Constitution and by the Maryland Constitution and Maryland Declaration of Rights.") with H.B. 1055, 2008 Reg. Sess., 426th Leg. (Md. 2009) ("That an official of a religious institution or body authorized to solemnize marriages may not be required to solemnize any marriage in violation of the right to free exercise of religion guaranteed by the First Amendment of the United State Constitution and by the 
introduced a clergy-only bill and sent it across to the Senate, which enlarged the protections and sent it back. ${ }^{109}$ Those new protections ultimately proved insufficient to satisfy hold-out legislators, so the bill died. ${ }^{110}$

In 2012, Governor Martin O'Malley added more protections to the failed bill, this time shielding religious adoption agencies" ${ }^{111}$ in "a conscious attempt" to "pick up additional support in the House."112 The Maryland House narrowly passed the Governor's bill, with a seventy-two to sixty-seven vote, and it cleared the Senate by an

Maryland Constitution and Maryland Declaration of Rights."); S.B. 565, 2009 Reg. Sess., 426th Leg. (Md. 2009) ("That an official of a religious institution or body authorized to solemnize marriages may not be required to solemnize any marriage in violation of the right to free exercise of religion guaranteed by the First Amendment of the United State Constitution and by the Maryland Constitution and Maryland Declaration of Rights.")

Bills with such "hollow" protections have failed everywhere they have been tried. See Kreis \& Wilson, supra note 21.

109. Compare the First Reading version of H.B. 175 and the First Reading version of S.B. 116, 2011 Reg. Sess., 428th Leg. (Md. 2011), http://mgaleg.maryland.gov/2011rs/bills/sb/sb0116f.pdf (restating constitutional protections for the clergy only) with the second iteration of the bill at third reading: S.B. 116, 2011 Reg. Sess., 428th Leg. (Md. 2011) (providing protections for religious organizations and religiously affiliated nonprofits from any requirement to facilitate marriages through accommodations, religious programs, counseling, educational courses, summer camps, and retreats). Senate Bill 116 was amended to immunize these groups from civil claims and government penalties, available at http://mgaleg.maryland.gov/2011rs/bills/sb/sb0116t.pdf.

110. Kreis \& Wilson, supra note 21, at n.90 (quoting Maryland Delegate Pam Biedle, as saying that "[t]he Speaker took a whip count and we knew we were a couple votes short"); see also Luke Broadwater, Md. Bishops Call On Catholics to Oppose Same-Sex Marriage, BALt. Sun (Nov. 9, 2011), http://articles.baltimoresun.com/2011-11-09/news/bs-md-catholic-call20111109_1_religious-liberty-roman-catholic-bishops-religious-freedom (discussing a letter from Maryland's Roman Catholic bishops criticizing the pending same-sex marriage bill for failure to include more expansive religious liberty protections).

111. H.B. 438, S.B. 241, 2012 Leg., 430th Sess. (Md. 2012). The bill introduced on February 1, 2012, broadened the 2011 protections to encompass "promotion of marriage through any social or religious programs or services, in violation of the entity's religious beliefs, unless State or federal funds are received for that specific program or service." Id.

112. John Wagner \& Aaron C. Davis, Governor Unveils Details of his Legislative Agenda, WAsh. Post, Jan. 24, 2012), at B5 ("Religiousexemption language included in O'Malley's same-sex marriage bill is intended to pick up additional support in the House of Delegates, where a bill fell unexpectedly short last year after clearing the Senate."). 
equally slim margin, twenty-five to twenty-two. ${ }^{113}$ The law survived a referendum challenge, with $52.4 \%$ of Marylanders approving it. ${ }^{114}$

Additional protections made all of the difference to the 2012 bill's success. Maryland House of Delegates Speaker Michael Busch said that:

We didn't want to inhibit any religious organization from practicing their beliefs. One of the issues was the adoption issue. We wanted to make sure we didn't impede on the Catholic Church for adoption services. We had a clearer initiative in 2012 and I know for a fact that for two or three delegates [including religious liberty protections] was an important component in their decision to vote for it. ${ }^{15}$

Speaker Busch was not alone in believing that religious liberty protections were critical to the bill's passage. A last-minute vote in support of same-sex marriage came from Republican Wade Kach, who explained that "[w]ithout the religious liberty provisions, I would not have voted for the bill."116 Others in the legislature thought that Delegate Kach would never vote for the bill. ${ }^{117}$ Delegate John Olszewski, a "devoted Methodist [who] was worried about churches that did not want to perform same-sex marriages,"118 delivered an equally crucial vote. He said that his support solidified between 2011 and 2012 because of "the attention to the religious institution

113. See House Bill 438; Senate Bill 241, General Assembly of MARYLAND (2012), http://mgaleg.maryland.gov/webmga/frmMain.aspx $?$ tab $=$ subject $3 \& y s=2012$ rs $/$ billfile $/$ hb0438.htm .

114. See 2012 Presidential General Election Results, MARYLAND.Gov (Nov. 28, 2012, 8:56 AM), http://elections.state.md.us/elections/2012/ results/general/gen_detail_qresults_2012_4_0006S-.html.

115. Telephone Interview by Anthony Kreis with Michael Busch, Speaker of the Md. House of Delegates (July 3, 2012).

116. Telephone Interview by Anthony Kreis with Wade Kach, Member of Md. House of Delegates (Nov. 30, 2012).

117. Telephone Interview by Anthony Kreis with Luke Clippinger, Member of Md. House of Delegates (Nov. 19, 2012) (describing Wade Kach as a vote same-sex marriage advocates "never thought we would get").

118. See Annie Linskey, Searching Souls on Gay Marriage; In the Face of Formidable Pressure, Six Delegates Cast the Deciding Votes, Balt. Sun, Feb. 19, 2012, at 1A. (noting that Del. Olszewski's vote was needed to push "the vote count past the 71 needed to pass the measure"). 
protections." ${ }^{119}$ Had three votes gone the other way, a bill that passed seventy-two to sixty-seven would have failed sixty-nine to seventy. ${ }^{120}$

Religious liberty provisions may have mattered to the referendum's success as well. The ballot text emphasized religious liberty freedoms. While the extent to which Maryland voters understood and accounted for the religious liberty protections in the Civil Marriage Protection Act is unknown, supporters emphasized them in the run up to the referendum. ${ }^{121}$ Governor O'Malley emphasized that there are "strong religious freedom protections for people of all faiths" in Maryland's same-sex marriage legislation. ${ }^{122}$

In short, proponents succeeded when they expanded and honed religious liberty protections. Of course, New York's watershed law six months before the 2012 session, ${ }^{123}$ the active involvement of Governor O'Malley, ${ }^{124}$ and growing public support for same-sex marriage certainly also factored in. ${ }^{125}$

119. Telephone Interview by Anthony Kreis with John Olszewski, Member of the Md. House of Delegates (June 14, 2012).

120. See House Bill 438; Senate Bill 241, General Assembly of Maryland (2012), http://mgaleg.maryland.gov/webmga/frmMain.aspx?tab=sub ject3\&ys=2012rs/billfile/hb0438.htm. See also Linskey, supra note 118 .

121. See, e.g., Gene Robinson, Liberty and Justice for All in Maryland, ON FAITH (Oct. 10, 2012), http://www.faithstreet.com/onfaith/2012/10/ 10/liberty-and-justice-for-all-in-maryland/10097 (endorsing Maryland's same-sex marriage legislation and stating "Maryland is one of many states that has demonstrated the freedom to marry and the freedom to worship are wholly compatible with one another").

122. Gov. Martin O'Malley for Question 6, Youtube (Nov. 3, 2012, at 0:18), http://www.youtube.com/watch?v=Eo95lDAiBEU; see also Protecting Religious Freedom and All Marylanders: Rev. Donté Hickman, YoutuBE (Oct. 3, 2012, at 0:23), http://www.youtube.com/watch?v=-SYSVSQnTnA (supporting the Maryland same-sex marriage law as "protecting religious freedom and all Marylanders equally under the law").

123. See, e.g., Busch, supra note 115 ("Once [same-sex marriage legislation] passed in New York on a bipartisan basis that helped, too.").

124. Maryland's experience began with key legislators taking the lead on crafting religious liberty protections. Later, Governor O'Malley, like Governor Cuomo, guided the crafting of religious liberty protections and championed the underlying legislation. See Annie Linskey, O'Malley introduces same-sex marriage bill, BALT. Sun (Jan. 23, 2012), http://articles. baltimoresun.com/2012-01-23/news/bs-md-same-sex-bill-20120123_1_

marriage-bill-religious-protections-marriage-debate ("O'Malley last year said he would sign a same-sex marriage bill if it passed the General Assembly, but he did not include such legislation in the administration's package. This year, he has said he will lead the fight for the bill.").

125. See Amanda Terkel, Maryland Marriage Equality Poll Shows Increased Support From African-American Voters, Huffington Post (Aug. 2, 2012, 11:05 AM), http://www.huffingtonpost.com/2012/08/02/ marylandmarriage-equality_n_1732555.html (noting the shifting popular opinions 
Like Maryland, in all Enacting Jurisdictions with the exception of two (Minnesota and Delaware), the successful legislation resulted after unsuccessful attempts to enact same-sex marriage with purely symbolic religious liberty protection limited only to the clergy. ${ }^{126}$ Only after ponying up more robust, if imperfect, religious liberty protections did advocates achieve their goal.

Maryland's experience is typical of the progression of successful legislation thus far. Religious liberty protections expand over the course of legislative consideration. Only in Delaware did religious liberty protections not improve over the course of legislative consideration. ${ }^{127}$ In Judicial Decision States, however, there is no opportunity for give-and-take over religious liberty protectionsabsent a later codifying bill.

Some critics say that bargaining for religious liberty protections has "gotten exactly nowhere"-lumping together tangible protections for religious organizations with the almost nonexistent protections for individuals. ${ }^{128}$ Now, it is abundantly clear that existing religious liberty protections do not go far enough to protect individuals outside religious organizations. Legislators have largely ignored the plight of judges, government employees, and those in the wedding industry who cannot assist with a same-sex marriage because of a "relationship with Jesus Christ"129 — or for any other sincerely held religious reason. ${ }^{130}$ Individuals "find little asylum outside the walls of their

towards same-sex marriage and that "a growing majority of state voters say[ they would . . . uphold a state law legalizing same-sex marriage. . . [in addition to rising] support among African-Americans"); see also Nate Silver, How Opinion on Same-Sex Marriage is Changing, and What it Means, N.Y. Times (Mar. 26, 2013, 10:10 AM), http://fivethirtyeight. blogs.nytimes.com/2013/03/26/how-opinion-on-same-sex-marriage-ischanging-and-what-it-means/ (discussing the trend of public opinion on same-sex marriage between 1996 and 2013). See generally infra Part II; Table A5.

126. See Kreis \& Wilson, Embracing Compromise, supra note 21.

127. Id.

128. See Franck, infra, note 37.

129. For example in Washington, a small florist, Arlene Flowers, which had served a same-sex couple for a decade, now faces lawsuits from the state attorney general and the couple for refusing to provide flowers for the couple's wedding because of the owner's "relationship with Jesus Christ." Joel Connelly, AG Sues Florist Who Refused Flowers to Gay Wedding, Seattle Post-Intelligencer (Apr. 9, 2013), http://blog.seattlepi.com/ seattlepolitics/2013/04/09/ag-sues-florist-who-refused-flowers-to-gaywedding/.

130. See Wilson, supra note 89 (discussing firings and other discipline of government clerks who could easily be staffed around without undue burden to employers or coworkers); see also Wilson, supra note 99 (describing 
churches," 131 facing the cruel choice: your livelihood or your conscience. $^{132}$ In effect, without protections, there is the real possibility that members of a number of Christian, Jewish, and other religious groups will effectively be debarred from certain professions relating to weddings. ${ }^{133}$

Nonetheless, circumscribed as they are, religious liberty protections in the Enacting Jurisdictions have netted out to the gain of religious organizations. While critics legitimately fault state lawmakers for not providing all of the religious liberty protections that some urge ${ }^{134}$ it simply is not true that the legislative process has yielded nothing for religious objectors. As the remainder of this Article documents, acting proactively to lock-in religious liberty protections will pay dividends for all.

\section{A (Closing) Political Window for Securing ReLigious LIBERTY}

In the past decade, support for same-sex marriage has escalated, a phenomenon that will only continue. This Part, along with Part III, demonstrates that increasing support, propelled by a constellation of characteristics in the Enacting Jurisdictions, produced a favorable environment for enacting same-sex marriage legislation.

Over the last five years, there has been a tremendous shift in favor of support for same-sex marriage. Nate Silver, a statistician whose modeling has accurately predicted the results of many same-sex

methods for staffing around religious objectors that are invisible to the public, preserving the dignity interests of same-sex couples).

131. Dreher, supra note 40, at 12,15 .

132. Matthew J. Franck, Same-Sex Marriage and Religious Freedom, Fundamentally At Odds, Witherspoon Institute (June 18th, 2013), http://www.thepublicdiscourse.com/2013/06/10393/ ("No state, on the other hand, has credited or accommodated the religiously grounded objections of other private actors-professionals or small business owners - to being dragooned into offering their services on the wedding day to same-sex couples. There are several well-known cases of bakers, photographers - even a religious nonprofit property owner - facing grave legal jeopardy for their refusal to offer their services or facilities in contradiction of their felt obligations to witness to the truth about marriage as it is taught by their faith.").

133. See Laycock, supra note 87 (chronicling the historical barring of Catholics from certain professions in England and Ireland, and Jews elsewhere). Stated differently, without protections specific to marriage, there will be no Evangelical photographers, Orthodox Jewish florists, and the like.

134. See supra note 88 (proposing model religious liberty protections specific to marriage ceremonies or recognition). 
marriage ballot initiatives, ${ }^{135}$ analyzed results from 2008 exit polls in three states. ${ }^{136}$ From that data, he distilled more than a dozen characteristics that were influential to public support or opposition to same-sex marriage; he extrapolates from those characteristics to predict how other jurisdictions would have viewed same-sex marriage if polled in 2008. ${ }^{137}$ Figure 4 shows Silver's calculations for 2008. ${ }^{138}$

135. See Nate Silver, The Future of Same-Sex Marriage Ballot Measures, ThE N.Y. Times (June 29, 2011, 10:35 AM), http://fivethirtyeight. blogs.nytimes.com/2011/06/29/the-future-of-same-sex-marriage-ballotmeasures/; Professor Erwin Chemerinsky, Keynote Speech at UC Davis Law Review Symposium (Feb. 7, 2014), available at http://mediasite. ucdavis.edu/Mediasite/Play/29ec228147e74da09625f244b3de28081d.

(Professor Chemerinsky named Nate Silver "if not the best, then the most prominent pollster.").

136. Silver, supra note 135 (analyzing "individual-level survey results from exit polls in 2008 in the three states that voted on same-sex marriage ballot initiatives that year (California, Florida, and Arizona). Each of these states are quite demographically diverse, and among them more than 5,000 voters were surveyed in the 2008 exit polls.")

137. Id. (explaining his regression analysis: "[i]n essence, the technique is to predict how likely an individual voter is to support same-sex marriage given their particular demographic profile").

138. A literature suggests that ballot exit polls after elections better predict actual views of voters than telephone or other polls because of what is known as the Bradley Effect. The term comes from an election contest for Governor of California in 1982 between African-American mayor of Los Angeles, Tom Bradley, and white opponent, George Deukmejian, in which polls before the election showed measurably more support for Bradley. "Analysts assume that one reason for the discrepancy between the polls and the election result was that white supporters of Deukmejian were reluctant to appear intolerant to survey researchers and thus falsely reported being 'undecided.'" Patrick Egan, Is There Really a "Bradley Effect" for Same-Sex Marriage Initiatives? (Sept. 22, 2008) available at: http://politics.as.nyu.edu/docs/IO/4819/Egan_Bradley_Effect_in_SSM

Initiatives.pdf. As to polling about same-sex marriage, Egan believes "a careful analysis of polling data and election results indicates that if any such 'Bradley effect' exists with regard to same-sex marriage initiatives, it is small - and in 2006 it was effectively zero." Id.; see also Patrick J. Egan, Findings from a Decade of Polling on Ballot Measures Regarding the Legal Status of Same-Sex Couples (June 15, 2010) available at http://www.haasjr.org/sites/default/files/Marriage\%20 Polling.pdf. 


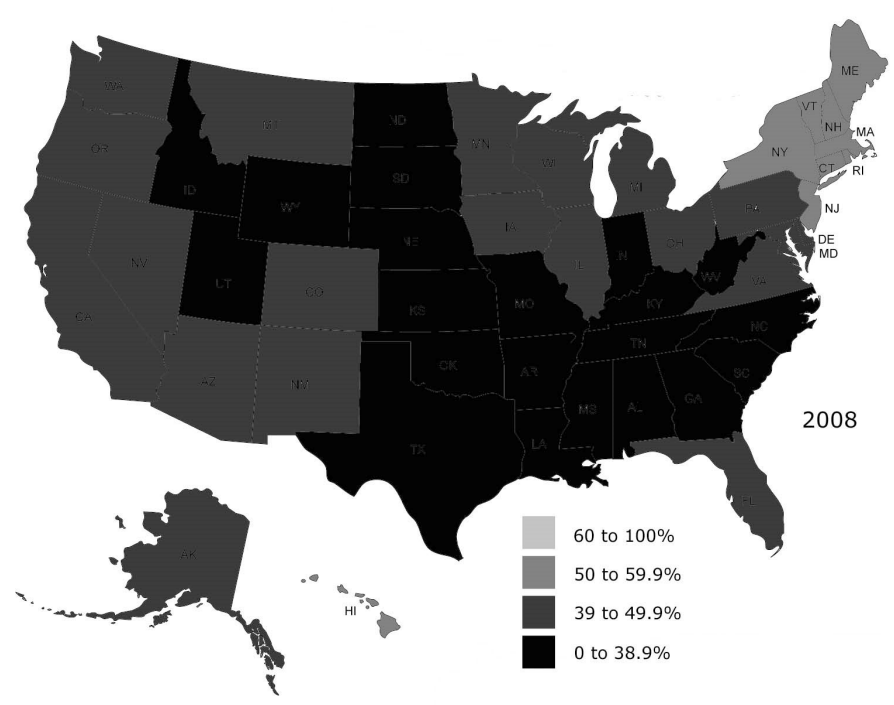

Figure 4: Projected Support for Same-Sex Marriage in Ballot Initiative (2008)

Figure 4 shows support in lighter shades and opposition in darker ones. Support exceeded $50 \%$ in only nine states located in the Northeast - not surprisingly, the incubator of same-sex marriage laws. In the remaining states, support was below $50 \%$ and in twenty-one states, below $39 \%$.

Using the 2008 baseline, Silver projected support, state-by-state, into the present (gauged by his projections for 2012) and out as far as the year 2020. ${ }^{139}$ Figure 5 documents a drastic change in public support between Silver's estimates in 2008 and projections in 2012.

139. Id. 


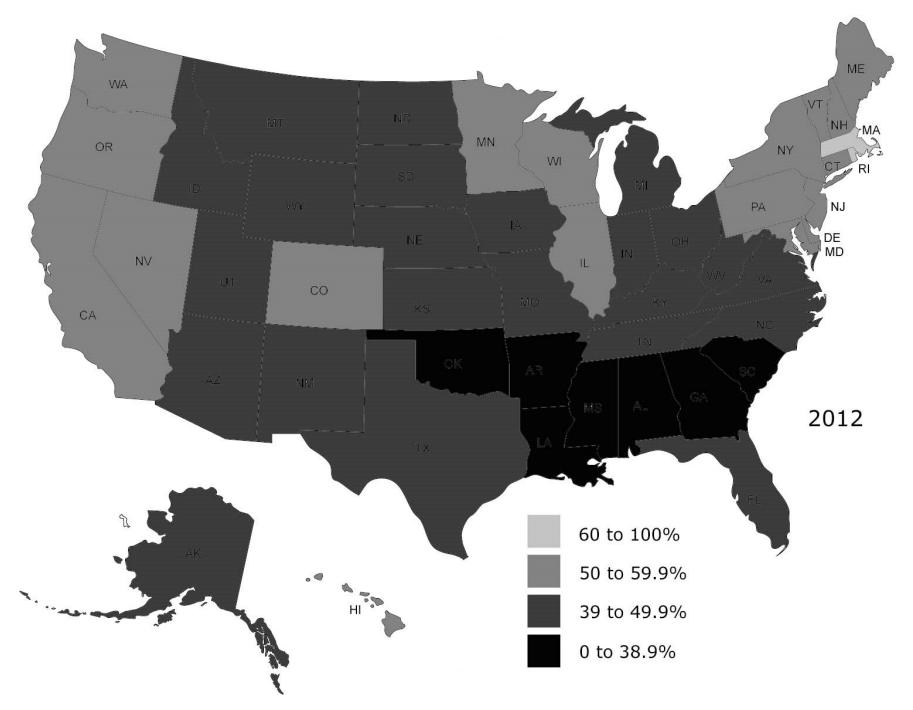

Figure 5: Projected Support for Same-Sex Marriage Ballot Initiative (2012)

By 2012, according to Silver's projections, in twenty-one jurisdictions, a majority of the population supported same-sex marriage (those in the lighter shades). In three jurisdictions, Rhode Island, D.C., and Massachusetts, support ranged as high as 63\%. Only seven states showed support below 39\%, with a total of thirty states having support below $50 \%$.

Of course, Silver's estimates of support for same-sex marriage in 2008 and 2012 may be too generous or even too stingy. Yet, Silver's projections mesh with other reported increases in support for same-sex marriage. According to Gallup, public support has risen consistently since 1996..$^{140}$ In 1996, only twenty-seven percent of Americans believed that marriages between same-sex couples should be legally recognized, providing the same rights as traditional marriages. ${ }^{141}$ By

140. See Jeffrey M. Jones, Same-Sex Marriage Support Solidifies Above 50\% in U.S., GalluP Politics (May 13, 2013), http://www.gallup. com/poll/162398/sex-marriage-support-solidifies-above.aspx (telephone interviewing those 18 and older living in all states and D.C. Gallop weights samples to adjust for "unequal selection probability, nonresponse, and double coverage of landline and cell users in the two sampling frames. They are also weighted to match the national demographics of gender, age, race, Hispanic ethnicity, education, region, population density, and phone status").

141. Id. ("27\% in Gallup's initial measurement on gay marriage, in 1996."). Gallop asked a random sample of 1,535 adults in a May 2-7, 2013, phone interview the following: "Do you think marriages between same-sex couples should or should not be recognized by the law as valid, with the same rights as traditional marriages?" Fifty-three percent responded that 
2004, that slice grew to $42 \%$, before falling to $37 \%$ the next year-a wobble up and down that nonetheless continued in an upward trend

it "should be valid"; $45 \%$ responded that it "should not be valid"; and $3 \%$ had "no opinion." Jeffrey M. Jones, Same-Sex Marriage Support Solidifies Above $50 \%$ in U.S.: Support Has Been $50 \%$ or Above in Three Separate Readings in Last Year, Gallop Politics (May 13, 2013), http://www.gallup.com/poll/162398/sex-marriage-supportsolidifiesabove.aspx.

Mere months later, pollsters at Quinnipaic University asked 1,776 American adults in a phone interview to land lines and cell phones in September 2013, "Would you support or oppose a law in your state that would allow same-sex couples to get married?" and reported that for all adults, $56 \%$ would support it, $36 \%$ would oppose it, and $8 \%$ did not know. Views of registered voters tracked these findings closely, splitting $57 \%$, $36 \%$, and 6\%, respectively. U.S. Catholics Back Pope on Changing Church Focus, Quinnipiac University National Poll Finds; Catholics Support Gay Marriage, Women Priests 2-1, Quinnipiac University (October 4, 2013), available at http://www.quinnipiac.edu/institutes-and-centers/pollinginstitute/national/release-detail?ReleaseID $=1961$. It should surprise no one that results may differ since responses are sensitive to how a particular question is framed and the questions that precede it. For a survey finding significantly less support, see Pew Research Center, infra note 157 (discussing longitudinal study of Americans by Rice University). The well-known Bradley Effect may influence stated support. See Egan, supra note 138 .

Some also point out that Gallup's question followed a question that asked whether "gay or lesbian relations between consenting adults should or should not be legal" and suggest that the order of questions may boost stated support as a result of "priming." Mark Regnerus, What Polls Really Say About Gay Marriage, Chicago Sun-Times (Aug. 20, 2013), http://www.suntimes.com/news/otherviews/22053066-452/what-pollsreally-say-about-gay-marriage.html (citing News That Matters, by political psychologists Donald Kinder and Shanto Iyengar that "document[s] how priming shapes respondents' answers to subsequent questions, particularly where sentiments about a previous question spill over").

In its briefs about same-sex attitudes, Gallup presents "Trends for Comparison" to illustrate responses when the same-sex marriage question followed a sexual relations question and when it did not. Jeff Jones \& Lydia Saad, Gallop News Service: Gallup Poll Social Series: Values and Beliefs Gallop Politics (May 2-7, 2013) http://www.gallup.com/file/poll/ 162404/Gay_marriage_130513.pdf. There, a quick review of those answers shows skewing, but in different directions at different times. Thus, in an August 22-25, 2005, poll in which the same-sex marriage question was preceded by the sexual relations question, $37 \%$ said same-sex marriage "should be valid." $I d$. at 2 . A contemporaneous survey conducted on April 29-May 1, 2005, asking only the marriage question found that slightly more, $39 \%$, said it should be valid. By contrast, in 2004, 42\% responded that same-sex marriage "should be valid" in a survey that first asked about the legality of sexual relations. In a contemporaneous survey with only the marriage question, $33 \%$ said it should be valid. $I d$. at 2 (reporting results of polls in May 2-4, 2004, and March 5-7, 2004, respectively). 
for several years. ${ }^{142}$ By the end of 2010, a majority of those polled believed that "marriages between same-sex couples should ... be recognize[d] by the law." And that number reached $53 \%$ in 2011. Gallop reported in May 2013 that support across the United States remained at or above $50 \%$ in "three separate readings in the last year." 143

It is worth pausing to note the explanatory power of these statistics. Until 2012, same-sex marriage opponents had "won" twenty-nine consecutive constitutional amendments fights - putting aside Arizona's 2006 failed constitutional amendment to ban same-sex marriage and civil unions both. ${ }^{144}$ That streak ended abruptly in 2012 when opponents lost the referenda over Washington ${ }^{145}$ and Maryland's same-sex marriage laws, ${ }^{146}$ failed to secure a constitutional amendment in Minnesota, ${ }^{147}$ and Maine voters enacted same-sex marriage at the ballot box ${ }^{148}$ - all of which occurred after the tide of national public opinion had shifted in favor of same-sex marriage.

Silver projects that this uptick in support will only continue. As Figure 6 shows, by 2016, more than half of all voters in a clear majority of jurisdictions, thirty-two, are projected to support samesex marriage. Voters in only two states, Alabama and Mississippi, show support below 39\%, while in nineteen states support remains below $50 \%$. Silver projects that in thirteen states, more than $60 \%$ of voters will support same-sex marriage.

142. Jones, supra note 140 (presenting results of Gallup polling across time). Support grew to $46 \%$ by 2007 but fell again to $40 \%$ in years 2008 and 2009.

143. Id.

144. See Kreis \& Wilson, supra note 21.

145. Voters sustained Washington's law by a popular vote of $53 \%$ to $47 \%$ in the November 2012 referendum. See Noah Michelson, Minnesota Amendment 1 Same-Sex Marriage Ballot Measure Fails, Huffington PosT (Nov. 7, 2012, 7:41 AM), http://www.huffingtonpost.com/ 2012/11/07/minnesota-amendment-1-results-2012_n_2050310.html. See generally Table A5 for support in the state at the time of legislation.

146. See supra notes 121-124 and accompanying text (describing Maryland's 2012 referenda supporting same-sex marriage). See generally Table A5 for support in the state at the time of legislation.

147. See Michelson, supra note 145 ("Minnesota voters voted against an amendment on Nov. 6 that would have defined marriage as being between a man and woman in the state's constitution ....").

148. 2012 General Election Results for Maine, BANGOR DAILY NEWS (last updated Nov. 14, 2012), http://web.archive.org/web/ 20130118025105/http://maineelections.bangordailynews.com/ $\quad(47.4 \%$ responded "no") (accessed by searching for the original URL in the Internet Archive index). 


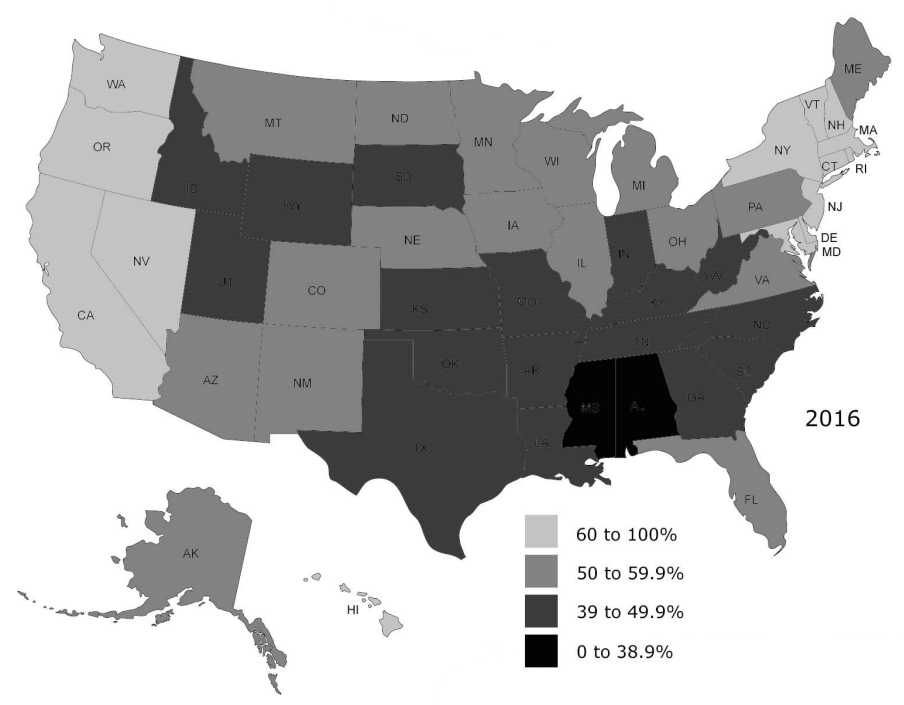

Figure 6: Projected Support for Same-Sex Marriage in Ballot Initiative (2016)

By 2020, represented in Figure 7, Silver projects overwhelming support for same-sex marriage. At that point, only in Mississippi will support for same-sex marriage remain below 39\%. In all states but six (South Carolina, Arkansas, Georgia, Louisiana, Alabama, and Mississippi), a majority of voters are projected to support same-sex marriage. In four of the latter (South Carolina, Arkansas, Georgia, and Louisiana), support for same-sex marriage is projected to be within two percentage points of a majority. In twenty-four jurisdictions, over $60 \%$ of voters are projected to support same-sex marriage. 


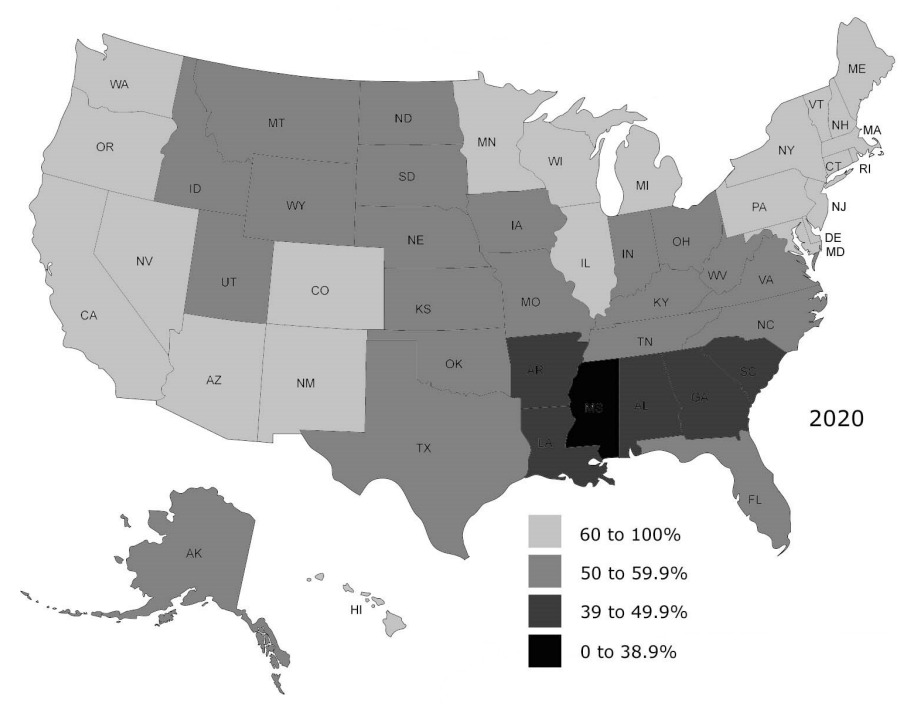

Figure 7: Projected Support for Same-Sex Marriage in Ballot Initiative (2020)

In Silver's view, "the steadiness" of this trend-line:

makes same-sex marriage virtually unique among all major public policy issues, and which might give its supporters more confidence that the numbers will continue to break their way. ${ }^{149}$

Given all this data, it would be surprising if advocates did not think same-sex marriage was inevitable. In fact, $85 \%$ hold the belief that "legal recognition of same-sex marriage is 'inevitable." "150

Fifty-nine percent of opponents also believe it is inevitable. ${ }^{151}$ Of all people polled on the question, $72 \%$ in 2013 said "legal recognition of same-sex marriage is "inevitable," " up from $59 \%$ in $2004 .{ }^{152}$ In every demographic group polled, except those aged 18-29, the fraction who believed same-sex marriage to be inevitable increased from March of

149. Silver, supra note 125 .

150. Pew Research Center for the People \& the Press, In Gay Marriage Debate, Both Supporters and Opponents See Legal Recognition as "Inevitable" 1 (2013).

151. Id. Interestingly, the belief of inevitability extends to those most opposed to same-sex marriage. Seventy percent of white evangelicals, only $22 \%$ of whom favor same-sex marriage, believe same-sex marriage recognition is inevitable. $I d$. at 3 . While $31 \%$ of Republicans favor samesex marriage, $73 \%$ believe recognition is inevitable. Id. Finally, $39 \%$ and $45 \%$, respectively, of blacks and those 50-64 favor same-sex marriage, while $69 \%$ and $74 \%$, respectively, believe it to be inevitable. Id.

152. Id. at 1 . 
2004 to May of 2013. ${ }^{153}$ Even the most "tireless opponent" of same-sex marriage, Maggie Gallagher, believes same-sex marriage is a "foregone conclusion." $" 154$

Of course, people could be misgauging opposition, causing a rush to the judgment that "the game is over." But at least Gallup polling suggests otherwise. When people misjudge public support, they tend to see "most Americans [as] com[ing] down on the side of not legalizing it." ${ }^{155}$ In other words, most people who misjudge support for same-sex marriage estimate on the low side, not the high side, but they nonetheless see same-sex marriage as inevitable.

The demographic profile of those opposed to same-sex marriage can only make same-sex marriage more inevitable. ${ }^{156}$ Social scientists

153. Id. at 7 .

154. Dreher, supra note 40, at 12.

155. See Jones, supra note 140 (emphasis in original).

156. It is always difficult to predict the future. One thorny question is whether, notwithstanding the broader trend of increasing support for same-sex marriage, individual attitudes will harden against same-sex marriage as those individuals age (e.g., if they become more conservative with age) or for other reasons. Far more probative of this possibility than national polls over time are longitudinal surveys of the same respondents. Researchers at Rice University have tracked responses to the statement, "the only legal marriage should be between one man and one woman." Michael O. Emerson \& Laura J. Essenburg, What Is Marriage? Americans Dividing, Kinder Institute for Urban Research (June 24, 2013) available at http://kinder.rice.edu/uploadedFiles/Kinder_Institute_for Urban_Research/Publications/White_Papers/Marriage\%20Definition\%20 White\%20Paper.pdf. Interviewing the same 1,294 Americans in 2006 and again in 2012, researchers found that "no significant overall change between 2006 and 2012," with a slight majority, $57 \%$ and $53 \%$, opposed to same-sex marriage in 2006 and 2012, respectively. Id. In those years, $31 \%$ and $33 \%$, respectively, supported same-sex marriage. $I d$. at 5 , Fig. 1 . This rough constancy masked changes in individual attitudes.

Sixteen percent of those who originally opposed same-sex marriage (i.e., agreed with the statement) changed their view to supporting same-sex marriage (i.e., disagreed) over the intervening years. Id. at 5-6, Fig. 2. Twenty-eight percent of people who supported same-sex marriage in 2006 (i.e., "disagreed" with the statement) reported being against same-sex marriage by 2012 (i.e., they "agreed"). Id. at 6 . Nearly two-thirds of those in the undecided category, "who in 2006 neither disagreed nor agreed with the statement ( $13 \%$ of the sample), by 2012 . . had taken a different position: $42 \%$ disagreeing, and $23 \%$ agreeing." Id. at 6 . In all, among those who people changed a fixed view, a greater fraction went from supporting same-sex marriage to opposing it (i.e., from "disagreeing to agreeing"); for those on the fence in 2006, a greater fraction embraced same-sex marriage by 2012 .

The division in opinion between 2006 and 2012 grew "along educational, religious, and age lines," suggesting a "growing cultural divide across the nation." Id. at 1 . 
and polling groups alike have all documented a generational divide over same-sex marriage. ${ }^{157}$ In general, younger people are more supportive of same-sex marriage, and support reliably drops off with age.

Pew, for example, found that in 2013, 66\% of "Millenials," those born after 1981, who in 2013 were less than 33 years old, supported same-sex marriage. ${ }^{158}$ Fifty-two percent of "Generation X," those born between 1965 and 1980, who in 2013 were between 33 and 49 years old, support same-sex marriage. ${ }^{159}$ Only $41 \%$ of "Baby Boomers," those born between 1946 and 1964, who in 2013 were between 49 and 67 years old, support same-sex marriage. ${ }^{160}$ Only slightly more than a third, 35\% of the "Silent Generation," those born between 1928 and 1945 who in 2013 were 68 to 85 years old, favor same-sex marriage. ${ }^{161}$ In every age bracket, stated support in 2013 represented the record high since polling began in 2001. The gap between generations is a persistent one. For example, in no year since 2013 was the gap between the Millennials and Generation X less than 4\%. This support

Importantly, the law of the jurisdiction in which the respondent lived seemed not to have influenced the findings. Researchers "examined the opinions of Americans depending on whether they live in a state that defines marriage as one man and one woman (29 states [at the time of the study]) or not (21 states [at the time of the study])," expecting to see a red-blue divide. $I d$. at 7 .

Instead they found that "[r]egardless of what type of state people live in, in $2012,54 \%$ agreed with the marriage statement, about a third disagreed, and the remainder was uncertain." They concluded that "how marriage is legally defined across the states has little to do with actual public opinion, and more to do with higher-level political debates and special interest groups." Id.

Even though individuals who once supported same-sex marriage may harden against it, it seems unlikely that this hardening will reverse the broader trend of greater support. Younger people are not going to uniformly change their opinions to oppose same-sex marriage, even if some younger adults do as they age. See infra notes 156-65 and accompanying text (discussing persistent divide according to age on stated support for same-sex marriage).

157. See Pew Research Center, Changing Attitudes on Gay Marriage, PEW Research: Religion \& Public Life Project (June 2013), http://features.pewforum.org/same-sex-marriage-attitudes/slide2.php ("Younger generations express higher levels of support for same-sex marriage.").

158. Id.

159. Id.

160. Id.

161. Id. 
among the younger generations extends even to young evangelicals, ${ }^{162}$ a group in which support for same-sex marriage is typically lower than average. ${ }^{163}$

Opponents of same-sex marriage could afford to ignore the phenomenon of a generational divide if it was localized to a fraction of states. However, the phenomenon is universal across all fifty states, as Figure 8 illustrates. Taking actual polling numbers from 1994 through 2008, which they then weighted, Professors Jeffrey Lax and Justin Phillips broke down support for same-sex marriage by state and age group for 2009. ${ }^{164}$ In no state did younger voters show less support than older ones.

162. Neil King Jr., Evangelical Leader Preaches a Pullback From Politics, Culture Wars, Wall St. J., Oct. 22 2013, at A1. The Wall Street Journal reported in 2013 that $51 \%$ of young evangelicals, those aged 18 to 34 years, either "strongly favored" or "favored" same-sex marriage. By contrast, only $15 \%$ of evangelicals who were 65 years and older either "strongly favored" or "favored" same-sex marriage. Id. The reporting about these findings has been controversial. See Napp Nazworth, Russell Moore Clarifies Misleading WSJ Article, Praises Predecessor's 'Prophetic Voice,' Christian Post Reporter (Oct. 24, 2013), http://www.christianpost.com/news/russell-moore-clarifiesmisleading-wsj-article-praises-predecessors-prophetic-voice-107387/.

163. See Pew Research Center, supra note 157 ("Support among white evangelical and black Protestants remains lower than other groups.").

164. Jeffrey R. Lax \& Justin H. Phillips, Gay Rights in the States: Public Opinion and Policy Responsiveness, 103 Am. PoL. SCI. REV. 367, Fig.8 (online appendix only) (2009), available at http://www.columbia.edu/ jr 12124/Lax_Phillips_Gay_Policy_Responsiveness_2009.pdf. 


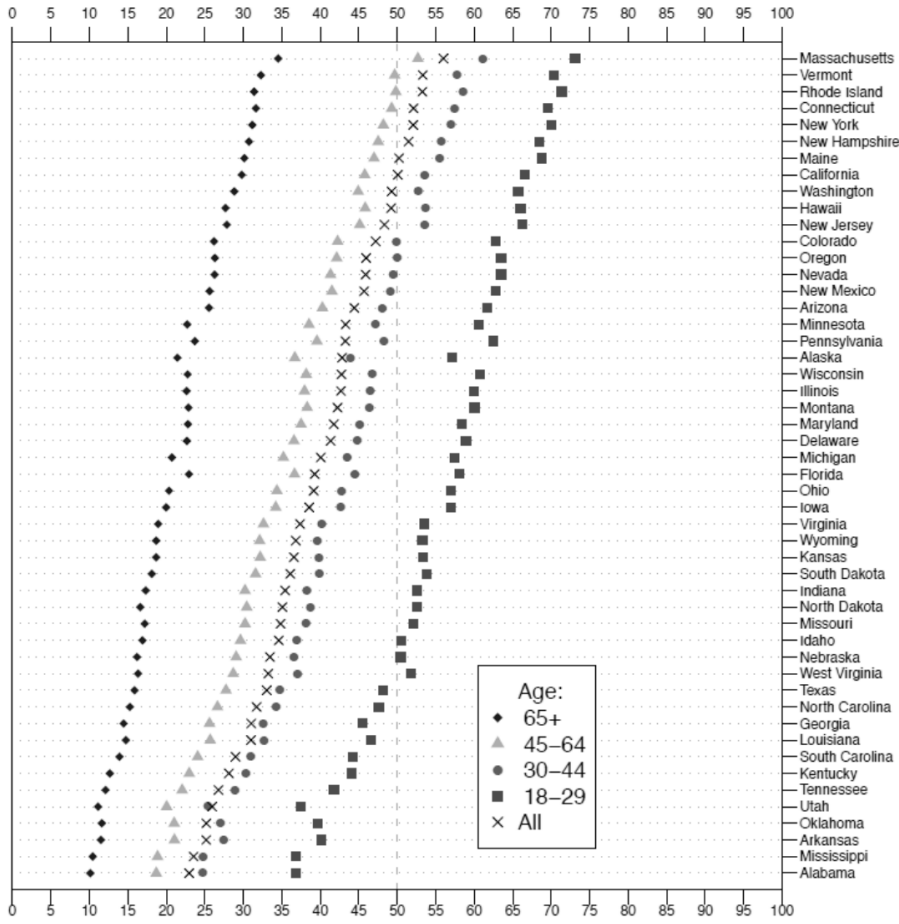

Figure 8: Explicit Support for Same-Sex Marriage by State and Age. Data from 1994 to 2008; estimates weighted for 2008. ${ }^{165}$

And matters are only going to get worse for opponents. To show the effects of the strongest objectors passing from the scene, Figure 9 replicates Lax and Phillips' data. ${ }^{166}$ In it, each age group is weighted by their relative fraction in a given state's population, using 2010 Census data where possible. ${ }^{167}$ The calculated averages in Figure 9 closely track Lax and Phillips' figure.

165. Id. Reprinted with permission.

166. Id. While Figure 9 is an approximation because it begins with data in Lax and Phillips' published figure as opposed to their data set, it illustrates the effect of the oldest generation passing away.

167. Lax and Phillips broke out state populations into four groups: 18-29, 30-44, 45-64 and 65+. Id. at 384. Figures 9 and 10, and the calculations used to generate them contained in Table A7, use Census data for age groups 45-64, and 65 and older. See generally U.S. Census Bureau, 2010 Census Briefs Age And Sex Composition: 2010 (2011), available at http://www.census.gov/prod/cen2010/briefs/c2010br-03.pdf. Because the Census breaks down the group that is 18-44 years into those who are 18-24 years and 25-44 years, it was not possible to use Census numbers to generate the relative fraction of these groups to the voting age population. Consequently, Figures 9 and 10 and Table A7 


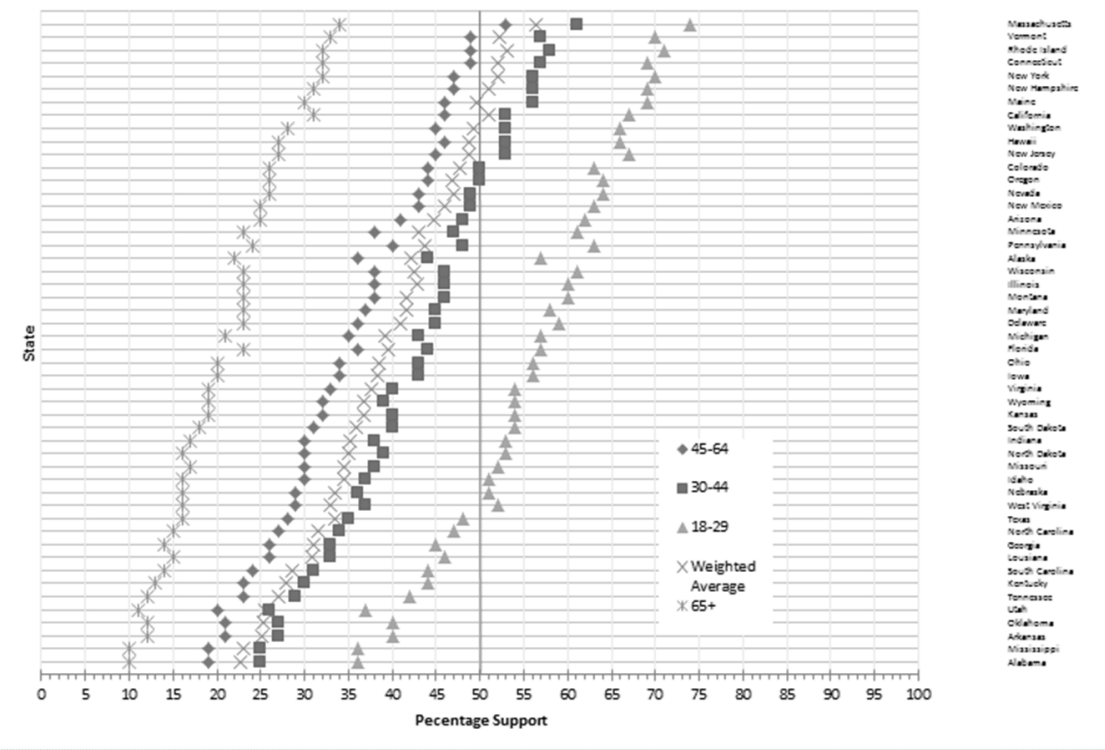

Figure 9: Support for Same-Sex Marriage by State and Age, including individuals 65 years and older

Figure 10 then eliminates the oldest generation, the effect of which is that the weighted average support in every state shifts to the right, showing greater average support. In 2009, without the oldest generation, an additional eight states cross the threshold to a majority of the population supporting same-sex marriage, bringing the total to fifteen states in which a majority would have supported same-sex marriage. An additional six states would be closing in on majority

use Lax and Phillips' fractional breakdown by state for the groups $18-29$ and $30-44$.

See Lax \& Phillips, supra note 164. Thus, in Alabama, the 2010 Census reported that $26.8 \%$ were between 45 and 64 , and $13.8 \%$ were over the age of 65. See U.S. Census Bureau, 2010 Census Briefs Age And Sex Composition: 20107 (2011), available at http://www. census.gov/prod/cen2010/briefs/c2010br-03.pdf; Table A7, 3rd set of columns.

Lax and Phillips reported that $18.5 \%$ of the Alabama population was between 18 and 29 , while $19.2 \%$ were $30-44$. To generate weighted averages, we calculated what percent each group represented to the voting age population. In other words, the denominator did not include those under the age of eighteen.

Table A7 presents the relative weights of each age group used to produce Figures 9 and 10, as well as the state by state population broken down by age group drawn from the 2010 Census and Lax and Phillips' data. See Table A7. 
support, with support above $45 \%$. While Figure 10 can only provide a coarse approximation, ${ }^{168}$ it illustrates that public support will likely balloon with time.

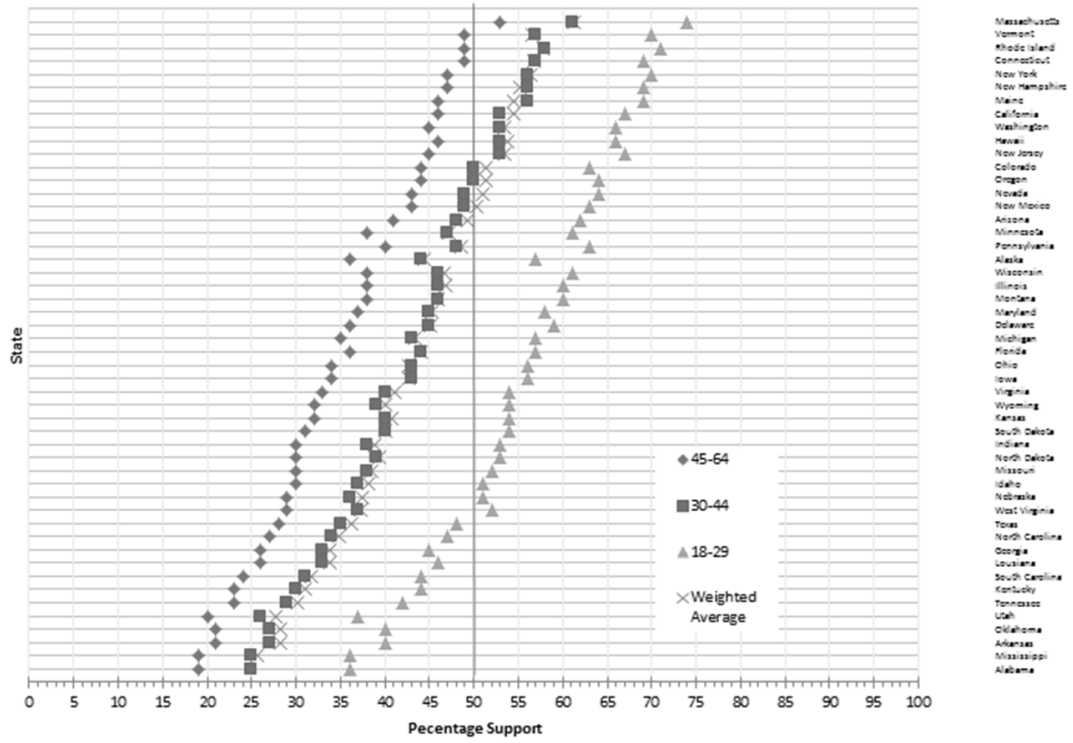

Figure 10: Support for Same-Sex Marriage by State and Age, without individuals 65 years and older

Other factors contribute to increased support, as well:

As a rule of thumb, perhaps about half of the increase in support for same-sex marriage is attributable to generational turnover, while the other half is because of the net change in opinion among Americans who have remained in the electorate. ${ }^{169}$

Changing attitudes toward same-sex marriage and homosexuality among the electorate explains some of the softening of opposition. More Americans have gay family members, or now know that they do, and more have familiarity with lesbians and gays. ${ }^{170}$ Many more

168. See Table A7 for data used to arrive at the weighted average without individuals who are 65 and older. To really capture how quickly the window is closing, one would have to age in new voters who turn eighteen, who presumably, like their counterparts under twenty-nine, will voice strong support for same-sex marriage.

169. See Silver, supra note 125.

170. See generally Pew Research Center for the People \& the Press, supra note 150 . By $2013,87 \%$ of Americans " $\mathrm{kn}[\mathrm{e}] \mathrm{w}$ someone who is gay or lesbian" - up from $61 \%$ twenty years before. Id. at 1 . Twenty-three 
now do not share the view that same-sex marriage "will be bad for marriage, bad for children, and very bad indeed for those people of faith who want to maintain their faith's teaching on marriage, in their religious institutions and in their work." ${ }^{171}$

In the face of these trends, some opponents urge that religious liberty protections provided cover for cowardly legislators who otherwise would have not voted to allow marriage equality. Specifically, they say exemptions "allow[] a legislature to do the wrong thing, which is pass same-sex marriage." ${ }^{172}$ Certainly, the close vote counts shown in Table 1 lend credence to the view that religious liberty protections mattered to the outcome in some states.

percent of people know "a lot" of gay and lesbian people while $44 \%$ know some. Id. Forty-nine percent have "a close family member or" a close friend who "is gay or lesbian." Id. Additionally, $31 \%$ know a samesex couple raising children. $I d$. Pew Research Center explains that "even holding demographic factors constant, those who have many gay acquaintances, or close gay friends and family members, are more likely to favor same-sex marriage than those who do not." Id. at 16.

171. See Franck, supra note 37. A shrinking fraction of people express negative views about same-sex couples raising children. PEW RESEARCH Center for the People \& the Press, supra note 150, at 11. Even a few years has made a difference. Id. When asked if it is a good, bad, or does not matter for "American society" to have same-sex couples raising children, in April 2013, 21\% said it is good, 35\% bad and $41 \%$ said not much difference in. Id. In March 2011, 14\% said good, 35\% bad, and $48 \%$ said it does not make a difference. Id. In February 2007, only $11 \%$ said that it was good, while $50 \%$ said it was bad and $34 \%$ said it did not make much difference. $I d$.

172. Matthew Brown, Why America's Long History of Protecting Religion Is at the Center of Gay Marriage Debate, DESERET NEws NAT'L, Nov. 14, 2013, http://www.deseretnews.com/article/865590501/WhyAmericas-long-history-of-protecting-religion-is-at-the-center-of-the-gaymarriage-debate.html?pg=all (quoting Matt Franck as saying exemptions "'allow[] a legislature to do the wrong thing, which is pass same-sex marriage, which is bad for marriage, bad for kids and bad for religious freedom no matter what concessions you think you are making'"). 
Case Western Reserve Law Review · Volume $64 \cdot$ Issue $3 \cdot 2014$ Marriage of Necessity

TABle 1: Enacting Jurisdictions Vote Counts and Support for Same-Sex Marriage

\begin{tabular}{|c|c|c|c|c|c|c|c|}
\hline \multirow{2}{*}{$\begin{array}{c}\text { ENACTING } \\
\text { JURISDICTION }\end{array}$} & \multicolumn{2}{|c|}{ Vote Count House } & \multicolumn{3}{|c|}{ Vote Count Senate } & Support at \\
\cline { 2 - 7 } & For & Against & $\begin{array}{c}\text { \% } \\
\text { For }\end{array}$ & For & Against & $\begin{array}{c}\text { \% } \\
\text { For }\end{array}$ & $\begin{array}{c}\text { Time of } \\
\text { Enactment }\end{array}$ \\
\hline Connecticut & 100 & 44 & $69 \%$ & 28 & 7 & $80 \%$ & $52 \%$ \\
\hline Delaware & 23 & 18 & $56 \%$ & 12 & 9 & $57 \%$ & $54 \%$ \\
\hline District of Columbia & 11 & 2 & $85 \%$ & \multicolumn{2}{|c|}{ DC is unicameral) } & $57 \%$ \\
\hline Hawaii & 30 & 19 & $61 \%$ & 19 & 4 & $83 \%$ & $55 \%$ \\
\hline Illinois & 61 & 54 & $53 \%$ & 34 & 21 & $62 \%$ & $50 \%$ \\
\hline Maryland & 72 & 67 & $52 \%$ & 25 & 22 & $53 \%$ & $52 \%$ \\
\hline Minnesota & 75 & 59 & $56 \%$ & 37 & 30 & $55 \%$ & $46 \%$ \\
\hline New Hampshire & 198 & 176 & $53 \%$ & 14 & 10 & $58 \%$ & $55 \%$ \\
\hline New York & 80 & 63 & $56 \%$ & 33 & 29 & $53 \%$ & $55 \%$ \\
\hline Rhode Island & 56 & 15 & $79 \%$ & 26 & 12 & $68 \%$ & $56 \%$ \\
\hline Vermont & 95 & 52 & $65 \%$ & 26 & 4 & $87 \%$ & $54 \%$ \\
\cline { 2 - 6 } Vermont Veto & 100 & 49 & $67 \%$ & 23 & 5 & $82 \%$ & - \\
\hline Washington & 55 & 43 & $56 \%$ & 28 & 21 & $57 \%$ & $53 \%$ \\
\hline
\end{tabular}

As noted above, many commentators and legislators believe that protections did, in fact, matter to the legislation's ultimate success. ${ }^{173}$ At least one legislator, Vermont House Leader Lucy Leriche, candidly says she and others would have supported a law without exemptions if it was feasible, but it was not:

We couldn't have [passed same-sex marriage legislation] without the religious liberty exemptions. If we could have, we would have, honestly. But we would not have been able to get enough votes without them. ${ }^{174}$

A more salient question is whether any enacted law would have passed within a year or two, with or without protections. In every Enacting Jurisdiction (except Minnesota), a majority of the populace supported same-sex marriage at the time of enactment. ${ }^{175}$ Even in the states where the vote counts were closest (Illinois, Maryland, New Hampshire, and New York), a majority, albeit slight, of the state's population supported same-sex marriage. Given growing public

173. See supra notes $23-31$ and accompanying text.

174. Telephone Interview by Anthony Kreis with Lucy Leriche, Vt. House of Representatives Assistant Majority Leader (June 26, 2012). Not every legislator attaches the same weight to the religious liberty protections. A primary sponsor of Vermont's same-sex marriage bill, Senator Claire Ayer, minimized them as "putting a little oil in the water." Telephone Interview by Anthony Kreis with Claire Ayer, Vt. State Senator (May 28, 2009); see Kreis \& Wilson, supra note 21.

175. See infra Tables A4 and A5. 
support across the country, it is likely that same-sex marriage would have passed eventually in some form-but it would have required delaying marriage for couples clamoring to marry. Making enactment of same-sex marriage in those jurisdictions all the more inevitable, the same-sex marriage movement has followed a tried and true pattern, as Part III shows.

\section{A Cluster of Political Factors Supported MarRiage Equality}

Social scientists identify a short list of demographic factors that influence support for same-sex marriage. While other factors matter to public support, ${ }^{176}$ experts note that:

1) Democrats tend to support same-sex marriage in huge numbers, ${ }^{177}$

2) Religious affiliation, or lack of it, matters to same-sex marriage support ${ }^{178}$ as does weekly or rare church attendance, ${ }^{179}$

3) Those with greater formal education tend to favor same-sex marriage. ${ }^{180}$

Taking a deeper look at the Enacting Jurisdictions, it is no surprise that they share this cluster of characteristics. ${ }^{181}$ As Figure 11 shows,

176. See Silver, supra note 125. Silver posits that a number of other factors also influence support for same-sex marriage ("There are clearly a number of other factors that also affect opinion on same-sex marriage, however, most notably age, race, urbanity, and education levels.").

177. See Pew Research Center, supra note 157.

178. See id.

179. Lydia Saad, In U.S., 52\% Back Law to Legalize Gay Marriage in 50 States, Gallup Politics (Jul. 29, 2013), http://www. gallup.com/poll/163730/back-law-legalize-gay-marriage-states.aspx. In a longitudinal study of the same 1,294 Americans in 2006 and 2012, Rice University researchers identified three characteristics as strongly influencing attitudes on same-sex marriage recognition- "most especially education, religion, and age." Emerson \& Essenburg, supra note 156.

180. Id.; see also Silver, supra note 125.

181. Obviously, some characteristics may influence (a) public support for same-sex marriage and (b) any specific political characteristic, like Democratic control of the legislature. For example, urbanity of a state may yield both Democratic control and high support. This Article is intended to give a descriptive account of a handful of state-level characteristics that might have influenced the legislative process. Clearly a more sophisticated analysis would control for multiple variables through regression to tease out, with greater specificity, what factors 
in every Enacting Jurisdiction (except New York ${ }^{182}$ ), Democrats controlled both houses of the legislature. In the sole exception, the New York Senate, a handful of holdout Republican Senators demanded, and received, religious liberty protections that exceeded those meager protections proffered by New York Governor Andrew Cuomo. ${ }^{183}$

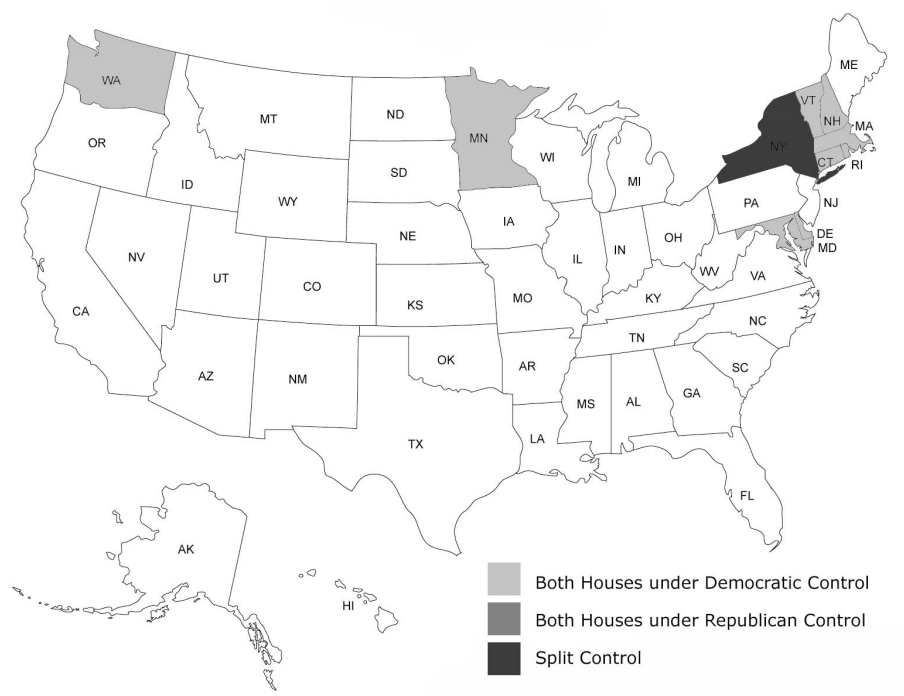

Figure 11: Legislative Control at Time of Successful Same-Sex Marriage Legislation

As illustrated in Figure 12, every Enacting Jurisdiction had a Democratic Governor, with the exception of Connecticut and Vermont. ${ }^{184}$ Connecticut's Republican Governor had no choice but to sign the legislation given the Connecticut Supreme Court's decision in

matter most. With so few states having enacted same-sex marriage, a statistical analysis of this kind may not be feasible. This Article only seeks to take characteristics identified by others as influential and use them to assess the political terrain going forward.

182. See infra Table A4 (showing that New York's Senate was controlled by the Republican Party). See generally Table A4 for underlying data.

183. See Kreis \& Wilson, supra note 21 (showing progression of legislation in New York); see also Christopher W. Dickson, Inseverability, Religious Exemptions, and New York's Same-Sex Marriage Law, 98 CORNELL L. REV. 181, 183 (2012) (reporting that legislators agonized over religious liberty protections).

184. See generally Table A4 for underlying data. 
Kerrigan v. Commissioner of Public Health. ${ }^{185}$ The Vermont Legislature overrode the Republican Governor's veto by a vote of twenty-three to five in the Senate and one hundred to forty-nine in the House. ${ }^{186}$

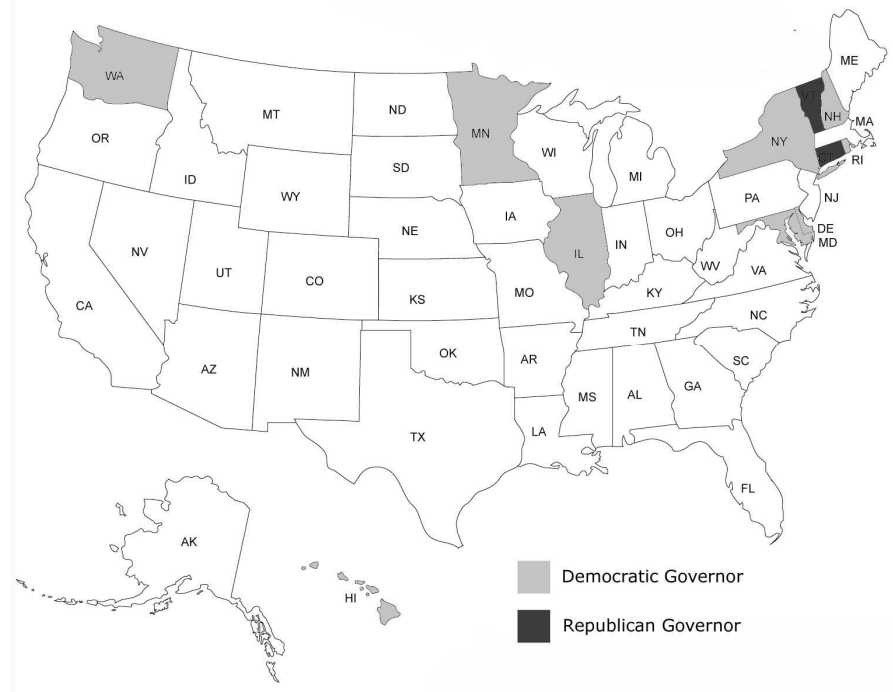

Figure 12: Governor Party at the Time of Same-Sex Marriage Legislation

With scattered exceptions, the Enacting Jurisdictions all had populations that rank among the least religious but most educated. ${ }^{187}$ To measure "religiosity," Gallup conducts telephone interviews with individuals eighteen years and older living in all states and D.C. and asks whether "religion is an important part of their daily life and [whether] they attend religious services every week or almost every week," and based on that response, reports the percentage of the population that is "very religious." 188 To assess the influence of religiosity, Table A4 presents Gallop's measure of "religiosity" by state. Rank-ordering the states from most religious to least allows one to then break those states into thirds. Every Enacting Jurisdiction

185. 957 A.2d 407, 412 (Conn. 2008) (striking down a law limiting marriage to heterosexual couples based on the Connecticut Constitution's equal protection clause).

186. See Vt. State Legislature, Current Status of a Specific Bill or Resolution: 2009-2010 Legislative Session (2010), available at http://www.leg.state.vt.us/database/status/summary.cfm?Bill=S.0115\& Session $=2010$.

187. See generally Table A4 for underlying data.

188. Frank Newport, Mississippi Maintains Hold as Most Religious U.S. State, Gallup Politics (Feb. 13, 2013), http://www.gallup.com/poll/ 160415/mississippi-maintains-hold-religious-state.aspx\#1. 
ranks among the lowest third in religiosity in the country-except four (Delaware, Illinois, Maryland, and Minnesota), which occupy the lower portion of the middle third, as Figure 13 shows. ${ }^{189}$

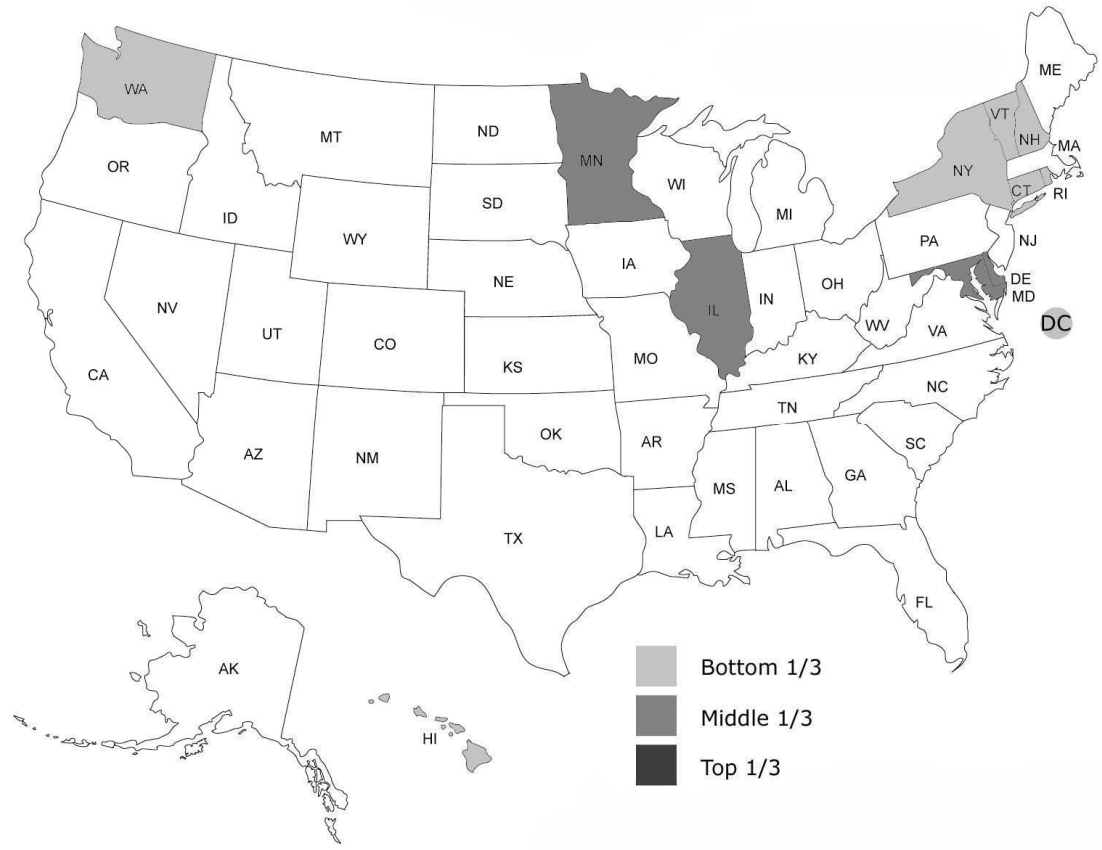

FIGURE 13: Ranking of Enacting Jurisdictions by Religiosity

Figure 14 is based on educational attainment data derived from Census Bureau reports on the percentage of the population with a bachelor's or advanced degree. ${ }^{190}$ Rank ordering states from the highest to the lowest, in thirds, reveals that in the Enacting Jurisdictions, every state falls in the top one-third for educational attainment, except Hawaii. Hawaii appears near the top of the middle rung.

189. One might predict that statutory, if not constitutional, protections for religious freedom might roughly track self-identified religiosity among the states populace. Here it is interesting to note that among the Enacting Jurisdictions, three had enacted state RFRAs, modeled on the federal RFRA. See supra note 76 (listing Connecticut, Illinois and Rhode Island as the three Enacting Jurisdictions with state RFRAs). So, despite, the fact that Enacting Jurisdictions are generally ranked low for religiosity, three of them have enacted protections for religion.

190. See generally Table A4 for underlying data; Educational Attainment, US Census Bureau (2011), available at http://www.census.gov/hhes/ socdemo/education/. 


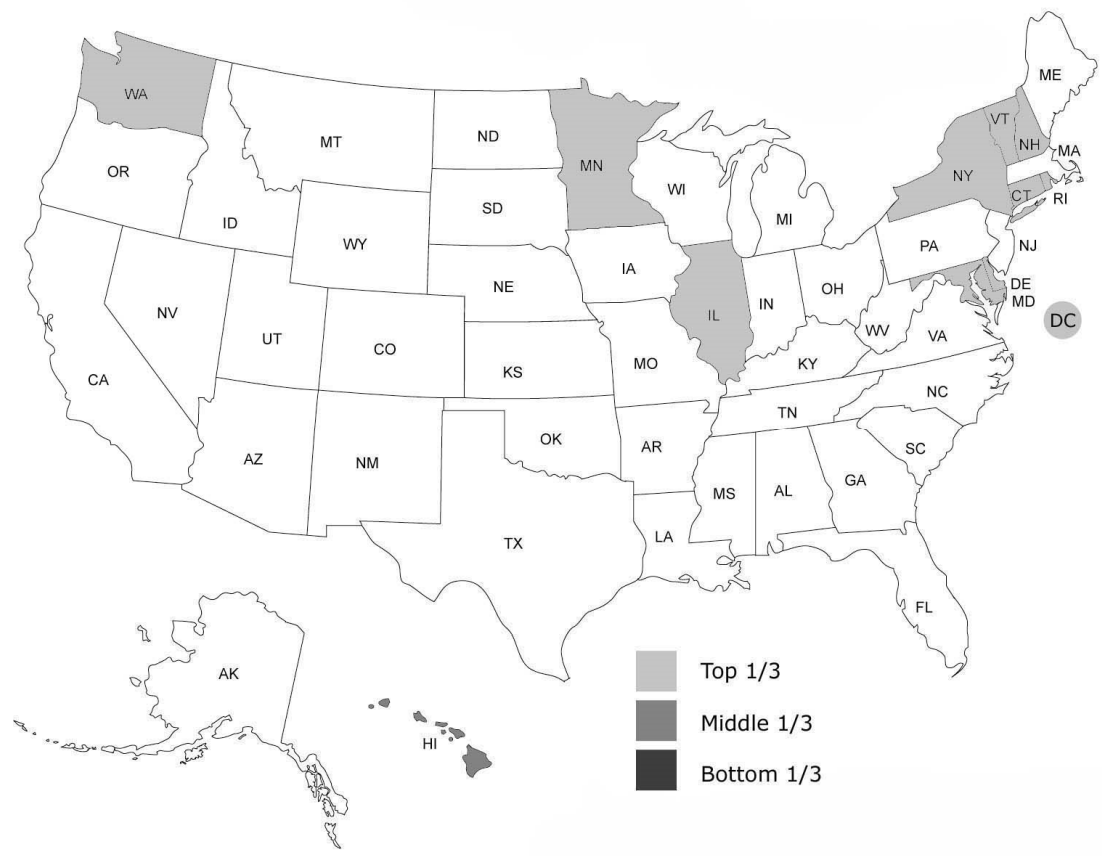

FigURE 14: Ranking of Enacting Jurisdictions by Educational Attainment

The short list of demographic factors posited to influence support for same-sex marriage likely created a favorable environment for same-sex marriage recognition. But existing legal constructs surely favored enactment of marriage equality, too. Some legislators see same-sex marriage legislation as "a reasonable extension"191 of the non-discrimination laws that open access for lesbian, gay, bisexual, and transgender (LGBT) persons to housing, hiring, and public accommodations. ${ }^{192}$ Those same laws provide not just a platform for

191. Religious Liberty Implications of D.C.'s Same-Sex Marriage Bill: Hearing on Bill 18-482 Before the D.C. Council, 19th Sess. (Nov. 2, 2009) (statement of Councilmember Graham at 7:11:18) (on file with author) ("I assume that this is a reasonable extension of the Human Rights Act of the District of Columbia ....").

192. To be clear, it is shameful for a state not to give a basic promise of nondiscrimination in employment, housing, and public accommodations to LGBT people. Many of these laws specifically insulate religious groups from predictable violations of their religious beliefs, like opening married student housing to unmarried couples. See, e.g., N.Y. EXEC. LAW § 290, 292(9) (McKinney 2010) (barring discrimination based on sexual orientation in employment, education, housing, and public accommodations); see also N.Y.C, N.Y., Admin. Code § 8-107(12) (2010) (expressly not barring "any religious or denominational institution or organization or any organization operated for charitable or educational purposes, which is operated, 
same-sex marriage, but a powerful rhetorical argument against religious liberty protections, which some charge will chip away at those protections. Jenny Pizer, senior counsel for Lambda Legal, succinctly captures this contention:

In some states, the price of equality in marriage has been agreeing to give up protections against discrimination as part of the negotiations.... In ways, I think, other politically vulnerable groups are not required to pay that price. ${ }^{193}$

These arguments have resonated with some legislators who say that if same-sex marriage legislation is about "equality, marriage equality" then "the extent to which we keep carving away at its vitality, that's very problematic."194 (Properly understood, religious liberty protections should not be seen as a rollback of prior protections.) $)^{195}$

supervised or controlled by or in connection with a religious organization from ... sales or rental of housing accommodations ... to persons of the same religion or denomination or from making such selection as is calculated by such organization to promote the religious principles for which it is established or maintained").

193. Zoll, supra note 55, at 2 .

Importantly, religious liberty protections appear in hundreds of U.S. and state laws including Title VII of the Civil Rights Act of 1964. See Title VII of the Civil Rights Act of 1964; Michael W. McConnell, The Problem of Singling Out Religion, 50 DePaul L. Rev. 1 (2010) (listing hundreds of laws with accommodations for religious believers). The state's choice to accommodate religious dissenters is not a denial of equality by the state. See Corp. of the Presiding Bishop v. Amos, 483 U.S. 327, 338 (1987) (noting that the Court "has never indicated that statutes that give special consideration to religious groups are per se invalid. That would run contrary to the teaching of our cases that there is ample room for accommodation of religion under the Establishment Clause"). Some have argued that the best doctrinal ground for recognizing same-sex marriage is equal treatment in a fundamental right, rather than pure equality. See Nelson Tebbe \& Deborah A. Widiss, Equal Access and the Right to Marry, 158 U. PA. L. REV. 1375 (2010), available at SSRN: http://ssrn.com/abstract=1594361.

194. See supra note 191 (statement of Councilmember Graham).

195. Religious liberty protections in same-sex marriage laws do not roll back antidiscrimination laws, which "largely address commercial services, like hailing taxis, ordering burgers, and leasing apartments, for which it is hard to imagine that a refusal to serve another individual can reflect anything other than animus toward that individual." Wilson, Calculus, supra note 99 , at 1476 . Unlike those commercial services, facilitating another's marriage is a religiously freighted and deeply personal matter, where a denial can reflect something other than animus towards another individual. Because many nondiscrimination laws were passed decades before same-sex marriage was permitted anywhere in the world, those laws could not have foreseen application to such a deeply religious service like facilitating another's marriage. See, e.g., Title II of the 1964 Civil Rights Act (prohibiting discrimination in public accommodations on 
Not surprisingly, every Enacting Jurisdiction prohibited sexual orientation discrimination in housing, employment and public accommodations well before recognizing same-sex marriage, as Figure 15 shows. ${ }^{196}$ Some Enacting Jurisdictions also separately prohibited gender identity discrimination. ${ }^{197}$

specified bases, like race). Moreover, the extension by the Enacting Jurisdictions of such general nondiscrimination laws to sexual orientation discrimination occurred in some cases decades before the enactment of same-sex marriage by legislation. See Table A2.

196. For Connecticut, compare Conn. Gen. Stat. § 46b-20a (Apr. 23, 2009) with Conn. Gen. Stat. Ann. § 46a-60 (West 2009); Conn. Gen. Stat. Ann. § 46a-64c (West 2009); Conn. Gen. Stat. § 46a-64 (West 2009); Conn. Gen. Stat. Ann. § 46a-66 (West 2009); Conn. Gen. Stat. AnN. § 46a-75 (West 2009) (prohibiting sexual orientation discrimination in housing, private and public employment, public accommodation, credit, and education); for Delaware, compare H.B. 75, 147th Gen. Assemb. (Del. 2013) (July 1, 2013) with Del. Code Ann. tit. 19, $§ 711$ (West 2013); Del. Code AnN. tit. 6, § 4603 (West 2013); Del. Code AnN. tit. 6, $\$ 4504$ (West 2013) (prohibiting sexual orientation discrimination in housing, public and private employment, and public accommodation); for the District of Columbia, compare D.C. Code § 46-401 (LexisNexis 2012) (March 3, 2010) with D.C. Code § 21402.11 (LexisNexis 2012); D.C. CoDE § 32-408 (LexisNexis 2012); D.C. Code § 2-1402.21 (LexisNexis 2012); D.C. Code § 2-1402.41 (LexisNexis 2012) (prohibiting sexual orientation discrimination in private and public employment, housing, and education); for Hawaii, compare S.B. 1, 27th Leg. 2d Spec. Sess. (Haw. 2013) (Dec. 2, 2013) with Haw. Rev. Stat. § 515-3 (West Supp. 2012); Haw. Rev. Stat. $\S 489-3$ (West Supp 2012) (prohibiting sexual orientation discrimination in housing and public accommodation); for Illinois, compare S.B. 0010, 98th Gen. Assemb. (Ill. 2013) (June 1, 2014) with 775 Ill. Comp. StAT. Ann. 5/1-102(A) (WeSt 2011) (prohibiting sexual orientation discrimination in housing, private and public employment, public accommodation, credit, and education); for Maryland, compare MD. Code Ann., Fam. Law § 2-201 (Jan. 1, 2013) with Md. Code Ann., State Gov'T § 20-606 (LexisNexis Supp. 2013; Md. Code Ann., State Gov't § 20-705 (LexisNexis 2009); Md. Code Ann., State Gov'T § 20-304 (LexisNexis 2009); Md. Code Ann., Educ. § 7-424 (LexisNexis 2008) (prohibiting sexual orientation discrimination in housing, private and public employment, public accommodation, and education); for Minnesota, compare H.F. 1054, 88th Sess. (Minn. 2013) (Aug. 1, 2013) with Minn. Stat. Ann. § 363A.08, SubD. 2 (West 2012), Minn. Stat. Ann. § 363A.09 (West 2012), Minn. Stat. Ann. $\S 363$ A.11, Subd. 1 (West 2012), Minn. Stat. Ann. § 363A.16 (West 2012), subd. 1, Minn. Stat. Ann. § 363A.13 (West 2012) (prohibiting sexual orientation discrimination in housing, private and public employment, public accommodation, credit, and education); for New Hampshire, compare N.H. Rev. Stat. § 457:1-A (Jan. 1, 2010) with N.H. Rev. Stat. § 354-A:6 (2009), N.H. Rev. Stat. § 354-A:8 (2009), N.H. Rev. Stat. § 354-A:10 (2009), N.H. Rev. Stat. Ann. $\S$ 354-A:16 (2009); N.H. Rev. Stat. Ann. § 354-A:17 (2009) (prohibiting sexual orientation discrimination in housing, private and public employment, and public accommodation); for New York, 
compare N.Y. Dom. ReL. LAW § 10-a (McKinney Supp. 2014) (enacted July 24, 2011) with N.Y. ExEC. LAW § 296 (McKinney 2013); N.Y. EXEC. LAW § 296-a (McKinney 2013) (prohibiting sexual orientation discrimination in housing, private and public employment, public accommodation, credit, and education); for Rhode Island, compare H.B. 5015B, 2013 Reg. Sess. (R.I. 2013) (codified at R.I. GEN. Laws § 15-1-1 (2013)) with R.I. Gen. Laws § 28-5-7 (2003); R.I. Gen. Laws § 3437-4 (2011); R.I. Gen. Laws § 11-24-2 (2002); R.I. Gen. Laws $\S 28-5.1-8$ (Supp. 2013) (prohibiting sexual orientation discrimination in housing, private and public employment, public accommodation, and education); for Vermont, compare VT. STAT. AnN. tit. 15, § 8 (Sept. 1, 2009) with Vt. Stat. Ann. tit. 21, § 495(a), Vt. Stat. Ann. tit. 9, $\S 4503$ (Supp. 2013); Vt. Stat. Ann. tit. 9, § 4502(a) (Supp. 2013); Vt. Stat. Ann. tit. 8, § 10403 (Supp. 2013); Vt. Stat. Ann. tit. 16, $\S 11$ (Supp. 2013); VT. Stat. AnN. tit. 16, § 565 (Supp. 2011) (prohibiting sexual orientation discrimination in housing, private and public employment, public accommodation, credit, and education); for Washington, compare WASH. REv. CODE § 26.04.010(1) (LexisNexis 2013) (enacted Dec. 6, 2012) with WAsh. Rev. CodE § 49.60.180 (2012); Wash. Rev. Code § 49.60.222 (2012); Wash. Rev. Code $\S 49.60 .215$ (2012); Wash. Rev. Code $\S$ 49.60.175 (2012); Wash. REv. CODE $\S$ 49.60.040(2) (2012) (prohibiting sexual orientation discrimination in housing, private and public employment, public accommodation, credit, and education). See also States with Protections for Being Gay, N.Y. Times (May 31, 2013) available at http://www.nytimes.com/interactive/2013/05/31/business/States-WithProtections-for-Being-Gay.html?ref=your-money.; Colo. Rev. Stat. AnN. §§ 24-34-401-402 (2013); IowA Code AnN. § 216.6 (West 2009); Me. Rev. Stat. Ann. tit. 5, § 4553 (2013); Mass. Gen. Laws Ann. ch. 151B, § 4 (West 2013); Nev. Rev. Stat. § 281.370 (West 2013); N.J. Stat. Ann. 10:1-1-10:1-3 (West 2013); N.M. Stat. Ann. § 28-1-2 (2012); N.M. Stat. Ann. § 28-1-7 (2012); N.M. Stat. Ann. § 28-1-9 (2012); Or. Rev. Stat. § 659A.030 (2013); Wis. Stat. Ann. $\S 111.31(2)$ (West Supp. 2013). See Table A2 for a calculation of how long the earliest nondiscrimination ban in statewide law preceded samesex marriage in each Enacting Jurisdiction.

197. See generally Inst. of Real Estate Mgmt., Laws Prohibiting Discrimination Based On Sexual Orientation And Gender IDENTITY, ( 2013). 


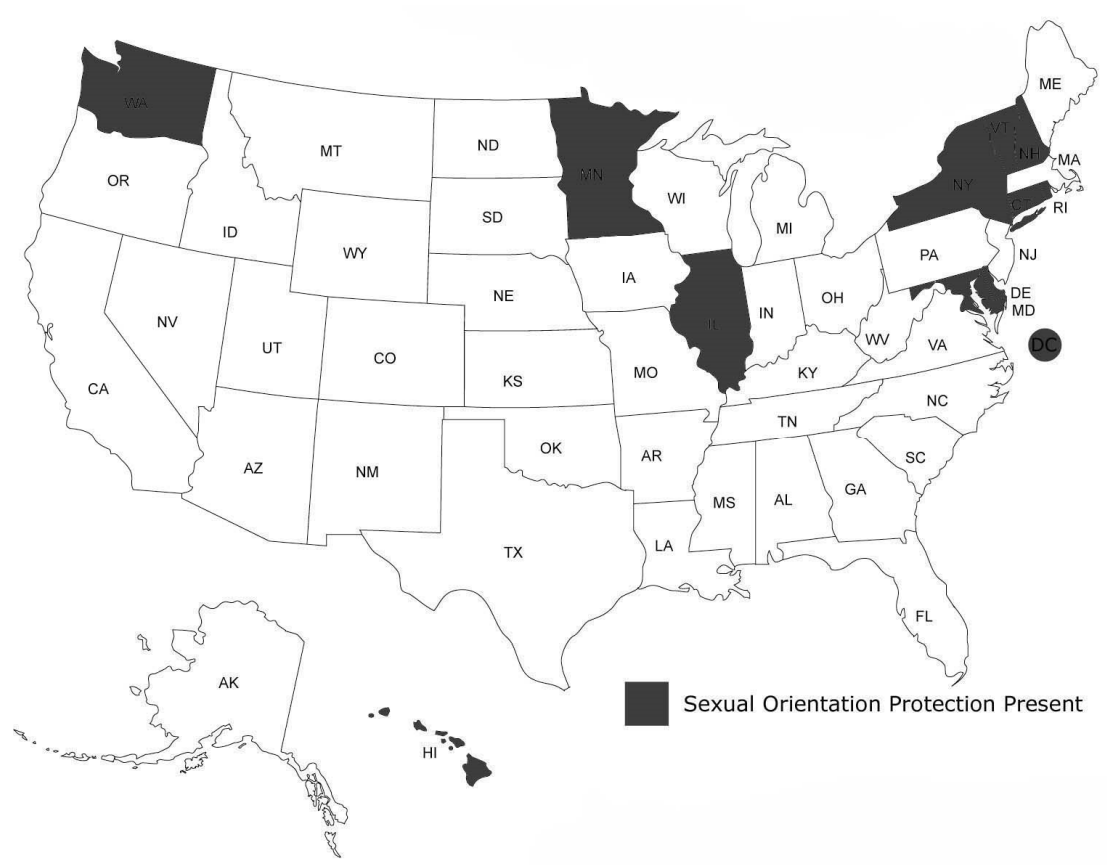

Figure 15: Sexual Orientation Protection at Time of Same-Sex Marriage Legislation

Leveraging a "perfect storm" of demographic variables, public support, and preexisting legal constructs, supporters succeeded in securing same-sex marriage in the Enacting Jurisdictions with modest religious liberty protections. Absent those protections, same-sex marriage surely would have been forthcoming, with or without protections, in a few short years.

\section{The Political Terrain Going Forward}

So what does a die-hard opponent of same-sex marriage do in the face of these trends? What do the trends mean for those who are pursing marriage equality? Putting aside game-changing judicial decisions ${ }^{198}$ Professor Laycock rightly concludes that opponents, who are "losing this fight... need to get some more liberty protections while they have a chance. Once a law is passed, it's too late." ${ }^{199}$ But, same-sex marriage advocates should continue to bargain as well because the movement has nearly exhausted states with high support

198. See supra note 63 (discussing New Jersey's judicial decision).

199. Zylstra, supra note 104. 
for same-sex marriage and favorable political terrain, ${ }^{200}$ and it remains uncertain when and if the U.S. Supreme Court will take a marriage equality case. ${ }^{201}$

But unlike the Enacting Jurisdictions, in the thirty-one Nonrecognizing States ${ }^{202}$ the characteristics favoring marriage equality fragment. In more difficult political terrain, especially states in which legislators are accountable to more "very religious" people, one might reasonably expect that legislators will tip the balance between marriage equality and religious liberty in favor of religious objectors.

Here, the "perfect storm" works against an easier victory for same-sex marriage advocates, placing a premium on bargaining. As Figure 16 demonstrates, in the thirty-one Nonrecognizing States, Democrats control only three legislatures. Republicans control the legislature in twenty-five states and split control in three others. ${ }^{203}$

200. Religious liberty advocates in the near term can deliver precious votes for same-sex marriage. Marriage equality proponents benefit from samesex marriage with religious liberty protections when the alternative is no marriage, at least for now.

201. See supra note 58 (discussing the importance of meaningful circuit splits).

202. The discussion of political climate in Part III backs out Utah and Oklahoma since lower federal court decisions striking the constitutional bans on same-sex marriage in those states occurred before the date cutoff for the snapshot of state marriage laws on January 14, 2014, even though the decisions were stayed. See supra notes $4-5$. New Jersey and New Mexico also recognized same-sex marriage by a dispositive judicial decision before January 14, 2014, and so are also not considered in Part III. See supra note 8.

203. See Table A4. Compare Figure 16 with Figure 11. 


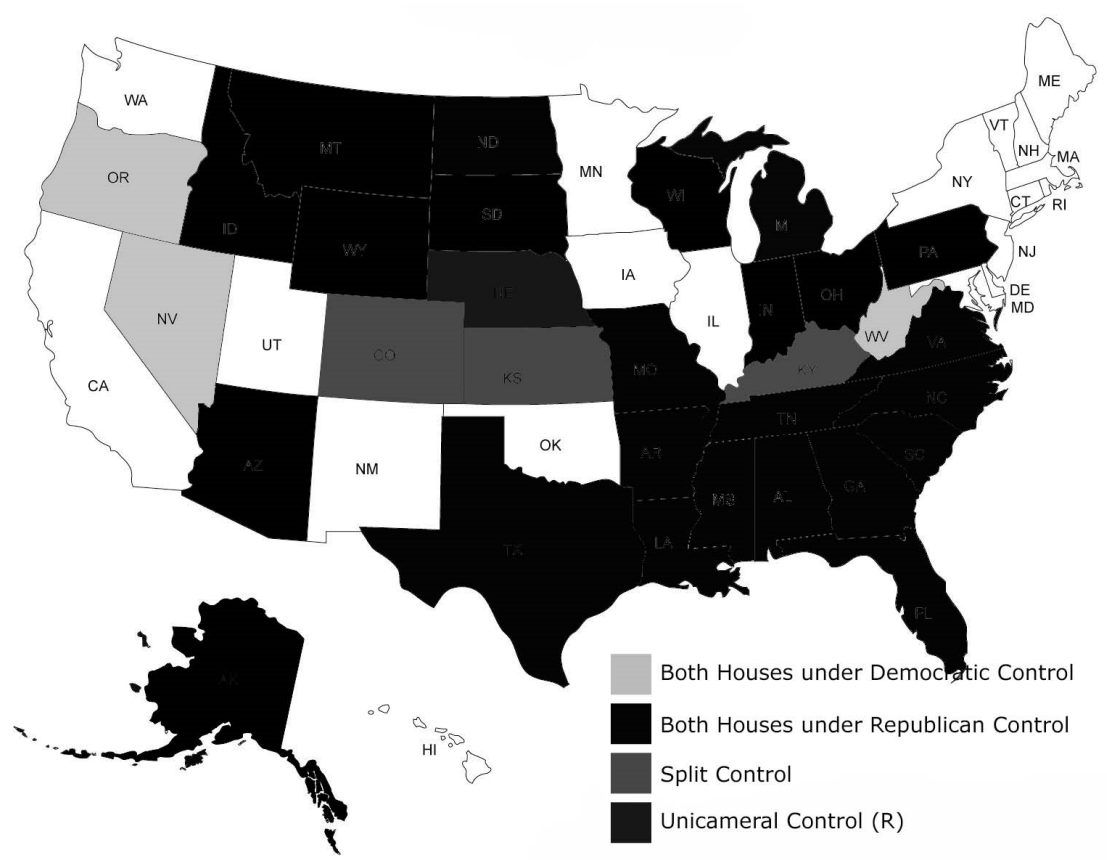

Figure 16: Legislative Control of States That Do Not Permit Same-Sex Marriage (2013)

Figure 17 shows that in the Nonrecognizing States only seven governors as of October 22, 2013, are members of the Democratic Party. Republicans occupy the governor's mansion in remaining twenty-four states. ${ }^{204}$

204. See Table A4. Compare Figure 17 with Figure 12. See infra note 232 for a discussion of changes in control of the governor's office since the Symposium date. 


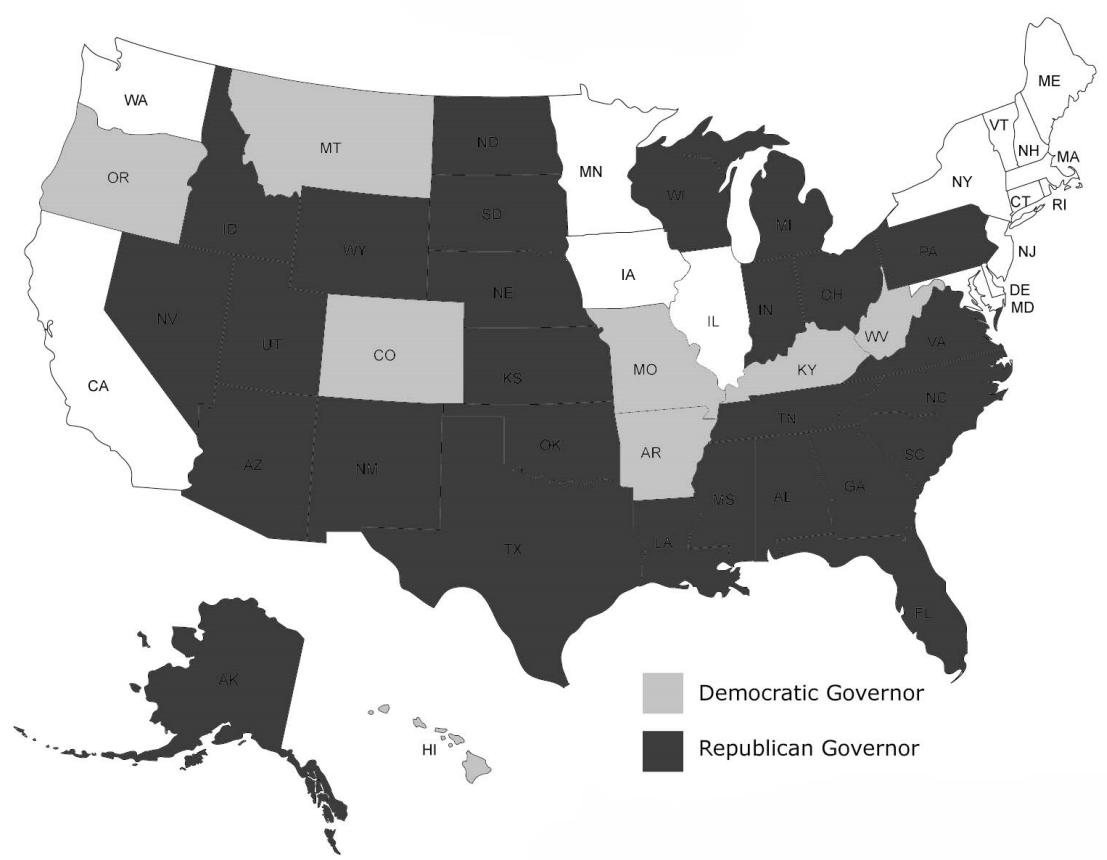

Figure 17: Party of Governor in States That Do Not Permit Same-Sex Marriage (2013)

In addition to being largely Republican-controlled, the Nonrecognizing States have more religious constituents. ${ }^{205}$ As Figure 18 shows, only six of the Nonrecognizing States rank in the bottom third for religiosity. Twenty-five of the Nonrecognizing States rank in either the top or middle third. ${ }^{206}$

205. See Table A4. Compare Figure18 with Figure 13.

206. Not surprisingly, thirteen of the Non-recognizing states have RFRAs. See Ariz. Rev. Stat. Ann. $\S$ 41-1493 to -1493.02 (2009); Fla. Stat. AnN. §§761.01-.05 (West 2010); IDAHO CODE AnN. §§ 73-401 to -404 (2009); Kan. Stat. Ann. §§ 60-5301-5305; Ky. Rev. Stat. Ann. $\S 446.350$ (2013); La. Rev. Stat. §§ 13:5231-5242 (2010); Mo. AnN. Stat. $\S 1.302-.307$ (West 2010); 71 Pa. Cons. Stat. AnN. §§ 24012407 (West 2009); S.C. Code Ann. §§ 1-32-10 to -60 (2010); Tenn. Code Ann. § 4-1-407 (2009); Tex. Civ. Prac. \& Rem. Code Ann. $\S \S 110.001-.012$ (Vernon 2009); VA. CodE ANN. §§ 57-1 to -2.02 (2009). Alabama's state constitution subjects state law burdening religious practice to heightened scrutiny. See Ala. Const. art. I, § 3.01.

Of the states with recent judicial decisions requiring same-sex marriage, New Mexico and Oklahoma have RFRAs. See N.M. Stat. Ann. §§ 28-221 to 28-22-5 (2006); Okla. Stat. Ann. tit. 51, §§ 251-258 (West 2010). 


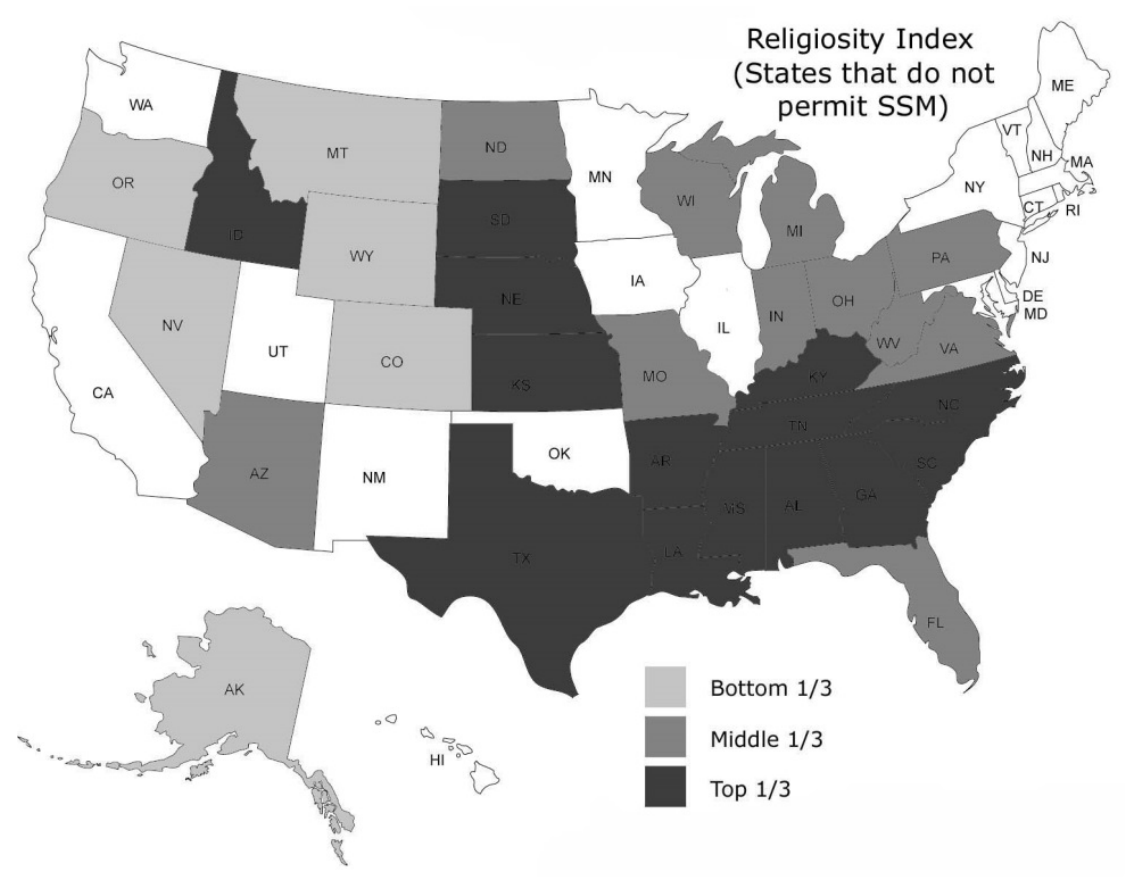

Figure 18: Religiosity Index for States That Do Not Permit Same-Sex Marriage

Figure 19 shows that the levels of formal education in the Nonrecognizing States is strikingly lower in than the Enacting Jurisdictions. ${ }^{207}$ While three states rank in the top tier, as nearly every Enacting Jurisdiction did, twenty-eight Nonrecognizing States rank in the bottom two-thirds for educational attainment. Only Colorado, Virginia, and Oregon defy this trend. 


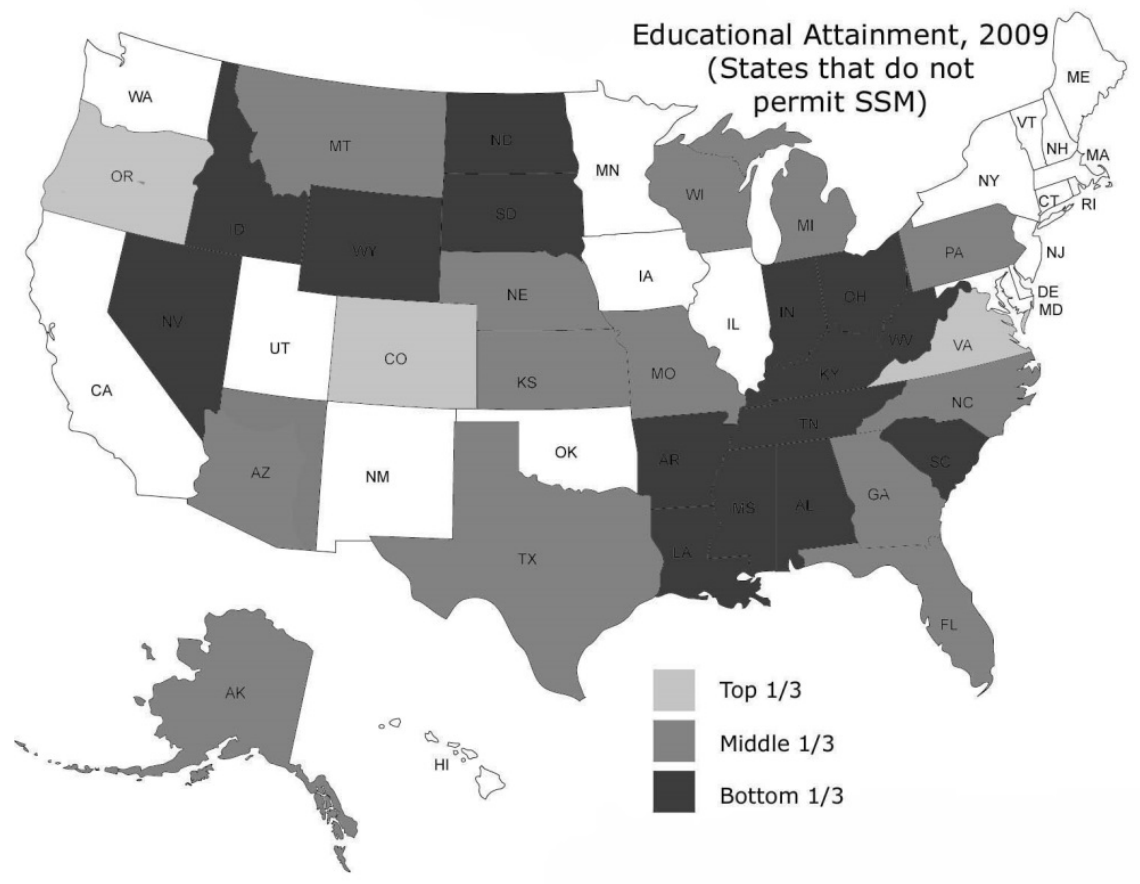

Figure 19: Educational Attainment for States That Do Not Permit Same-Sex Marriage

Finally, same-sex marriage advocates will not have a background promise of non-discrimination working in their favor. Figure 20 shows that only a handful of remaining states, four, prohibit discrimination on the basis of sexual orientation in housing, hiring, and public accommodations. ${ }^{208}$ The absence of a statewide guarantee of

208. Colo. Rev. Stat. § 24-34-402 (2013); Colo. Rev. Stat. § 24-34-502 (2013); Colo. Rev. Stat. § 24-34-601 (2013); Colo. Rev. Stat. § 1259-106(1)(s) (2013) (prohibiting discrimination in private and public employment, housing, public accommodations, and education); NEv. Rev. Stat. § 613.330 (2012); Nev. Rev. Stat. § 118.020 (Supp. 2013); Nev. Rev. Stat. § 651.070 (West Supp. 2013) (prohibiting discrimination in private and public employment, housing, and public accommodations); Or. Rev. Stat. § 659A.030 (2013); Or. Rev. Stat. $\S$ 659A.421 (2013); Or. Rev. Stat. § 659A.403 (2013); Or. Rev. STAT. § 659.850(2) (2013) (prohibiting discrimination in private and public employment, housing, public accommodations, and education); Wis. Stat. Ann. § 111.31(2) (West Supp. 2013); Wis. Stat. Ann. § 106.50 (West Supp. 2013); Wis. Stat. AnN. § 106.52 (West Supp. 2013); Wis. Stat. AnN. § 36.12 (West 2013) (prohibiting discrimination in private and public employment, housing, public accommodations, and education). Of these states, only Wisconsin does not also prohibit gender identity discrimination. Presumably, a state 
nondiscrimination is significant: it means that legislators crafting accommodations for same-sex marriage will be writing on a blank slate when deciding how little latitude - or how much - to give religious dissenters. If nothing in state or local law prohibits discrimination on the basis of sexual orientation or marital status, religious dissenters will not need religious liberty protections. Legislators interested in providing greater protections will not be

legislator weighing religious liberty exemptions is concerned only about rolling back protections for which they are accountable.

Other laws can provide important protections for LGBT individuals. Some states ban sexual orientation discrimination by public employers, like Indiana, Michigan, Montana, and Pennsylvania. See http://employment.findlaw.com/employment-discrimination/sexualorientation-discrimination-in-the-workplace.html\#sthash.T1frmnwH.

dpuf. Executive Orders in some Nonrecognizing States do bar discrimination against public employees on the basis of sexual orientation. See, e.g., Mo. Exec. Order No. 10-24 (July 9, 2010) http: //governor.mo.gov/orders/2010/10-24.htm; Va. Exec. Directive No. 1 (2010) http://www.dhrm.virginia.gov/documents/ExecutiveDirective One.pdf. These states are treated here as not providing state-wide protection against sexual orientation discrimination.

Further, in states that lack statewide nondiscrimination bans, "[m]unicipal law provides powerful protections" in many localities. Municipal Equality Index: A Nationwide Evaluation of Municipal Law Human Rights CAMPAign (2013), available at: http://www.hrc.org/ files/assets/resources/MEI_2013_report.pdf.

Because the number of municipalities providing such protections varies dramatically from state to state, localized protections are also not factored in, although they provide an important source of redress for LGBT individuals. Compare Arizona where municipal nondiscrimination bans cover only Phoenix with Nevada, where nondiscrimination bans covering all major cities. See $i d$. Some states, while providing no promise of non-discrimination on the basis of sexual orientation, do provide special protection based on sexual orientation in state hate crime laws. For example, Texas has some protection built into their hate crime statutes. See Act of June 19, 1993, ch. 987, 1993 Tex. Gen. Laws $\S 4$ (codified as amended in scattered sections of the Texas Penal Code and the Texas Code of Criminal Procedure); Act of May 11, 2001, ch. 85, 2001 Tex. Gen. Laws $\S 1.02$ (codified as amended in scattered sections of the Texas Penal Code, the Texas Education Code, the Texas Government Code, and the Texas Code of Criminal Procedure). In particular, Texas's 2001 hate crime statute requires that, in a criminal trial, the trier of fact determines if the defendant acted on basis or prejudice against a number of different classifications including sexual preference, $i d$, at $\S 1.02,2001$ Tex. Gen. Laws at $\S 1.01$ (codified as Tex. Code Crim. Proc. Ann. art. 42.014 (West 2014)) and increases the punishment if the trier of fact finds such prejudice, Act of June 19, 1993, § 1, 1993 Tex. Gen.Laws at $\S 1$ (codified as amended at Tex. Penal Code Ann. $\$ 12.47$ (West 2014)). Further, a state legislator weighing religious liberty exemptions presumably is concerned only about rolling back protections the state impressed into law. 
subject to the claim - which has swayed some elsewhere - that religious liberty protections in the same-sex marriage law will "roll back" existing LGBT protections. ${ }^{209}$

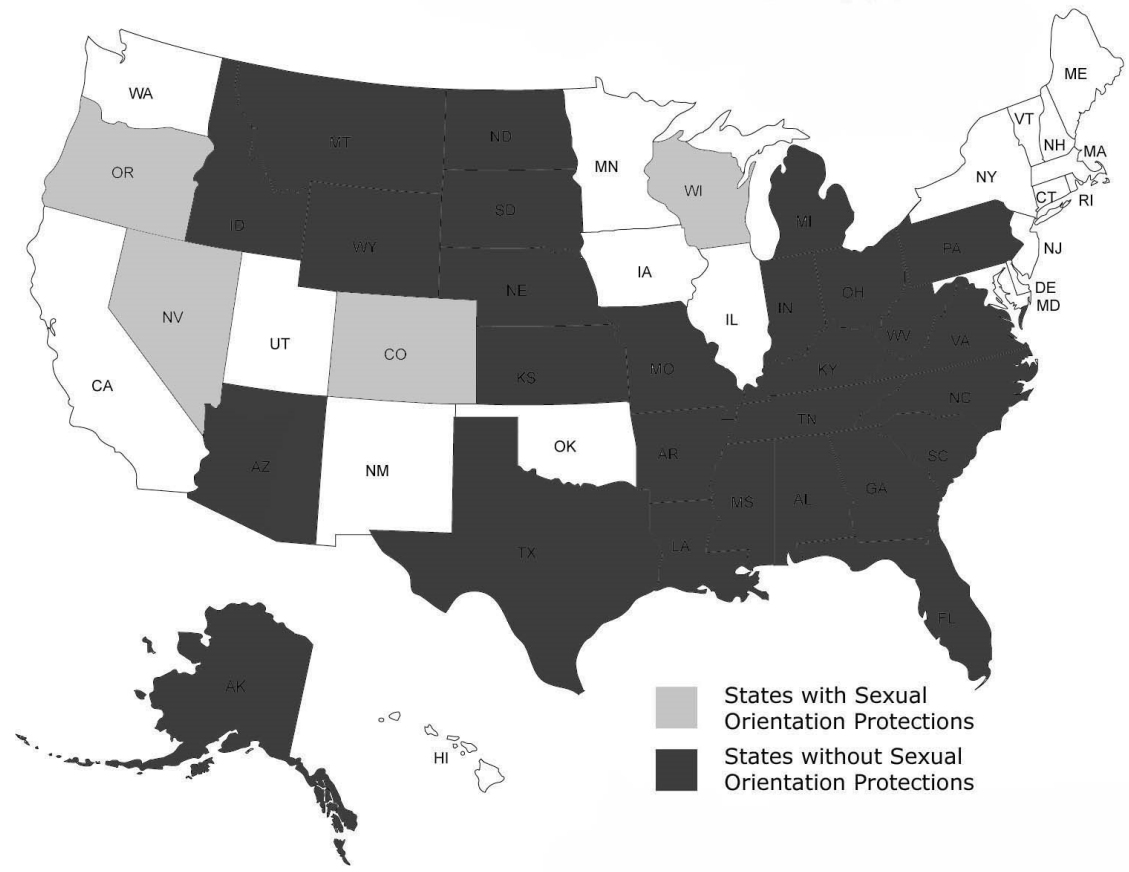

Figure 20: Sexual Orientation Protections in State-Wide Law

Not only do the remaining states not offer statewide nondiscrimination guarantees, nearly all of the remaining states ban same-sex marriage in the state constitution. As Figure 21 shows, in twenty-seven Nonrecognizing States the state constitution presently bars same-sex marriage. ${ }^{210}$ Only the constitutions of Wyoming,

209. See supra note 180 (describing the force of this idea and why it should not be seen as rolling back protections).

210. Ala. Const. art. I, § 36.03; Alaska Const. art. I, § 25; Ariz. Const. art. XXX, § 1; Ark. Const. amend. LXXXIII, § 1; Colo. Const. art. II, § 31; Fla. Const. art. I, § 27; Idaho Const. art. III, § 28; Kan. Const. art. XV, § 16; KY. Const. § 233a; LA. Const. art. XII, § 15; Mich. Const. art. I, $\S 25$; Miss. Const. art. XIV, $\S 263 \mathrm{~A} ;$ Mo. Const. art. I, § 33; Mont. Const. art. XIII, § 7; NeB. Const. art. I, § 29; Nev. Const. art. I, § 21; N.C. Const. art. XIV, § 6; N.D. Const. art. XI, § 28; Ohio Const. art. XV, § 11; Or. Const. art. XV, § 5a; S.C. Const. art. XVII, § 15; S.D. Const. art. XXI, § 9; Tenn. Const. art. XI, § 18; Tex. Const. art. I, § 32; VA. Const. art. I, § 15-A; WIS. Const. art. XIII, § 13. Utah's and Oklahoma's bans have been invalidated by federal district courts although the decisions are currently stayed. OKLA. Const. art. II, § 35; Utah Const. art. I, § 29. 
Indiana, West Virginia, and Pennsylvania do not ban same-sex marriage. ${ }^{211}$

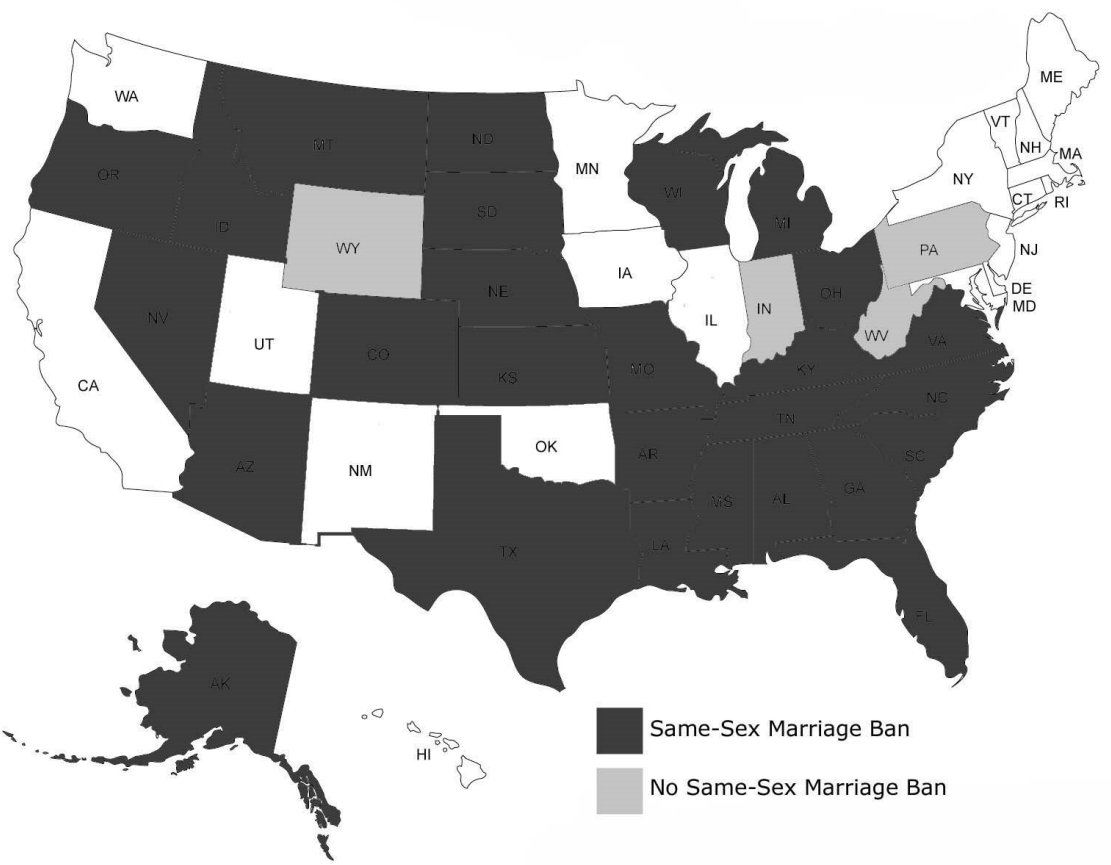

Figure 21: Same-Sex Marriage Banned in State Constitution

Some of the constitutional bans have been challenged, but ultimately were left in place. See Citizens for Equal Prot. v. Bruning, 455 F.3d 859 (8th Cir. 2006) (upholding Nebraska's state conditional ban on same-sex marriage against a federal constitutional challenge). A number of challenges to state constitutional bans are pending across the country. See Jillian Rayfield, 4 Pivotal Gay Rights Court Cases You Should Know About: The U.S. Judicial System Has Become the Main Battlefield in the Fight for Equal Rights, The WeEk (Jan. 28, 2014) available at: http://theweek.com/article/index/255595/4-pivotal-gayrights-court-cases-that-you-should-know-about (discussing challenges in Virginia, Michigan, Pennsylvania, and Ohio).

211. The remaining Nonrecognizing States all ban same-sex marriage by statute. See, e.g., IND. CODE ANN. § 31-11-1-1 (West 2008) (making same-sex marriage unlawful in Indiana and refusing to recognize out-ofstate marriages); 23 PA. Cons. Stat. Ann. § 1704 (West 2010) (defining marriage as between one man and one woman); W. VA. CodE ANN. §48-2-104 (LexisNexis 2009) (defining marriage as a lifelong union between a woman and a man); Wyo. Stat. AnN. § 20-1-101 (2013) (defining marriage as a civil contract between a male and female person). Unlike a constitutional ban, the statutory ban poses no special hurdles to removal of the ban. 
In light of the state constitutional bans, some opponents might resist any bargain over same-sex marriage, believing that the outcome they seek - no same-sex marriage - is already in effect. However, state constitutional bans are not all set in stone, as Part V shows.

Those states in which the populous is highly supportive of samesex marriage are no longer in play. As Figure 22 shows, in 2012, six of the Nonrecognizing States were deeply opposed to same-sex marriage, showing support less than $40 \%$. In an additional twenty Nonrecognizing States, a majority of the populace simply does not support same-sex marriage.

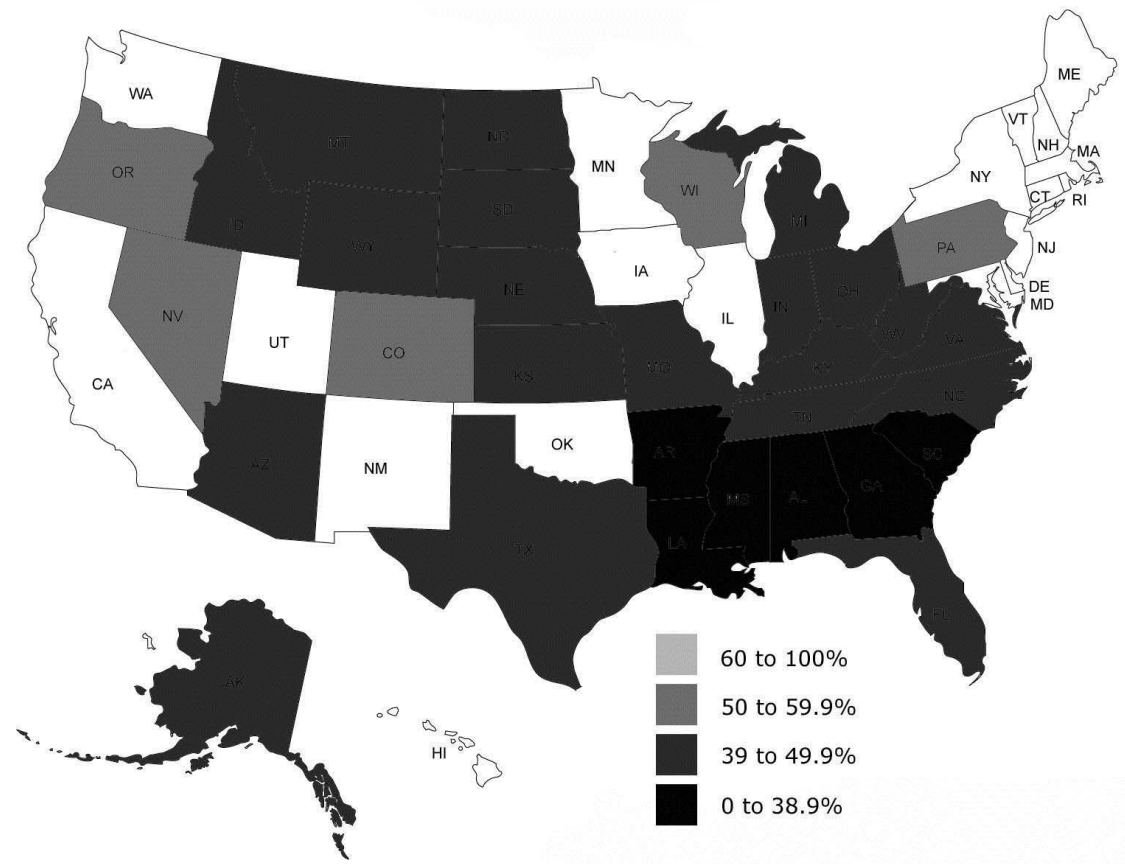

Figure 22: Support for Same-Sex Marriage in States That Do Not Permit Same-Sex Marriage

The extent to which religious liberty protections will influence the fate of same-sex marriage in any given state likely will depend on a complicated interplay of preexisting nondiscrimination law, state constitutional prohibitions, popular support, legislative control, education, and religiosity, as well as a host of other factors, including 
pending constitutional litigation in state and federal courts, ${ }^{212}$ and even the personal convictions of individual legislators. ${ }^{213}$

\section{Difficult Terrain Does not Mean Opponents Can Hold OUT}

Same-sex marriage opponents face the real fork in the road: Should they oppose same-sex marriage to the bitter end or take a more pragmatic approach and bargain now, trading marriage equality for "substantial protections for religious dissenters[?]"14 For some opponents (and supporters), the fight over same-sex marriage is an existential one, making it unthinkable to compromise. ${ }^{215}$ For others,

212. As of February 2014, 42 suits challenging marriage bans were pending across U.S. See David Cruz at UC Davis Law Review Symposium (February 7, 2014) (citing James Esseks of the ACLU).

213. See supra notes 21, 24, 29 (providing interviews with individual legislators, such as Hawaii Representative Jo Jordan of Hawaii).

214. Dreher, supra note 40 , at 15 . Some vow to stay focused on fighting same-sex marriage on the merits, rather than actively (and exclusively) seeking religious liberty protections. See supra note 40. Some opponents do not see these approaches as an "either-or." Caleb Dalton, an attorney for the Alliance Defending Freedom, says:

We will continue to advocate for marriage between one man and one woman as the building block of society. But in cases where a state has chosen to redefine its marriage laws, we support the active inclusion of robust religious liberty protections in pending legislation.

Id. Russell Moore, president of the Southern Baptist Convention's Ethics and Religious Liberty Commission, echoed the sentiment:

So while we're fighting for religious liberty, we're articulating why we believe marriage is significant and important. And while we're fighting for marriage, we're articulating why the religious liberty concerns that inevitably come from these discussions are significant. . . . We do both, and we don't abandon or marginalize either plank.

$I d$.

215. See Matthew J. Franck, "Is Sex Just Like Race?," The Public Discourse (July 8, 2011), http://www.thepublicdiscourse.com/2011/ $07 / 3520$ ("Today it is those claiming a specious 'freedom to marry' who make a claim at odds with the institution's nature and alien to its purposes. It is they who would instrumentalize it by a redefinition, a destroying and remaking, that puts marriage to a new kind of work in the service of state policy.").

On this issue, like other deeply divisive issues, the most strident voices on each side sometimes gain by seeking a total win, because it rallies their base. Surely some people in this fight benefit from continuing to oppose compromise. A perverse conflict of interest can arise because compromise turns down the temperature on an issue. See Sally 
central tenets of their faith tradition direct them not to compromise on the particular question of marriage equality. ${ }^{216}$ But for those who may be swayed by pragmatic arguments, ${ }^{217}$ a clear-eyed view of the benefits of compromise is important. ${ }^{218}$ Arguably, the strongest reason not to compromise is that voters have foreclosed same-sex marriage by state constitutional amendment in twenty-seven states. ${ }^{219}$ But

Steenland, Return of the Culture Wars: Tea Party's Social and Religious Agenda and How Progressives Can Respond (Nov. 29, 2010), available at http://www.americanprogress.org/issues/religion/news/ 2010/11/29/8601/return-of-the-culture-wars-tea-partys-social-andreligious-agenda-and-how-progressives-can-respond/29292010).

216. For example, a Vatican document instructs:

$[W]$ here a matter of the common good is concerned, it is inappropriate for Church authorities to endorse or remain neutral toward adverse legislation even if it grants exceptions to Church organizations and institutions. The Church has the responsibility to promote family life and the public morality of the entire civil society on the basis of fundamental moral values, not simply to protect herself from the application of harmful laws (cf. no. 17).

Congregation for the Doctrine of the Faith, Some Considerations Concerning the Response to Legislative Proposals on the NonDiscrimination of Homosexual Persons (July 24, 1992), http://www.vatican.va/roman_curia/congregations/cfaith/documents/r c_con_cfaith_doc_19920724_homosexual-persons_en.html.

217. Commentator Rod Dreher believes that a "consensus is emerging . . . that the most important goal ... [is] to secure as much liberty as possible for dissenting religious and social conservatives while there is still time." Dreher, supra note 40, at 12. Dreher likely is premature about the existence of a consensus.

218. Professor Douglas Laycock argues that "conservative churches would do well to concede the liberty of the other side, including on same-sex marriage, and concentrate on defending their own liberty as conscientious objectors; and similarly, that supporters of rights to abortion, contraception, gay rights, and same-sex marriage would do well to concentrate on securing their own rights and to concede that conscientious objectors should rarely be required to support or facilitate practices they view as evil." See Douglas Laycock, Religious Liberty and the Culture Wars, U. ILL. L. REV. (forthcoming 2014) (manuscript at 1); see also Thomas C. Berg, Progressive Arguments for Religious Organizational Freedom: Reflections on the HHS Mandate, J. Contemp. Legal Issues (2013); U. of St. Thomas (Minnesota) Legal Studies Research Paper No. 13-20. Available at SSRN: http://ssrn.com/abstract $=2268824$ or http://dx.doi.org/10.2139/ssrn . 2268824 (arguing that religious freedom is important and that there is value in the social-service contributions of religious nonprofits).

219. See Rex W. Huppke, Lawsuits filed in Cook County claiming state's same-sex marriage ban unconstitutional, The Chicago Tribune (May 31, 2012) ("31 states have amended their constitutions to ban gay marriage."). This tally included California's invalidated Proposition 8. 
unlike the U.S. Constitution, which cannot be amended without great difficulty, many state constitutions do no erect momentous barriers to change.

To undo a constitutional ban, some states require a supermajority (60\% or more) of legislators, followed by a majority of voters, to make any change, creating a strong lock-in effect. Consider, for example, Texas, which requires two-thirds of state legislators in both houses to pass the amendment, after which a simple majority of the electorate must also approve it. ${ }^{220}$ In some of these states, an elaborate convention method also permits amendment, but still nonetheless requires a super-majority of the legislature. Seven of the Nonrecognizing States erect significant barriers to amendment, and therefore significant barriers to repeal (Georgia, Idaho, Kansas, Louisiana, North Carolina, South Carolina, and Texas). ${ }^{221}$ Because

See Chris Cillizza and Sean Sullivan, How Proposition 8 Passed in California-and Why It Wouldn't Today, WAsh. Post (Mar. 26, 2013), http://www.washingtonpost.com/blogs/the-fix/wp/2013/03/26 /how-proposition-8-passed-in-california-and-why-it-wouldnt-today/

(discussing the history and background of California's Proposition 8). Hawaii was included among the thirty-one, but its constitutional amendment, which permitted the legislature to "reserve marriage to opposite sex couples," is now mooted. See HAw. Const. art. I, § 23 ("The legislature shall have the power to reserve marriage to oppositesex couples.").

220. Tex. Const. art. XVII, § 1.

221. See GA. Const. art. X, § 1, para. 1-6 (Legislative Method: requires 2/3 vote of both houses of the legislature and then a simple majority of the electorate; Convention Method: a convention can only be called by a $2 / 3$ vote of both houses of the legislature); IDAHO Const. art. XX, § 13 (Legislative method: requires $2 / 3$ vote of both houses of the legislature and then a simple majority of the electorate. Convention Method: a convention can only be called by a $2 / 3$ vote of both houses of the legislature affirmed by a majority of the electorate); KAN. CONST. art. XIV , § 1-2 (Legislative method: requires $2 / 3$ vote of both houses of the legislature and then a simple majority of the electorate. Convention Method: a convention can only be called by a $2 / 3$ vote of both houses of the legislature affirmed by a majority of the electorate); LA. CONST. art. XIII, § 1-3 (Legislative Method: requires 2/3 vote of both houses of the legislature and then a simple majority of the electorate. Convention Method: a convention can only be called by a $2 / 3$ vote of both houses of the legislature); N.C. Const. art. XIII, § 1-4 (Legislative Method: requires $3 / 5$ vote of both houses of the legislature and then a simple majority of the electorate. Convention Method: a convention can only be called by a $2 / 3$ vote of both houses of the legislature and then any amendment arising out of a convention must be approved by a simple majority of voters); S.C. Const. art. XVI, § 1-3 (Legislative Method: requires $2 / 3$ vote of both houses of the legislature and then a simple majority of the electorate. Convention Method: a convention can only be called by a $2 / 3$ vote of both houses of the legislature affirmed by a majority of the electorate); TEx. Const. art. XVII, § 1 (Legislative method: requires $2 / 3$ vote of both houses of the legislature and then a 
this process is so onerous, once an amendment is adopted, it cannot easily be undone.

In another eight states, constitutional bans enjoy a mild lock-in effect. Alabama, Alaska, Kentucky, Nevada, Oregon, Tennessee, Virginia, and Wisconsin erect some barriers to repeal, but not ones as daunting as Texas'.222 Generally, these states provide a legislative method for amendment, requiring only a majority of legislators and a majority of voters to amend the state's constitution. Some of these states also allow amendments by a periodic convention that either (a)

simple majority of the electorate). Utah's same-sex marriage ban was invalidated but would have exerted a strong lock-in effect. See UTAH Const. art. XXIII, $\S 1-3$ (Legislative method: requires $2 / 3$ vote of both houses of the legislature and then a simple majority of the electorate. Convention Method: a convention can only be called by a $2 / 3$ vote of both houses of the legislature affirmed by a majority of the electorate).

222. See AlA. Const. art. XVIII, § 284-287 (Legislative Method: requires $3 / 5$ vote of both houses of the legislature and then a simple majority of the electorate. Convention Method: a simple majority of legislators from both houses plus a simple majority of voters can call a constitutional convention); Alaska Const. art. XIII, § 1-3 (Automatic Submission Method: Every 10 years the voters of Alaska are asked to decide whether or not to hold a constitutional convention. If the majority of voters say they want a constitutional convention, then delegates to that convention are elected during the next general election. Legislative Method: requires $2 / 3$ vote of both houses of the legislature and then a simple majority of the electorate); KY. Const. § 256-263 (Legislative Method: requires $3 / 5$ vote of both houses of the legislature and then a simple majority of the electorate. Convention Method: a convention can be called by a simple majority of legislators in both houses plus a simple majority of voters. Any proposed amendments arising out of the convention must then be approved by a majority of voters); NEv. Const. art. 16, § 1-2 (Legislative Method: Simple majority of legislators from both house plus a simple majority of the electorate. Convention Method: a convention can only be called by a $2 / 3$ vote of both houses of the legislature affirmed by a majority of the electorate); OR. CONST. art. XVII, § 1-2 (Legislative Method: Simple majority of legislators from both house plus a simple majority of the electorate. Legislative Revision Method: the legislature may "revise" all or part of the constitution by a $2 / 3$ vote of both houses. The revision must then be approved by a simple majority of voters); TENN. Const. art. XI, § 3 (Legislative Method: requires $2 / 3$ vote of both houses of the legislature and then a simple majority of the electorate. Convention Method: a convention can be called by a simple majority of legislators in both houses plus a simple majority of voters. Any proposed amendments arising out of the convention must then be approved by a majority of voters); VA. CONST. art. XII, § 1-2 (Legislative Method: Simple majority of legislators from both house plus a simple majority of the electorate. Convention Method: a convention can only be called by a $2 / 3$ vote of both houses of the legislature); Wis. Const. art. $12, \S 1$ (Legislative Method: Simple majority of legislators from both house plus a simple majority of the electorate). 
requires approval by a simple majority of voters, but the convention may be called only after long periods of time (e.g., ten years), or (b) permits a convention to take place after two steps - approval by a majority of legislators and approval by majority of the electorate. Consider, for example, Virginia, which provides two paths to adoption or repeal: the legislative method-requiring approval by a simple majority of legislators in both houses and a simple majority of the electorate - and periodic constitutional conventions called by the Legislature, where voters can approve amendments by a simple majority. ${ }^{223}$ Because amendments can pass without super-majority support in the legislature, this process creates a milder lock-in effect.

Twelve states (Arizona, Arkansas, Colorado, Florida, Michigan, Mississippi, Missouri, Montana, Nebraska, North Dakota, Ohio, and South Dakota) fall in the final category, where constitutional bans can be adopted or repealed with relative ease. ${ }^{224}$ A negligible lock-in

223. VA. Const. art. XII, § 1-2.

224. ArIz. Const. art. XXI, § 1-2 (Legislative Method: Simple majority of legislators from both house plus a simple majority of the electorate. Voter Initiative Method: Petition must be signed by $15 \%$ of the total vote cast for governor in the preceding election. Then the proposed amendment appears on the ballot to be decided by a majority of voters in a general election. Convention Method: a convention can be called by the people by referendum); ARK. Const. art. XIX, § 22 (Legislative Method: Simple majority of legislators from both house plus a simple majority of the electorate); Colo. Const. art. XIX, § 1-2 (Legislative Method: requires $2 / 3$ vote of both houses of the legislature and then a simple majority of the electorate. Convention Method: a convention can only be called by a $2 / 3$ vote of both houses of the legislature affirmed by a majority of the electorate); Fla. Const. art. XI, § 1-5 (Legislative Method: requires 3/5 vote of both houses of the legislature and then $60 \%$ of the electorate. Initiative Method: Signatures of $8 \%$ of total electors voting in the last Presidential election for the question to be placed on the ballot. The ballot initiative is approved by $60 \%$ of voters. Convention Method: A convention can be placed on the ballot if $15 \%$ of voters based on the last Presidential election sign a petition requesting a petition. The issue is then placed on the ballot and a convention is called if a simple majority of voters approve); Mich. Const. art. XII, § 1-3 (Voter Initiative Method: Petition must be signed by $10 \%$ of the total vote cast for governor in the preceding election. Then the proposed amendment appears on the ballot to be decided by a majority of voters in a general election. Automatic Submission Method: Every 16 years the question of whether or not to have a constitutional convention reaches the ballot in a general election. The people can vote to have a constitutional convention by a simple majority. They then can approve the proposed amendments coming out of the convention by a simple majority. Legislative Method: requires $2 / 3$ vote of both houses of the legislature and then a simple majority of the electorate); Miss. Const. art. XV, § 273 (Legislative Method: requires $2 / 3$ vote of both houses of the legislature and then a simple majority of the electorate. Voter Initiative: "An initiative to amend the Constitution may be proposed by a petition signed over a twelve-month period by qualified electors equal in number to at least twelve percent $(12 \%)$ of the 
votes for all candidates for Governor in the last gubernatorial election. The signatures of the qualified electors from any congressional district shall not exceed one-fifth $(1 / 5)$ of the total number of signatures required to qualify an initiative petition for placement upon the ballot."); Mo. Const. art. XII, § $2-3$ (Legislative Method: Simple majority of legislators from both houses plus a simple majority of the electorate. Automatic Submission Method: Every 20 years the question of whether to hold a constitutional convention is placed on the ballot. A convention can be called by a simple majority of the electorate); MonT. Const. art. XIV, § 1-9 (Voter-Initiated Convention Method: $10 \%$ of voters in each of $2 / 5$ ths of the legislative districts must sign a petition for a constitutional convention and submit it to the secretary of state. Automatic Submission Method: Every 20 years the question of whether or not to have a constitutional convention reaches the ballot in a general election. The people can vote to have a constitutional convention by a simple majority. They then can approve the proposed amendments coming out of the convention by a simple majority. Legislative Method: requires $2 / 3$ vote of both houses of the legislature and then a simple majority of the electorate. Legislatively-Initiated Convention Method: a convention can also be called by a $2 / 3$ vote of both houses of the legislature. Voter Initiative: "The people may also propose constitutional amendments by initiative. Petitions including the full text of the proposed amendment shall be signed by at least ten percent of the qualified electors of the state."); NEB. Const. art. XVI, § 1-2 (Legislative Method: requires 3/5 vote of both houses of the legislature and then a simple majority of the electorate. Convention Method: a convention can only be called by a $3 / 5$ vote of both houses of the legislature affirmed by a majority of the electorate); N.D. Const. art. III, § 1-9 (Initiative Method: petitioners must gather signatures equaling $2 \%$ of the resident population at the last federal census for a proposed amendment to make the ballot. After crossing this threshold, the amendment is approved or disapproved by simple majority vote in the general election); OHIO Const. art. XVI, § 1-2; 2 (Legislative Method: requires 3/5 vote of both houses of the legislature and then a simple majority of the electorate. Convention Method: a convention can only be called by a $2 / 3$ vote of both houses of the legislature affirmed by a majority of the electorate. Automatic Submission Method: Every 20 years the voters of Ohio are asked to decide whether or not to hold a constitutional convention. If the majority of voters say they want a constitutional convention, then delegates to that convention are elected during the next general election. The convention delegates then have plenary power to amend the constitution subject only to ratification by the people by a simple majority. Voter Initiative: "The . . . power reserved by the people is designated the initiative, and the signatures of ten per centum of the electors shall be required upon a petition to propose an amendment to the constitution."); S.D. Const. art. XXIII, § 1-3 (Legislative Method: Simple majority of legislators from both houses plus a simple majority of the electorate. Convention Method: A convention may be called by $3 / 4$ of legislators in both houses. Voter Initiative: "An amendment proposed by initiative shall require a petition signed by qualified voters equal in number to at least ten percent of the total votes cast for Governor in the last gubernatorial election.").

Oklahoma's same-sex marriage ban was invalidated but would have exerted a negligible lock-in effect. See also OkLA. Const. art. 24, § 1-3 (Legislative Method: requires $2 / 3$ vote of both houses of the legislature 
state permits change with only a small fraction of voters petitioning for it followed up with a simple majority of voters voting in support of the amendment. Typically, the states require $10 \%$ of the electorate to initiate the process, but may range as low as $4 \%$ and as high as $15 \% .{ }^{225}$ Arizona is emblematic of this approach. It requires a petition to be signed by $15 \%$ of the total number of voters who cast votes for governor in the preceding election. At that point, the proposed amendment appears on the ballot to be decided by a majority of voters in a general election. ${ }^{226}$

In short, state constitutional amendments are surmountable in all twenty-seven Nonrecognizing States, as Figure 23 shows. In all but seven states, constitutions can be surmounted without "supermajority" votes by the legislature.

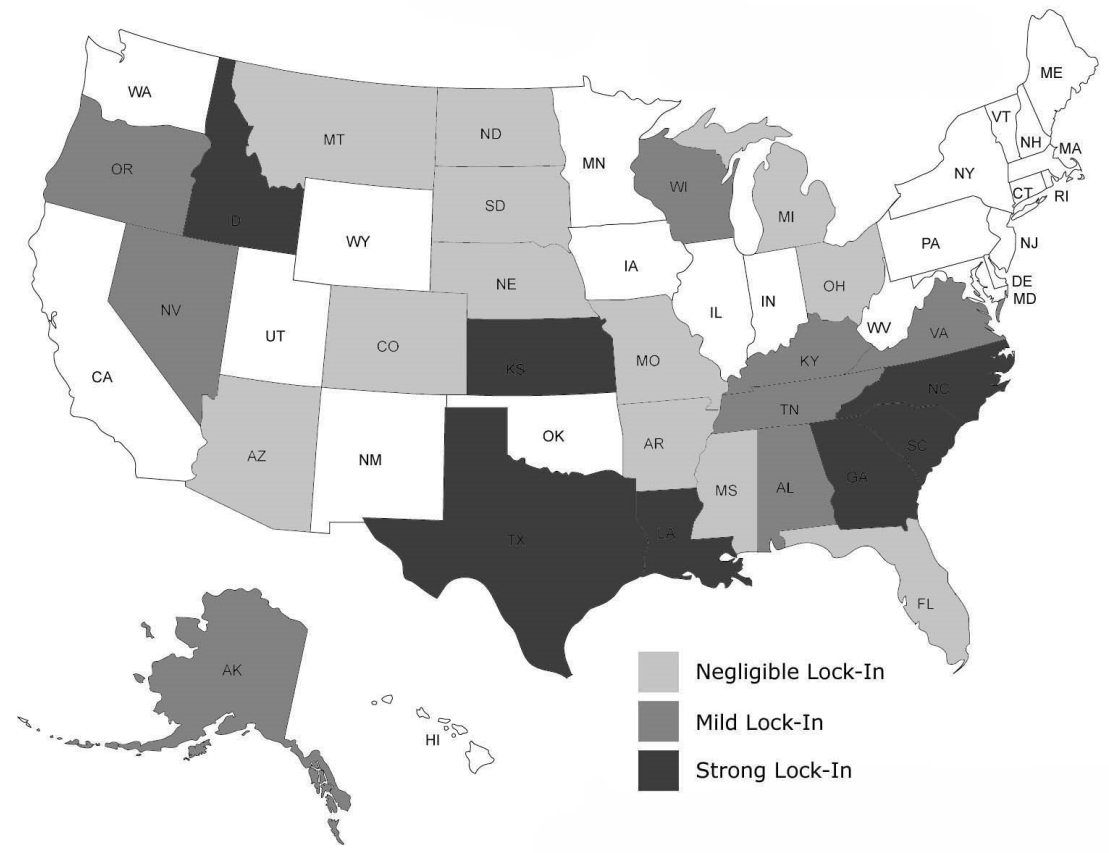

Figure 23: Lock-In Effect of Constitutional Same-Sex Marriage Ban

and then a simple majority of the electorate. Convention and Initiative Methods: the voters may amend the constitution directly by referendum by a simple majority of voters).

225. See sources cited supra note 205.

226. ArIZ. Const. art. XXI, § 1-2. Note that if Arizona only had a Legislative Method as opposed to a Legislative and a Voter Initiative method, then Arizona would have a mild lock-in effect. 
While constitutional amendments contribute to the difficult political terrain, it is clear that legislation to recognize same-sex marriage will be possible in nearly all of these states by the end of the decade, as Figure 24 shows.

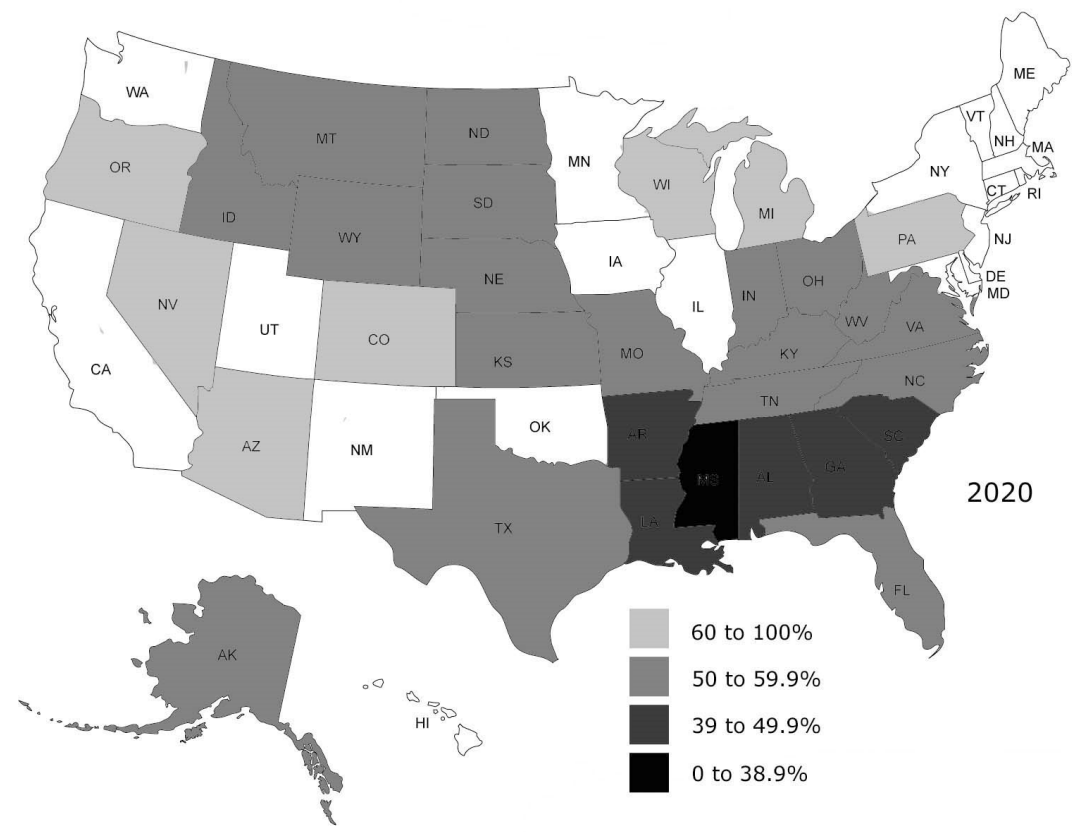

FiguRE 24: Projected Support for Same-Sex Marriage by 2020

By 2020, putting aside the lock-in effect, virtually every state is likely to have sufficient support to recognize same-sex marriage. Only six states show support below 50\% and all but two are within a few percentage points of a majority. Average support for same-sex marriage will crest $55.8 \%$ across the Nonrecognizing States. Mississippi brings up the bottom with support at $37.8 \%$, while at the top end, support in Oregon will hit 65.4\%. 2020 may seem a long way away, but constitutional bans are fragile today, at least in the negligible and mild lock-in states.

Because so many state constitutional bans can be undone with a fraction of the population's signatures and majority support, it is important to stay focused on the tide of popular support. Figure 25 shows actual support in 1994-96, actual support at the time of the constitutional amendment, and actual support in 2008, as well as projected support for 2012 and 2016. ${ }^{227}$ It shows that of the states

227. The 1994-96 and 2010 support data are taken from the New York Times. Andrew Gelman, Jeffrey Lax \& Justin Phillips, Over Time, a Gay Marriage Groundswell, N.Y. Times, Aug. 22, 2010, at WK3. ("In all of the time periods shown here, a statistical technique has been used to generate state estimates from national polls. Public opinion is 
with negligible lock-ins, by 2012, a majority of the population in ten of the twelve do support same-sex marriage or are within striking distance of majority support (Arizona, Colorado, Florida, Missouri, Montana, Michigan, Nebraska, Ohio, North Dakota, and South Dakota). ${ }^{228}$ By 2016, only four of the negligible lock-in effect states would not have majority support for same-sex marriage (Arkansas, Mississippi, Missouri, and South Dakota). ${ }^{229}$ Because the constitutions in these states are almost as easy to amend as enacting ordinary legislation, the need to bargain now is at its greatest.

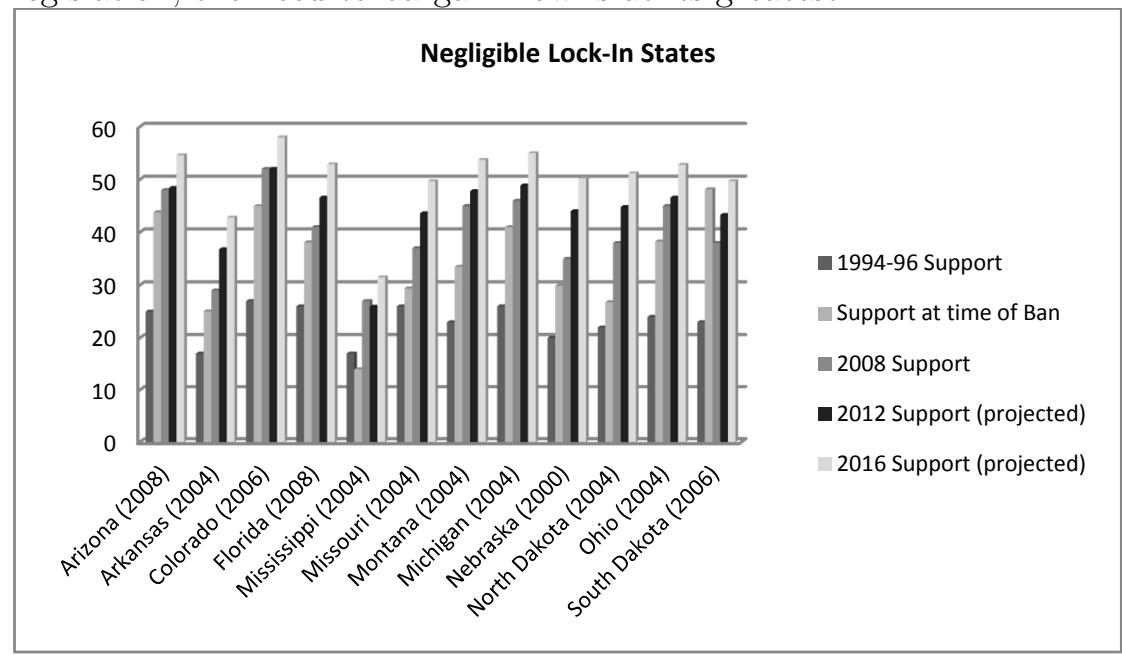

Figure 25: Projected Support in Negligible Lock-In States

Figure 26 further illustrates the flimsiness of state constitutional amendments. Of the eight mild lock-in states, a majority of the populations in three states (Nevada, Oregon, and Wisconsin) already supported same-sex marriage by 2012, putting those bans at risk today. ${ }^{230}$ By 2016, in more than half of the states, five of the eight, a majority of the population will support same-sex marriage (Alaska, Nevada, Oregon, Virginia, and Wisconsin). ${ }^{231}$

estimated in small demographic categories within each state, and then these are averaged using census information to get state-level summaries. Estimates in 2010 are projected from 2008 state-level estimates using an aggregate national estimate of forty-five percent (or fifty percent) support for gay marriage."). The 2012 and 2016 statistics are taken from Silver, supra note 125. Table A6 gives actual support at the time of the amendment at the ballot box by subtracting opposition support from one hundred.

228. See infra Table A6.

229. Id.

230. Id.

231. Id. 


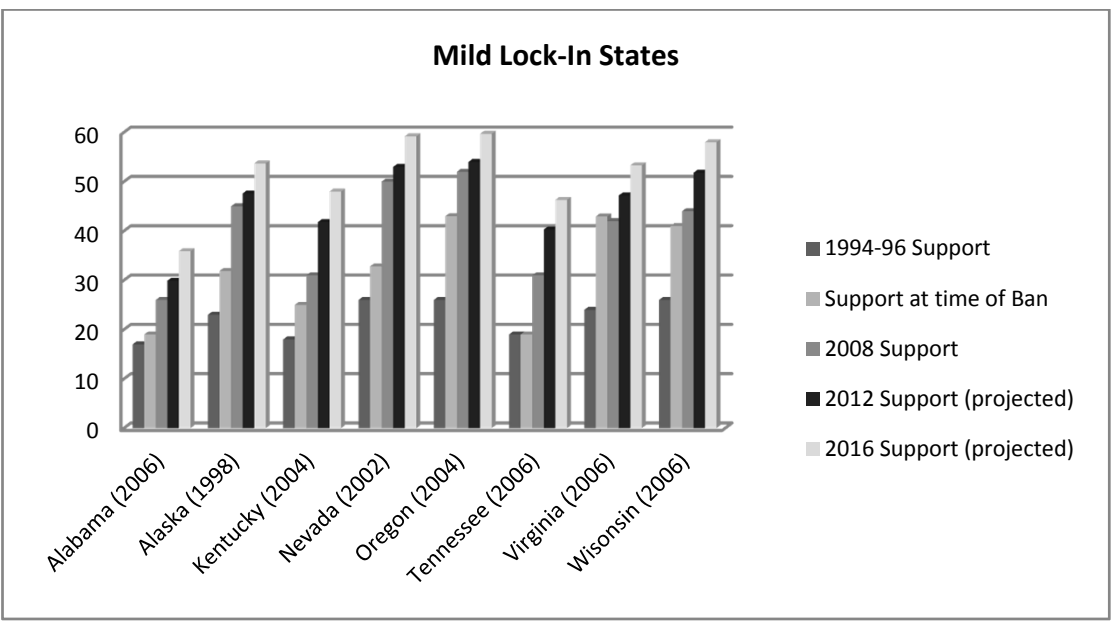

Figure 26: Projected Support in Mild Lock-In States

Figure 27 does paint a different picture. The strong lock-in effect states generally show low support for same-sex marriage. The seven strong lock-in states are not likely to enact same-sex marriage in the near future, based either on public support or the strength of the constitutional amendment. ${ }^{232}$

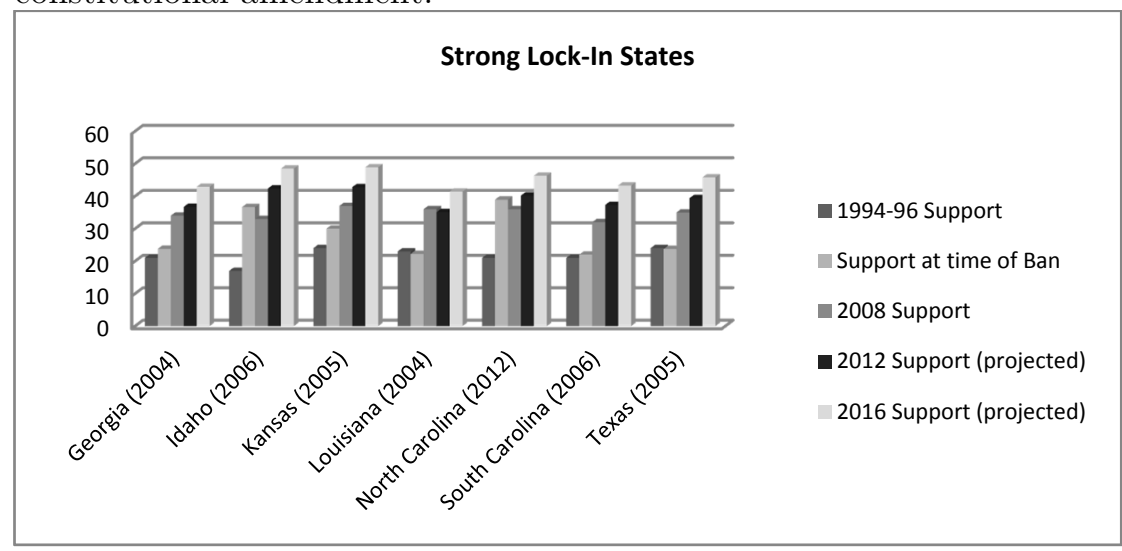

FiguRE 27: Projected Support in Strong Lock-In States

In only those states where projected support likely will remain well below $50 \%$ by 2020 (Mississippi and Alabama) and those strong lock-in states (Georgia, Idaho, Kansas, Louisiana, North Carolina, South Carolina, and Texas) are opponents reasonably assured of being able to push back same-sex marriage if the question is left to the political process. While no one can predict with confidence what the 
future holds, ${ }^{233}$ how one bargains today is often influenced by how one perceives the future and the bargain one believes one can strike tomorrow or beyond.

Even with the difficult terrain, in the long term, advocates are likely to secure same-sex marriage in the political process when popular support eventually overpowers all other characteristics. For same-sex marriage opponents who may be tempted to rely on the more difficult terrain facing advocates, ${ }^{234}$ Utah and Oklahoma are illustrative.

233. The political terrain of any state may change overnight. In 2013, samesex couples filed suit challenging Virginia's same-sex marriage ban on federal constitutional grounds. See Bostic v. Rainey, No. 2:13-cv-395, 2014 WL 561978, (E.D. Va. Feb. 13, 2014); see also Harris v. McDonnell, No. 5:13-cv-00077, 2013 WL 5720355, (W.D. Va. Oct. 18, 2013) (a class action lawsuit). Then-Attorney General Ken Cuccinelli defended the suits. See Robert Barnes, Virginia to Fight Gay Marriage Ban, The Washington Post (Jan 23. 2014). On the heels of the November 2013 election, Virginia's new Attorney General Mark Herring will not defend Virginia's constitutional ban, saying that he believes it is unconstitutional. In the vacuum created by General Herring's decision, it is unclear who, if anyone, has standing to defend the law. For a discussion of the unique issues of standing in ballot initiatives, see Vikram D. Amar, Should Initiative Proponents Be Permitted Under Article III to Defend in Federal Court?, 48 UC DAvis L. REv. (forthcoming Dec. 2014); Vikram Amar, Revisiting Standing: Proposition 8 in the Ninth Circuit, JURIST (Feb. 16, 2012), http://jurist.org/forum/2012/02/vikram-amar-marriage-standing.php.

Virginia House Bill 706 seeks, after the fact, to provide the ability for any legislator to defend the laws of the Commonwealth. See H.B. 706, 2014 Session (Va. 2014). Even though the dynamics of any one state may quickly change in important ways, some of the characteristics favoring marriage equality are more stable than others, like educational attainment and religiosity. Moreover, while characteristics may see-saw in an individual state, the broad pattern in the 31 Nonrecognizing States is likely to remain consistent.

234. In this legislative cycle, stand-alone legislation "concerning religious freedoms with respect to marriage" has been introduced in states that are not anticipated to recognize same-sex marriage any time soon, like Kansas. See H.B 2453, Session of 2014 (Kan. 2014). This Article contends that the strongest religious liberty protections will result from trading protections for marriage equality. It is possible that staggering the two goods - religious freedom protections and the recognition of marriage equality - so that they happen at different points in time, may also result in strong protections. It is hard to know whether locking in protections in advance of marriage equality would grease the way for enabling marriage equality legislation or make it more difficult.

Advocates of a staggered approach say that when enabling legislation does arise, opponents cannot then say that marriage equality will hurt religious freedom. Thus, opponents of same-sex marriage forfeit a powerful political weapon against same-sex marriage in exchange for locking in religious liberty protections. 
Judicial decisions in Utah and Oklahoma underline what is at stake. Oklahoma and Utah shared a number of characteristics suggesting that both would have been among the last states to adopt same-sex marriage by legislation. Party representation, religiosity, education, lack of statewide sexual orientation protections, the presence of a constitutional amendment against same-sex marriage, and low support for same-sex marriage all played to the opposition.

A majority of people in Utah is not projected to support same-sex marriage until 2020. In 2016, Silver estimates $48.1 \%$ would support same-sex marriage. Utah's Republican-controlled legislature and Republican Governor, its status as the second most religious state in the nation behind only Mississippi, its lack of a statewide sexual orientation nondiscrimination law, and strongly locked-in constitutional amendment all would make the reasonable observer believe that Utah would not legislatively adopt same-sex marriage any time soon. Only its relatively educated populace, just outside of the top one-third and nineteenth overall for the United States, would suggest otherwise.

Oklahoma is not much different. Projected support in Oklahoma barely breaks a majority in 2020 , with only $51.5 \%$ projected to favor same-sex marriage - up from a projected $44.7 \%$ in 2016. Oklahoma's Republican legislature, Republican Governor, high religiosity (top one-third), low education levels (bottom one-third), and lack of

If enacted, these protections would appear in stand-alone legislation that presumably will be revisited when, and if, the state embraces marriage equality. This approach cleanly makes religious freedom arguments on their own merits, as opposed to making them during a pitched battle over same-sex marriage recognition. When religious freedom is raised in the context of a pitched battle, some advocates, members of the public, and legislators may suspect the religious freedom arguments are nothing more than an obstructionist tactic designed to defeat same-sex marriage on the merits.

In states that lack a sexual orientation nondiscrimination ban in statewide law, it is unclear what legal risk objectors are being immunized against. See Figure 20. As important, unlike the model protections that I and others propose, these proposals have not contained important constraints on the size of organizations that could claim an exemption, nor do they take into consideration any hardship to same-sex couples. See supra note 88 (providing information about model religious liberty protections). Standalone legislation in states that do not give protections to LGBT individuals also smack of a one-sided deal because it would protect only religious objectors while giving nothing tangible to the LGBT community.

A better way forward for this kind of legislation would be to protect or enlarge the rights of both sides in the same piece of legislation-for example, by giving LGBT people a much-needed promise of nondiscrimination in society, recognition of relationships, or access to marriage. 
statewide sexual orientation protections suggest Oklahoma would have been a very late adopter. Oklahoma's negligible lock-in effect for its constitutional ban would have mattered little in light of very low support for same-sex marriage. Utah and Oklahoma illustrate the risks of delay for religious liberty advocates. What should legislators in Utah and Oklahoma (and elsewhere) do now? Where federal district court decisions require that same-sex marriage be recognized, legislators who otherwise may not be inclined to grant marriage equality by statute should act to do so, locking in religious liberty protections pending the appeal.

With all the attention paid to judicial decisions in Utah and Oklahoma, it is easy to forget that a number of constitutional amendment states are in play. A ballot initiative underway now in Ohio seeks to overturn Ohio's 2004 Constitutional Amendment. In Ohio, a mild lock-in effect state, public opposition to same-sex marriage has dropped precipitously since the Amendment's passage in 2004, falling to a mere $37 \%$ from $62 \% .{ }^{235}$ The proposed Amendment in Ohio would mandate marriage equality without any religious liberty protections. $^{236} \mathrm{~A}$ similar movement is underway in Oregon where voters have "collected enough signatures to give voters a chance to legalize same-sex marriage in 2014."237 The Oregon measure, like Maine's, would provide modest religious liberty protections for organizations.

Some may think that because the U.S. Supreme Court is likely to decide the entitlement to same-sex marriage by 2015, it is pointless to bargain now. Proponents may believe that it would be better to wait out the next state legislative round, hoping for a victory in the Supreme Court. Yet, there is no assurance that the Supreme Court will wade in on this question in the near term, especially in the absence of a circuit split. ${ }^{238}$ Moreover, a decision favoring marriage equality is not assured, even if increasingly likely. Thus, bargaining for marriage equality supporters delivers a concrete gain now for real families clamoring to marry.

235. Sandhya Somashekhar \& Peyton M. Craighill, Polls in 3 States See Gay-Union Support, WAsh. Post, October 10, 2012, at A8; see Table A6.

236. Anna Staver, Same-Sex Marriage Amendment In Ohio Gets Green Light, Huffington Post (April 3, 2012, 6:44 PM), http://www. huffingtonpost.com/2012/04/03/same-sex-marriage-amendment-ohio_n 1400714.html.

237. KATU News, Oregon same-sex marriage advocates celebrate ballot measure milestone, KATU.com (Dec. 9, 2013, 12:28 PM) http://www.katu.com/politics/Oregon-same-sex-marriage-advocatescelebrate-ballot-measure-milestone-235105391.html.

238. See supra note 59 . 
Even if the Court holds that marriage equality is constitutionally demanded, red states could still enact religious liberty protections at that point simply based on the state's demographics. Ironically, the chances of enacting religious liberty protections on the heels of a Supreme Court decision may be greater in 2016 than if the Court's decision comes later. ${ }^{239}$

Others may believe that a victory in the Supreme Court at any time will sideline every motivation for finding a "live and let live" approach to same-sex marriage. True, religious liberty advocates may not have any bargaining leverage on the marriage issue. But they may have bargaining leverage if they are willing to enact sexual orientation non-discrimination laws as part of a package to get religious liberty protections with respect to marriage. In short, even if the right to marry is assured by the Court, the bargaining may shift to sorely needed nondiscrimination protections, rather than disappearing entirely.

\section{Conclusion}

No one can say with confidence that the United States Supreme Court will not "shut down the marriage debate and impose gay marriage uniformly." ${ }^{240}$ Until that happens, there is a closing window of opportunity for healing the schism over same-sex marriage. The way forward in this very divisive debate is for both sides to be respectful of the other. ${ }^{241}$ As with many deeply divisive topics, the natural impulse often is to resist compromise, but neither side can afford to do so.

Same-sex marriage by legislation has been a decidedly blue state phenomenon, but it will not remain so. The political terrain facing the marriage equality movement going forward means that religious liberty will remain yoked to same-sex marriage recognition until public support engulfs all opposition. The decision squarely in front of marriage equality advocates is whether to lock-in same-sex marriage now, with protections for religious dissenters, or to wait, relying on overwhelming public support alone. ${ }^{242}$

239. See Table A4. Compare Figure 22 with Figure 24.

240. Dreher, supra note 38, at 12 (quoting Maggie Gallagher).

241. For a pair of views on the divisiveness debate, see Smith, supra note 63 and Laycock, supra note 218.

242. Some would contend that marriage equality advocates have an incentive not to bargain, waiting for judicial decisions that deliver same-sex marriage without exemptions specific to marriage. Because no one can be assured of when courts will act, and what outcome they will reach, refusing to bargain necessarily puts off rights that could be secured legislatively today. For this reason, marriage equality advocates would be gambling to say, "No thanks, we will wait for Justice Kennedy." 
For opponents, the more challenging political terrain also means that the best opportunity to cement meaningful religious liberty protections is now. If opponents act now, trading recognition of samesex marriage for robust protections, then opponents will have muted the impact of same-sex marriage on like-minded believers. It is true that the struggle over same-sex marriage is an existential fight for some who may not or cannot be moved by pragmatic appeals, but for those who can, if they resist the "damage control" within their means, ${ }^{243}$ they will only have themselves to blame. ${ }^{244}$

243. "There is not yet a unified sense of where we go from here, except for this: there is an accelerating awareness that the consequence of marriage equality is going to be extremely negative for traditionalist Christians." See Dreher, supra note 40 (quoting Maggie Gallagher).

244. For those for whom the struggle over same-sex marriage is an existential fight, pragmatic appeals may find little reception. See Smith, supra note 63 (arguing that both sides are acting on legitimate concerns and are not merely being intransigent-instead, the "contending parties understand that there is a struggle over who will be doing the accommodating to whom. Proponents of same-sex marriage perceive, correctly, that domestic partnership is not likely to have all of the same legal features and advantages as marriages; and even if it does, in such an arrangement, heterosexual marriage is the 'normal' position, and it is the same-sex couples who are being accommodated. By the same token, more traditional citizens perceive that a law recognizing same-sex marriage, even if it comes with religious freedom 'exceptions' or 'exemptions,' reverses these positions: now they are the ones who are the outliers to be accommodated."). For anyone who may be swayed by pragmatic arguments, a clear-eyed view of the benefits of compromise is important. In the end, compromise offers the best hope for closing the schism over same-sex marriage. 
Case Western Reserve LaW Review · Volume $64 \cdot$ Issue $3 \cdot 2014$ Marriage of Necessity

\section{APPENDIX}

Table A1: States Recognizing Same-Sex Marriage and the Methods by Which Same-Sex Marriage Is Recognized as of Jan. 14, $2014{ }^{245}$

\begin{tabular}{|c|c|c|c|c|c|c|c|c|c|}
\hline 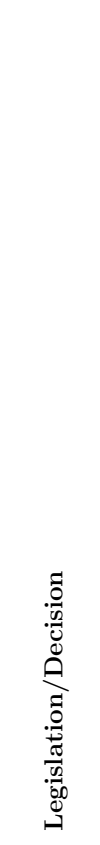 & 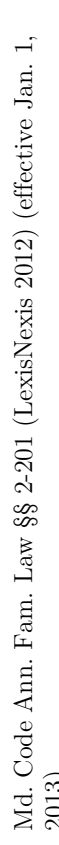 & 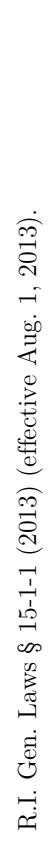 & 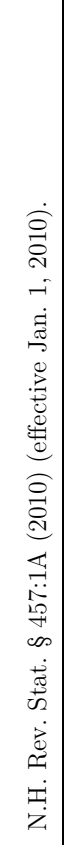 & 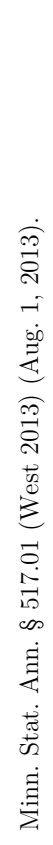 & 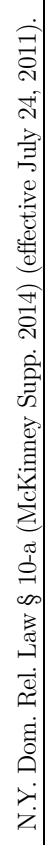 & 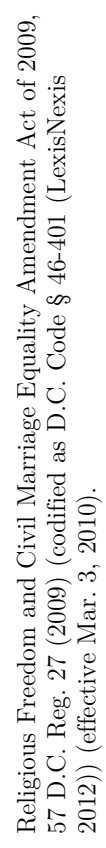 & 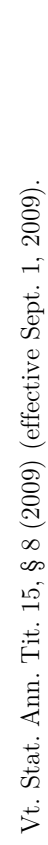 & 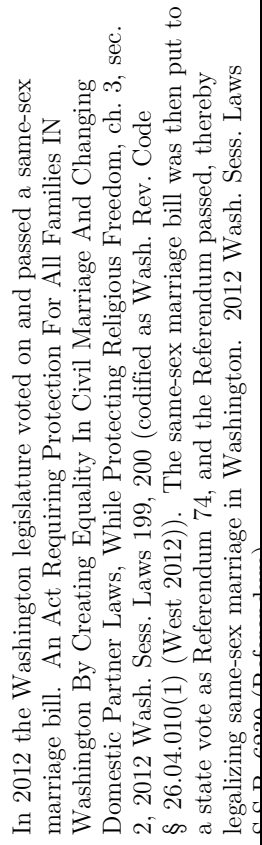 & 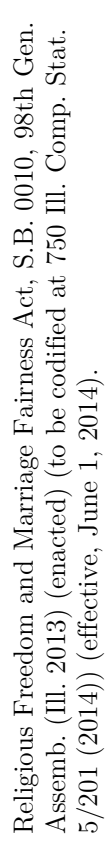 \\
\hline 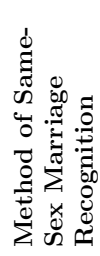 & 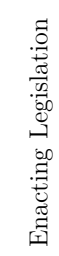 & 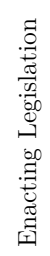 & 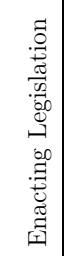 & 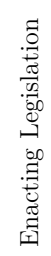 & 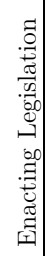 & 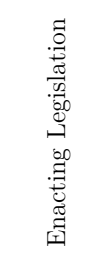 & 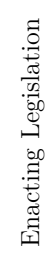 & 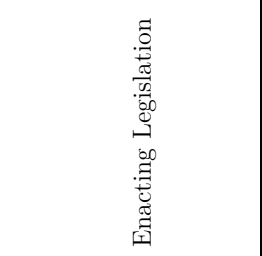 & 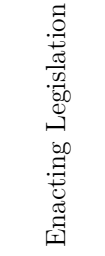 \\
\hline 营 & 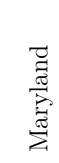 & 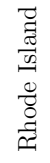 & 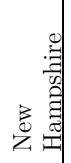 & 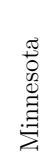 & 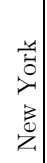 & 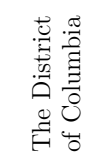 & 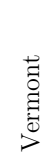 & 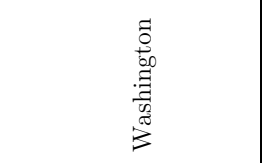 & 当 \\
\hline
\end{tabular}

245. Because the political landscape of same-sex marriage is in constant flux, it is worth noting that this Article accounts same-sex marriage laws as of January 14, 2014. During the editing cycle, a spate of same-sex marriage decisions continued to emerge from federal district courts. As just one example, Michigan's ban on same-sex marriage (the Michigan Marriage Amendment, Mich. Const. art. I, § 25) has been held unconstitutional. See Deboer v. Snyder, No. 12-CV-10285, 2014 WL 1100794 (E.D. Mich. Mar. 21, 2014). However, the United States Court of Appeals for the Sixth Circuit has granted the state's request to stay the judgment of the district court until the appeals court has ruled on the appeal. See Deboer v. Snyder, No. 14-1341 (6th Cir. Mar. 25, 2014). 
Case Western Reserve LaW Review · Volume 64 · Issue $3 \cdot 2014$ Marriage of Necessity

Table A1 (continued): States Recognizing Same-Sex Marriage and the Methods by Which Same-Sex Marriage Is Recognized as of Jan. 14, 2014

\begin{tabular}{|c|c|c|c|c|}
\hline 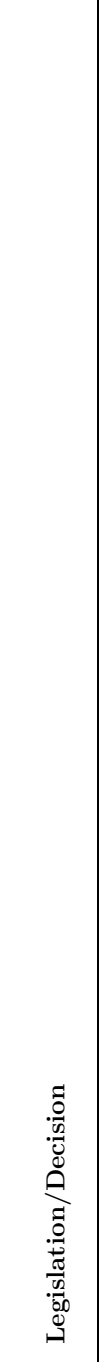 & 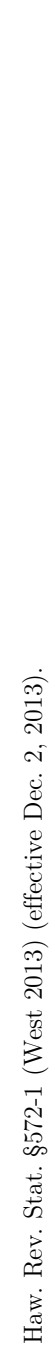 & 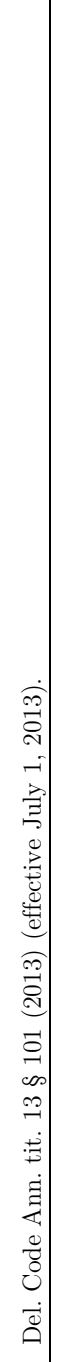 & 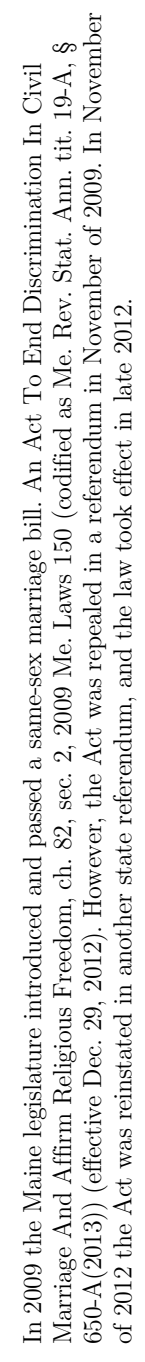 & 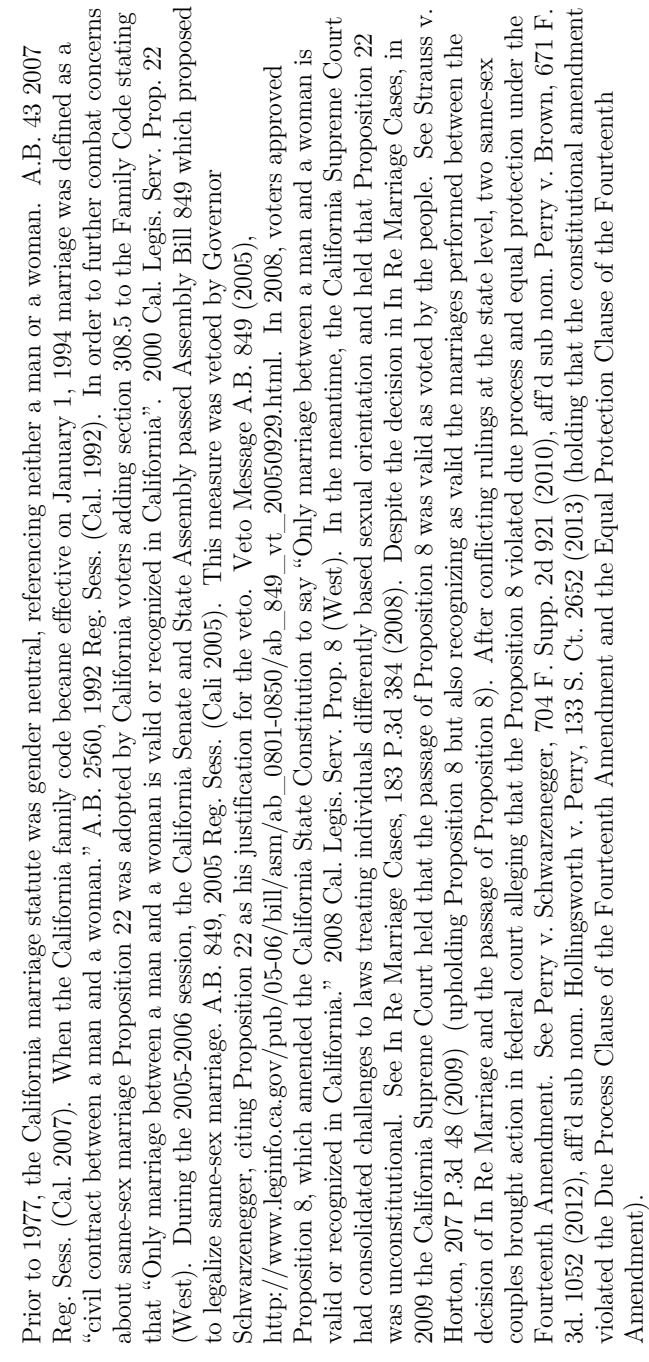 \\
\hline 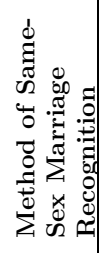 & 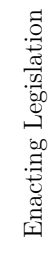 & 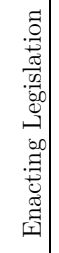 & 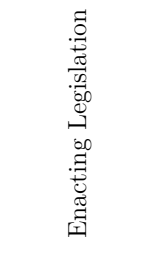 & 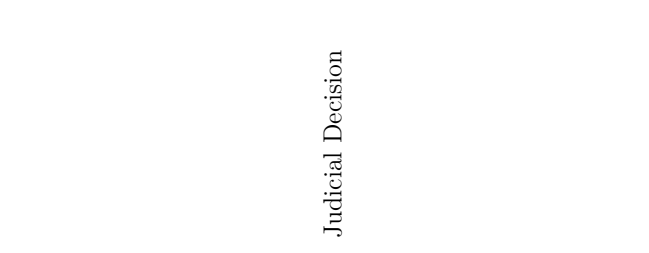 \\
\hline$\underset{\pi}{\pi}$ & 总 & 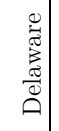 & $\stackrel{\pi}{\Sigma}^{2}$ & 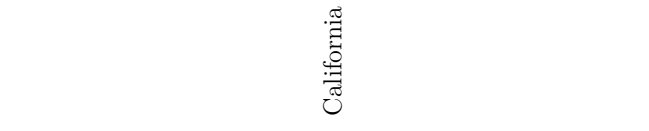 \\
\hline
\end{tabular}


Case Western Reserve Law Review · Volume 64 - Issue $3 \cdot 2014$ Marriage of Necessity

Table A1 (continued): States Recognizing Same-Sex Marriage and the Methods by Which Same-Sex Marriage Is Recognized as of Jan. 14, 2014

\begin{tabular}{|c|c|c|c|c|c|c|c|}
\hline 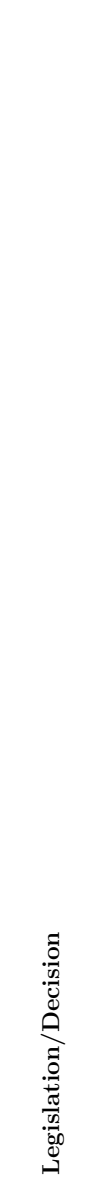 & 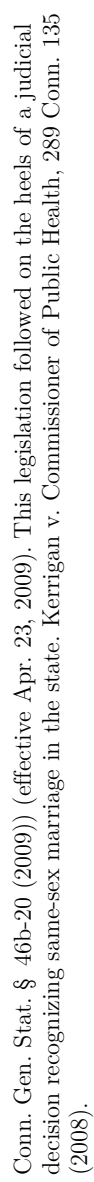 & 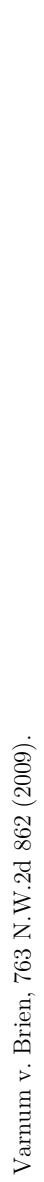 & 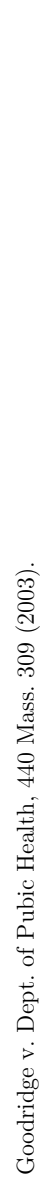 & 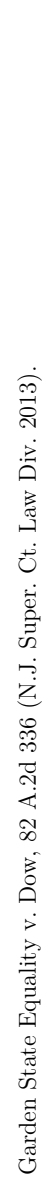 & 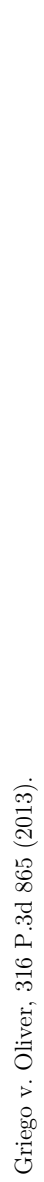 & 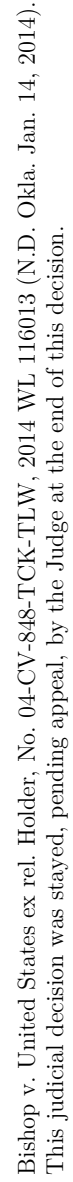 & 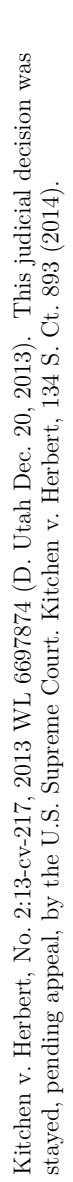 \\
\hline 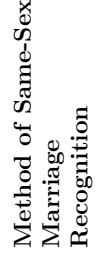 & 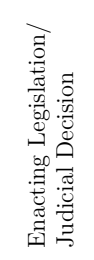 & 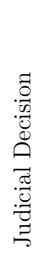 & 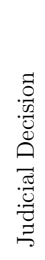 & 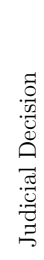 & 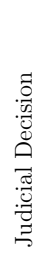 & 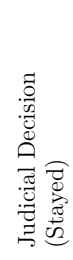 & 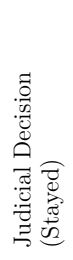 \\
\hline $\begin{array}{l}\text { D. } \\
\text { in }\end{array}$ & 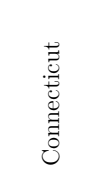 & 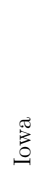 & 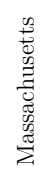 & 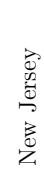 & 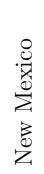 & $\begin{array}{l}\frac{\bar{d}}{\bar{m}} \\
\frac{\bar{d}}{0}\end{array}$ & 吾 \\
\hline
\end{tabular}


Case Western Reserve Law Review · Volume $64 \cdot$ Issue $3 \cdot 2014$ Marriage of Necessity

Table A2: State-Wide Sexual Orientation Nondiscrimination Measures

\begin{tabular}{|c|c|c|c|c|c|c|}
\hline & $\begin{array}{l}\text { Same-Sex } \\
\text { Marriage } \\
\text { (SSM) } \\
\text { Legislation }\end{array}$ & $\begin{array}{c}\text { Employment } \\
\text { Discrimination }\end{array}$ & $\begin{array}{c}\text { Housing } \\
\text { Discrimination }\end{array}$ & $\begin{array}{c}\text { Public } \\
\text { Accommodations }\end{array}$ & $\begin{array}{c}\text { Other } \\
\text { Nondiscrimination } \\
\text { Measures }\end{array}$ & $\begin{array}{c}\text { Years } \\
\text { Other } \\
\text { Protections } \\
\text { Preceded } \\
\text { SSM } \\
\text { Legislation } \\
246\end{array}$ \\
\hline \multicolumn{7}{|c|}{ Enacting Jurisdictions } \\
\hline $\mathrm{CT}$ & $2009^{247}$ & $1991^{248}$ & $1991^{249}$ & $1991^{250}$ & $\begin{array}{c}1991^{251} \\
\text { (Education) } \\
2011^{252} \text { (Credit) }\end{array}$ & 18 years \\
\hline $\mathrm{DE}$ & $2013^{253}$ & $2009^{254}$ & $2009^{255}$ & $2009^{256}$ & & 4 years \\
\hline $\mathrm{DC}$ & $2009^{257}$ & $1977^{258}$ & $1977^{259}$ & $1977^{260}$ & $\begin{array}{c}1977^{261} \\
\text { (Education) }\end{array}$ & 32 years \\
\hline $\mathrm{HI}$ & $2013^{262}$ & $1991^{263}$ & $2005^{264}$ & $2006^{265}$ & & 22 years \\
\hline IL & $2013^{266}$ & $2004^{267}$ & $2004^{268}$ & $2004^{269}$ & $2004^{270}$ (Credit) & 9 years \\
\hline $\mathrm{MD}$ & $2012^{271}$ & $2009^{272}$ & $2009^{273}$ & $2009^{274}$ & $\begin{array}{c}2008^{275} \\
\text { (Education) }\end{array}$ & 4 years \\
\hline $\mathrm{MN}$ & $2013^{276}$ & $1993^{277}$ & $1993^{278}$ & $1993^{279}$ & $1993^{280}$ (Credit) & 20 years \\
\hline $\mathrm{NH}$ & $2009^{281}$ & $1997^{282}$ & $1997^{283}$ & $1997^{284}$ & & 12 years \\
\hline NY & $2011^{285}$ & $2002^{286}$ & $2002^{287}$ & $2002^{288}$ & \begin{tabular}{|c|}
$2002^{289}$ \\
(Education, \\
Credit, and Other \\
Various \\
Protections) \\
\end{tabular} & 9 years \\
\hline $\mathrm{RI}$ & $2013^{290}$ & $1995^{291}$ & $1995^{292}$ & $1995^{293}$ & $\begin{array}{c}1995^{294} \\
\text { (Education) }\end{array}$ & 18 years \\
\hline VT & $2009^{295}$ & $1992^{296}$ & $1992^{297}$ & $1992^{298}$ & $2000^{299}$ (Credit) & 17 years \\
\hline WA & $2012^{300}$ & $2006^{301}$ & $2006^{302}$ & $2006^{303}$ & $\begin{array}{c}2006^{304} \text { (Education } \\
\text { and Credit) }\end{array}$ & 6 years \\
\hline \multicolumn{7}{|c|}{ Nonrecognizing Jurisdictions with Antidiscrimination Measures } \\
\hline $\mathrm{CO}$ & $\mathrm{N} / \mathrm{A}$ & 305 & 306 & 307 & 308 & $\mathrm{~N} / \mathrm{A}$ \\
\hline NV & $\mathrm{N} / \mathrm{A}$ & 309 & 310 & 311 & $\mathrm{~N} / \mathrm{A}$ & $\mathrm{N} / \mathrm{A}$ \\
\hline OR & $\mathrm{N} / \mathrm{A}$ & 312 & 313 & 314 & 315 & $\mathrm{~N} / \mathrm{A}$ \\
\hline WI & $\mathrm{N} / \mathrm{A}$ & 316 & 317 & 318 & 319 & $\mathrm{~N} / \mathrm{A}$ \\
\hline
\end{tabular}

246. This column is only relevant for the enacting jurisdictions. It is measured by the time which passed between the enactment of the earliest nondiscrimination measure protecting against sexual orientation discrimination and the enactment of same-sex marriage legislation.

247. An Act Implementing The Guarantee Of Equal Protection Under The Constitution Of The State For Same Sex Couples, Pub. Acts No. 09-13, sec. 3, 2009 Conn. Acts 78, 79 (Reg. Sess.) (codified as Conn. Gen. STAT. § 46b-20 (2009)).

248. An Act Concerning Discrimination On The Basis Of Sexual Orientation, Pub. Acts No. 91-58, sec. 3, 1991 Conn. Acts 118, 119 (codified as Conn. Gen. Stat. § 46a-60 (West 2009)).

249. An Act Concerning Discrimination On The Basis Of Sexual Orientation, Pub. Acts No. 91-58, sec. 5, 1991 Conn. Acts 118, 119-120; An Act Concerning Discriminatory Housing Practices, Pub. Acts No. 92-257, 
sec. 2, 1992 Conn. Acts 839, 840-841 (codified as Conn. Gen. Stat. § 46a-64c (West 2009)).

250. An Act Concerning Discrimination On The Basis Of Sexual Orientation, Pub. Acts No. 91-58, sec. 4, 1991 Conn. Acts 118, 119 (codified as Conn. Gen. Stat. § 46a-64 (West 2009)).

251. An Act Concerning Discrimination On The Basis Of Sexual Orientation, Pub. Acts No. 91-58, sec. 10, 1991 Conn. Acts 118, 121 (codified as Conn. Gen. Stat. § 46a-75 (West 2009)).

252. An Act Concerning Discrimination On The Basis Of Sexual Orientation, Pub. Acts No. 91-58, sec. 6, 1991 Conn. Acts 118, 120 (codified as Conn. Gen. Stat. § 46a-66 (West 2009)).

253. An Act To Amend Title 13 of the Delaware Code Relating to Domestic Relations to Provide for Same-Gender Civil Marriage and to Convert Civil Unions to Civil Marriages, H.B. 75, 147th Gen. Assemb. (Del. 2013) (enacted) (codified as DEL. CodE AnN. TIT. $13 \S 101$ (2013) (effective July 1, 2013).

254. An Act To Amend Titles 6, 9, 18, 19, 25, And 29 Of The Delaware Code Relating To Discrimination In Employment, Public Works Contracting, Housing, Equal Accommodations And The Insurance Business, ch. 90, secs. 17-19, 77 Del. Laws 264, 265 (2009) (codified as Del. Code Ann. Tit. 19, § 711 (West 2013)).

255. An Act To Amend Titles 6, 9, 18, 19, 25, And 29 Of The Delaware Code Relating To Discrimination In Employment, Public Works Contracting, Housing, Equal Accommodations And The Insurance Business, ch. 90, sec. 7, 77 Del. Laws 264, 265 (2009) (codified as DeL. Code Ann. Tit. 6, § 4603 (West 2013).

256. An Act To Amend Titles 6, 9, 18, 19, 25, And 29 Of The Delaware Code Relating To Discrimination In Employment, Public Works Contracting, Housing, Equal Accommodations And The Insurance Business, ch. 90, sec. 4, 77 Del. Laws 264 (2009) (codified as Del. Code ANN. TIT. 6, § 4604 (West 2013).

257. Religious Freedom and Civil Marriage Equality Amendment Act of 2009, 57 D.C. Reg 27 (Mar. 10, 2010) (codified as D.C. Code $§ 46-401$ ).

258. Human Rights Act of 1977, D.C. Law 2-38, title II, 24 D.C. Reg. 6038 (Dec. 13, 1977) (codified as D.C. CoDE § 2-1402.11 (LexisNexis 2012)).

259. Human Rights Act of 1977, D.C. Law 2-38, title II, 24 D.C. Reg. 6038 (Dec. 13, 1977) (codified as D.C. CodE § 32-408 (LexisNexis 2012)).

260. Human Rights Act of 1977, D.C. Law 2-38, title II, 24 D.C. Reg. 6038 (Dec. 13, 1977) (codified as D.C. Code § 2-1402.21 (LexisNexis 2012)).

261. Human Rights Act of 1977, D.C. Law 2-38, title II, 24 D.C. Reg. 6038 (Dec. 13, 1977) (codified as D.C. CodE § 2-1402.41 (LexisNexis 2012)).

262. Hawaii Marriage Equality Act of 2013, sec. 3, Hawaii S.B. No. 1 (2013) (codified as HAw. Rev. Stat. § 572-1 (West 2013)) (effective Dec. 2, 2013).

263. A Bill For An Act Relating To Employment, Act 2, sec. 3, 1991 Haw. Sess. Laws 3, 4-5 (codified as Haw. Rev. Stat. § 378-2 (West 1991)). 
264. A Bill For An Act Relating To Civil Rights, Act 214, sec. 32005 Haw. Sess. Laws 688, 689-690 (codified as HaW. Rev. Stat. § 515-3 (West Supp. 2012)).

265. A Bill For An Act Relating To Civil Rights, Act 76, sec. 3, 2006 Haw. Sess. Laws 214, 215 (codified as Haw. Rev. Stat. § 489-3 (West Supp. 2012)).

266. Religious Freedom and Marriage Fairness Act, S.B. 0010, 98th Gen. Assemb. (Ill. 2013) (enacted) (to be codified at 750 Ill. Comp. Stat. 5/201 (2014)) (effective, June 1, 2014).

267. An Act Concerning Human Rights, Pub. Act No. 93-1078, art. 1, 2004 Ill. Laws 4837, 4838 (codified as 775 Ill. Comp. Stat. 5/102(A) (West 2011)).

268. An Act Concerning Human Rights, Pub. Act No. 93-1078, art. 1, 2004 Ill. Laws 4837, 4838 (codified as 775 Ill. Comp. Stat. 5/102(A) (West 2011)).

269. An Act Concerning Human Rights, Pub. Act No. 93-1078, art. 1, 2004 Ill. Laws 4837, 4838 (codified as 775 Ill. Comp. Stat. 5/102(A) (West 2011)).

270. An Act Concerning Human Rights, Pub. Act No. 93-1078, art. 1, 2004 Ill. Laws 4837, 4838 (codified as 775 Ill. Comp. Stat. 5/102(A) (West 2011)).

271. Civil Marriage Protection Act, ch. 2, sec. 12012 Md. Laws 9, 10 (codified as MD. Code Ann., FAm. LAW §§2-201 (LexisNexis 2012)) (effective Jan. 1, 2013).

272. House Bill 51, ch. 120, sec. 62009 Md. Laws 540, 567-570 (codified as Md. Code Ann., State Gov't § 20-606 (LexisNexis Supp. 2013).

273. House Bill 51, ch. 120, sec. 7, 2009 Md. Laws 540, 581-583 (codified as Md. Code Ann., State Gov't § 20-705 (LexisNexis Supp. 2013).

274. House Bill 51, ch. 120, sec. 32009 Md. Laws 540, 554 (codified as MD. Code Ann., State Gov't § 20-304 (LexisNexis Supp. 2013).

275. An Act Concerning Public Schools-Bullying, Harassment, An Intimidation-Policy And Disciplinary Standards, ch. 489, sec. 1, 2008 Md. Laws 4050, 4051-4054 (codified as Md. Code Ann., Educ. § 7424.1 (LexisNexis 2008)).

276. An Act Relating to Marriage, ch. 74, sec. 2, 2013 Minn. Laws 404, 405 (codified as Minn. Stat. Ann. § 517.01 (West 2013)) (Aug. 1, 2013).

277. An Act Relating to Human Rights: Prohibiting Unfair Discriminatory Practices On The Basis Of Sexual Orientation, ch. 22, sec. 3, 1993 Minn. Laws 121, 122-124 (codified as Minn. Stat. Ann. $§ 363.08$ SubD. 2 (West 2012)).

278. An Act Relating to Human Rights: Prohibiting Unfair Discriminatory Practices On The Basis Of Sexual Orientation, ch. 22, sec. 4, 1993 Minn. Laws 121, 124-125 (codified as Minn. Stat. AnN. § 363.09 (West 2012)).

279. An Act Relating to Human Rights: Prohibiting Unfair Discriminatory Practices On The Basis Of Sexual Orientation, ch. 22, sec. 5, 1993 Minn. Laws 121, 125-126 (codified as Minn. Stat. Ann. § 363A.11, SUbD. 1 (West 2012)). 
280. An Act Relating to Human Rights: Prohibiting Unfair Discriminatory Practices On The Basis Of Sexual Orientation, ch. 22, sec. 12, 1993 Minn. Laws 121, 138-139 (codified as Minn. Stat. Ann. § 363A.16 (West 2012)).

281. An Act Relative to Civil Marriage and Civil Unions, ch. 59, 2009 N.H. Laws 60, 60 (codified as N.H. REv. StAT. § 457:1A (2010)).

282. An Act Amending The Law Against Discrimination To Prohibit Discrimination On Account Of A Person's Sexual Orientation, ch. 108, 1997 H.H. Laws 88, 91 (codified as N.H. Rev. StAt. § 354-A:6 (2009)).

283. An Act Amending The Law Against Discrimination To Prohibit Discrimination On Account Of A Person's Sexual Orientation, ch. 108, 1997 H.H. Laws 88, 92 (codified as N.H. REV. StAт. § 354-A:8 (2009)).

284. An Act Amending The Law Against Discrimination To Prohibit Discrimination On Account Of A Person's Sexual Orientation, ch. 108, 1997 H.H. Laws 88, 92 (codified as N.H. REv. STAT. § 354-A:10 (2009)).

285. Marriage Equality Act, ch. 95, 2011 N.Y. LAws 749 (codified at N.Y. DOM. REL. LAW § 10-a (McKinney Supp. 2014)).

286. Act of Dec. 17, 2002, ch. 2, secs. 2, 5-6, §§ 291, 296(1)-(1-a), 2002 N.Y. LAWS 46, 46-48 (codified as amended at N.Y. EXEC. LAW §§ 291, 296(1)-(1-a) (McKinney 2013)).

287. Secs. 2, 8-9, 11, §§ 291, 296(2-a), (3-b), (5), 2002 N.Y. LAWs at 46-51 (codified as amended at N.Y. ExEC. LAW $\S \S 291,296(2-a),(3-b)$, (5) (McKinney 2013)).

288. Secs. 2, 7, §§ 291, 296(2) 2002 N.Y. LAWs at 46, 48 (codified as amended at N.Y. ExEC. LAW §§ 291, 296(2) (McKinney 2013)).

289. Secs. 2, 10, 12-17, §§ 291, 296(4), (9)(a), (13), 296-a, 40-c, 313(1)(a), (3), 2002 N.Y. LAWS at 46, 48, 51-53 (codified as amended at N.Y. EXEC. LAW §§ 291, 296, 296-a; CIV. Rights LAW § 40-c; EDUC. § 313 (McKinney 2013)).

290. An Act Relating to Domestic Relations-Persons Eligible to Marry, ch. 13-4, 2013 R.I. Pub. Laws (codified as R.I. GEN. LAws §15-1-1 (2013))(effective Aug. 1, 2013).

291. An Act Relating To Civil Rights , ch. 32, sec. 4, 1995 R.I. Pub. Laws 83, 85-88 (codified as R.I. Gen. Laws AnN. § 28-5-7 (2003)).

292. An Act Relating To Civil Rights , ch. 32, sec. 3, 1995 R.I. Pub. Laws 83, 87-91 (codified as R.I. Gen. Laws AnN. § 34-37-4 (2013)).

293. An Act Relating To Civil Rights, ch. 32, sec. 7, 1995 R.I. Pub. Laws 83 (codified as R.I. Gen. Laws AnN. § 11-24-2 (Supp. 2013)).

294. An Act Relating To Civil Rights, ch. 32, sec. 71995 R.I. Pub. Laws 83, 107 (codified as R.I. Gen. Laws Ann. § 28-5.1-8 (Supp. 2013)).

295. An Act Relating to Civil Marriage, no. 3, 2009 Vt. Acts \& Resolves 33 (codified as Vt. Stat. AnN. Tit. 15, § 8 (2009)).

296. An Act Relating To Discrimination On The Basis Of Sexual Orientation, No. 135, 1992 Vt. Acts \& Resolves 26, 26-27 (codified as Vt. Stat. Ann. Tit. 21, § 495(a) (2009)).. 
297. An Act Relating To Discrimination On The Basis Of Sexual Orientation, No. 135, 1992 Vt. Acts \& Resolves 26, 28-30 (codified as Vt. Stat. Ann. тiт. 9, § 4503 (Supp. 2013)).

298. An Act Relating To Discrimination On The Basis Of Sexual Orientation, No. 135, 1992 Vt. Acts \& Resolves 26, 30-31 (codified as Vt. Stat. Ann. тiт. 9, § 4502(a) (Supp. 2013)).

299. An Act Relating To The Modernization Of The Laws Related To Banks And Banking, No. 153, 2000 Vt. Acts \& Resolves 509, 593 (codified as Vt. Stat. Ann. тiт. 8, § 10403 (Supp. 2013)).

300. An Act Requiring Protection For All Families In Washington By Creating Equality In Civil Marriage And Changing Domestic Partner Laws, While Protecting Religious Freedom, ch. 3, 2012 Wash. Sess. Laws 199 (codified as WAsh. Rev. Code § 26.04.010(1) (West 2012)).

301. An Act Relating To The Jurisdiction Of The Washington Human Rights Commission, ch. 4, 2006 Wash. Sess. Laws 12 (codified as WASH. REv. CODE $\S 49.60 .180$ (2012)).

302. An Act Relating To The Jurisdiction Of The Washington Human Rights Commission, ch. 4, 2006 Wash. Sess. Laws 12 (codified as WASH. REv. CODE $\S 49.60 .222$ (2012)).

303. An Act Relating To The Jurisdiction Of The Washington Human Rights Commission, ch. 4, 2006 Wash. Sess. Laws 12 (codified as WAsH. REv. CODE $\S 49.60 .215$ (2012)).

304. An Act Relating To The Jurisdiction Of The Washington Human Rights Commission, ch. 4, 2006 Wash. Sess. Laws 12 (codified as WASH. REv. CODE $\S 49.60 .040(2)(2012))$.

305. An Act Concerning The Expansion Of Employment Nondiscrimination Protections, ch. 295, 2007 Colo. Sess. Laws 1254, 1254-1256 (codified as Colo. Rev. Stat. § 24-34-402 (2013)).

306. An Act Concerning The Expansion Of Prohibitions Against Discrimination, ch. 341, 2008 Colo. Sess. Laws 1593, 1593-1595 (codified as Colo. Rev. Stat. § 24-34-502 (2013)).

307. An Act Concerning The Expansion Of Prohibitions Against Discrimination, ch. 341, 2008 Colo. Sess. Laws 1593, 1595-1596 (codified as Colo. Rev. Stat. § 24-34-601 (2013)).

308. An Act Concerning The Expansion Of Prohibitions Against Discrimination, ch. 341, 2008 Colo. Sess. Laws 1593, 1596-1597 (codified as Colo. Rev. Stat. § 12-59-106(1)(s) (2013)).

309. An Act Relating to Employment Practices, ch. 419, 1999 Nev. Stat. 1935, 1938 (codified as NEv. Rev. Stat. § 613.330 (2012)).

310. An Act Relating to Housing, ch. 191, 2011 Nev. State 867 (codified as Nev. Rev. Stat. § 118.020 (Supp. 2013)).

311. An Act Relating to Public Accommodations, ch. 195, 2009 Nev. Stat. 716, 717 (codified as Nev. Rev. Stat. § 651.070 (West Supp. 2013)).

312. An Act Relating to Sexual Orientation Discrimination, ch. 100, sec. 29, 2007 Or. Laws 431, 443 (codified as Or. Rev. Stat. § 659.850(2) (2013)). 
313. An Act Relating to Sexual Orientation Discrimination, ch. 100, sec. 4, 2007 Or. Laws 431, 432-433 (codified as Or. Rev. StAT. § 659A.030 (2013)).

314. An Act Relating to Sexual Orientation Discrimination, ch. 100, sec. 8, 2007 Or. Laws 431, 434-435 (codified as Or. Rev. Stat. § 659A.421 (2013)).

315. An Act Relating to Sexual Orientation Discrimination, ch. 100, sec. 5, 2007 Or. Laws 431, 433 (codified as Or. Rev. Stat. § 659A.403 (2013)).

316. 1981 Wisconsin Act 112, ch. 112, sec. 2, 1981 Wis. Sess. Laws 901, 902 (codified as Wis. Stat. AnN. § 111.31(2) (West Supp. 2013)).

317. 1981 Wisconsin Act 112, ch. 112, sec. 4, 1981 Wis. Sess. Laws 901, 902 (codified as Wis. Stat. Ann. § 106.50 (West Supp. 2013)).

318. 1981 Wisconsin Act 112, ch. 112, sec.3, 1981 Wis. Sess. Laws 901, 902 (codified as Wis. Stat. AnN. § 106.52 (West Supp. 2013)).

319. 1989 Wisconsin 186, ch. 186, sec. 1, 1989 Wis. Sess. Laws 1113 (codified as Wis. Stat. Ann. § 36.12 (West 2013)). 
Case Western Reserve Law Review · Volume 64 - Issue $3 \cdot 2014$ Marriage of Necessity

Table A3: Religious Liberty Protections in Same-Sex Marriage States

\begin{tabular}{|c|c|c|c|c|c|c|c|c|c|c|}
\hline & 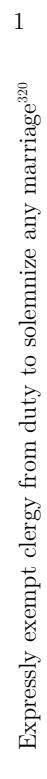 & 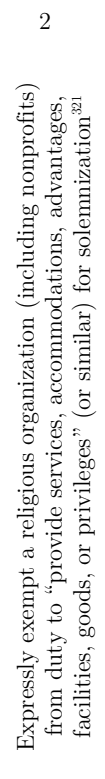 & 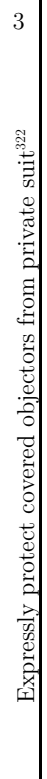 & 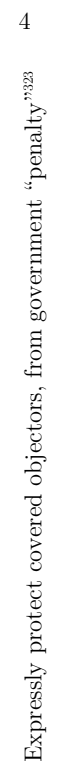 & 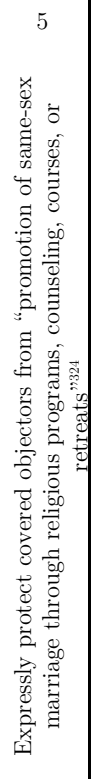 & 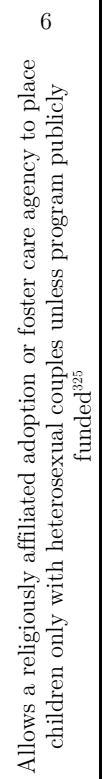 & 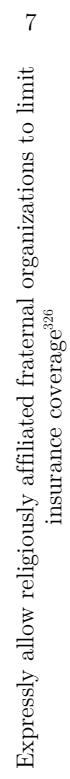 & 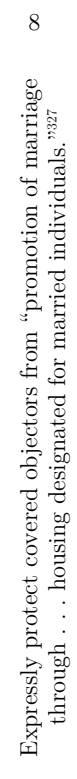 & 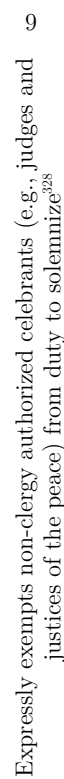 & 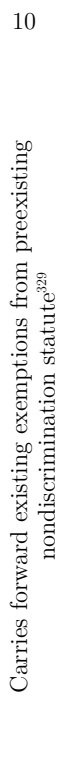 \\
\hline \multicolumn{11}{|c|}{ Same-Sex Marriage by Legislation } \\
\hline Maryland & $\checkmark$ & $\checkmark$ & $\checkmark$ & $\checkmark$ & $\checkmark$ & $\checkmark$ & $\checkmark$ & & & \\
\hline Rhode Island & $\checkmark$ & $\checkmark$ & $\checkmark$ & $\checkmark$ & $\checkmark$ & $\checkmark$ & $\checkmark$ & & & $\checkmark$ \\
\hline $\begin{array}{l}\text { New } \\
\text { Hampshire }\end{array}$ & $\checkmark$ & $\checkmark$ & $\checkmark$ & $\checkmark$ & $\checkmark$ & & $\checkmark$ & $\checkmark$ & & $\checkmark$ \\
\hline Minnesota & $\checkmark$ & $\checkmark$ & $\checkmark$ & $\checkmark$ & & $\checkmark$ & & $\checkmark$ & & $\checkmark$ \\
\hline $\begin{array}{l}\text { Connecticut } \\
330\end{array}$ & $\checkmark$ & $\checkmark$ & $\checkmark$ & $\checkmark$ & & $\checkmark$ & & & & \\
\hline D.C. & $\checkmark$ & $\checkmark$ & $\checkmark$ & $\checkmark$ & $\checkmark$ & & & & & \\
\hline New York & $\checkmark$ & $\checkmark$ & $\checkmark$ & $\checkmark$ & & & & $\checkmark$ & & $\checkmark$ \\
\hline Washington & $\checkmark$ & $\checkmark$ & $\checkmark$ & $\checkmark$ & $\checkmark$ & & & & & \\
\hline Vermont & $\checkmark$ & $\checkmark$ & $\checkmark$ & & & & $\checkmark$ & & & \\
\hline Hawaii & $\checkmark$ & $\checkmark$ & $\checkmark$ & $\checkmark$ & & & & & & \\
\hline Illinois & $\checkmark$ & $\checkmark$ & $\checkmark$ & $\checkmark$ & & & & & & $\checkmark$ \\
\hline Delaware & $\checkmark$ & & & $\checkmark$ & & & & & $\checkmark$ & $\checkmark$ \\
\hline
\end{tabular}


Table A3 (continued): Religious Liberty Protections in Same-Sex Marriage States

\begin{tabular}{|c|c|c|c|c|c|c|c|c|c|c|}
\hline & 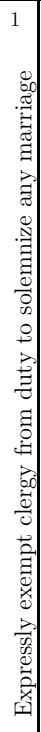 & 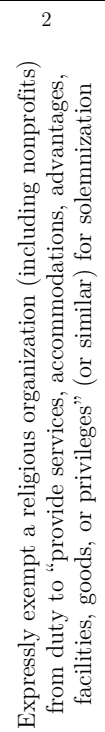 & 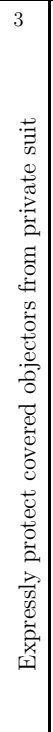 & 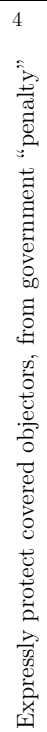 & 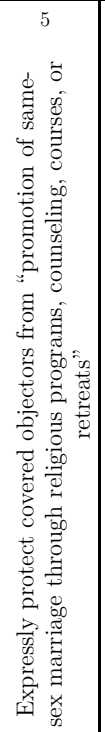 & 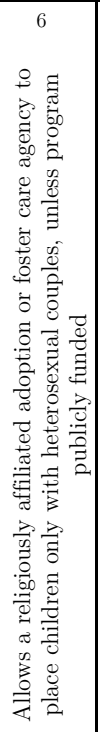 & 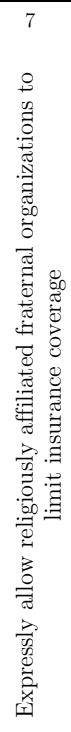 & 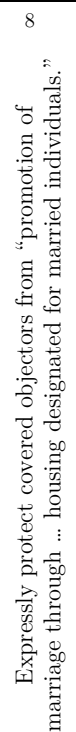 & 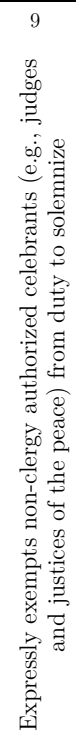 & 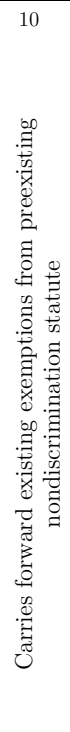 \\
\hline \multicolumn{11}{|c|}{ Same-Sex Marriage by Ballot Initiative } \\
\hline Maine & $\checkmark$ & $\checkmark$ & $\checkmark$ & $\checkmark$ & & & & & & \\
\hline \multicolumn{11}{|c|}{ Same-Sex Marriage by Judicial Decision } \\
\hline California & $\checkmark$ & & & $\checkmark$ & & & & & & * \\
\hline \multicolumn{11}{|l|}{ Iowa } \\
\hline \multicolumn{11}{|c|}{ Massachusetts } \\
\hline \multicolumn{11}{|l|}{ New Jersey } \\
\hline New Mexico & $*$ & & & & & & & & & $*$ \\
\hline \multicolumn{11}{|l|}{ Oklahoma $^{331}$} \\
\hline $\mathrm{Utah}^{332}$ & & & & & & & & & & \\
\hline
\end{tabular}

320. See Conn. Gen. Stat. § 46b-22b (West 2009); Del. Code Ann. tit. 13, § 106 (2013), http://delcode.delaware.gov/title13/c001/sc01/index. shtml; D.C. CoDE $\S$ 46-406(c) (LexisNexis 2012); S.B. No. 1 H.D.1 $\S$ 572-D, 27th Leg., 2nd Spec. Sess. (Haw. 2013); S.B. 10(a-5), 98th Gen. Assemb. Reg. Sess. (Ill. 2013); Md. Code AnN., Fam. Law $\S \S 2-201,2-$ 202, (LexisNexis 2012)); Minn. Stat. AnN. § 517.09 (West Supp. 2013); N.H. Rev. Stat. AnN. § 457:37(II) (Supp. 2013); N.Y. Dom. Rel. LAW § 11(1) (McKinney Supp. 2014); Vt. Stat. Ann. tit. 18, § 5144(b) (2012); R.I. Gen. LaWs AnN. § 15-3-6.1(b) (LexisNexis 2013); WASH. Rev. Code $\S 26.04 .010(4)$ (LexisNexis 2013). See also Me. Rev. Stat. Ann. tit. 19-A, § 655 (Supp. 2013). See also CAL. FAm. Code $\S 400$ (West Supp. 2013) ("Although marriage is a personal relation arising out of a civil, and not a religious, contract, a marriage may be solemnized by any of the following who is 18 years of age or older: (a) A priest, minister, rabbi, or authorized person of any religious denomination. A person authorized by this subdivision shall not be required to solemnize a marriage that is contrary to the tenets of his or her faith. Any refusal to solemnize a marriage under this subdivision, either by an individual or by a religious denomination, shall not affect 
the tax-exempt status of any entity."); Griego v. Oliver, 316 P.3d. 865, 871 (N.M. 2013) ("Our holding will not interfere with the religious freedom of religious organizations or clergy because (1) no religious organization will have to change its policies to accommodate samegender couples, and (2) no religious clergy will be required to solemnize a marriage in contravention of his or her religious beliefs.").

321. See Conn. Gen. Stat. §§ 46b-22b, 46b-35a (West 2009 \& Supp. 2013); D.C. Code $\S$ 46-406(e) (LexisNexis Supp. 2013); S.B. No. 1 H.D.1 § 572-E (Haw. 2013); S.B. 10 (a-10) (Ill. 2013) (covers "facility" only; organizations with "principal purpose" to advance religion); MD. Code AnN., Fam. Law $\S \S 2-201,2-202$ (LexisNexis 2012); Minn. Stat. Ann. § 363A.26(3) (West Supp. 2013); N.H. Rev. Stat. AnN. § 457:37(III) (Supp. 2013); N.Y. Dom. Rel. LaW § 10-b(1) (McKinney Supp. 2014); Vt. Stat. AnN. tit. 8, $\S$ 4501(1) (Supp. 2013); R.I. Gen. Laws AnN. § 15-3-6.1(c) (2013); Wash. Rev. Code Ann. § 26.04.010(5) (LexisNexis 2013). See also Me. Rev. Stat. Ann. tit. 19-A, § 655 (Supp. 2013) (provides there is no duty to "host"; encompasses "other religious institution").

322. See Conn. Gen. Stat. § 46b-35a (Supp. 2013); Del. Code Ann. tit. 13 $\S 106 \quad$ (2013), http://delcode.delaware.gov/title13/c001/sc01/ index.shtml; D.C. Code § 46-406(e)(2) (LexisNexis Supp. 2013); S.B. No. 1 H.D.1 § 572-D (Haw. 2013); S.B. 10 (a-5) (Ill. 2013); MD. Code AnN., Fam. Law §§ 2-201, 2-202 (LexisNexis 2012); Minn. Stat. AnN. § 517.09 (West Supp. 2013); N.H. Rev. Stat. AnN. § 457:37(III) (Supp. 2013); N.Y. Dom. Rel. Law § 10-b(1) (McKinney Supp. 2014); R.I. Gen. LawS Ann. § 15-3-6.1 (2013); VT. Stat. Ann. tit. 8, § 5144(b) (2012); Wash. Rev. Code $\S 26.04 .010(6)$ (LexisNexis 2013). See also Me. Rev. Stat. Ann. tit. 19-A, § 655 (Supp. 2013).

323. See Conn. Gen. Stat. § 46b-35a (Supp. 2013); Del. Code Ann. tit. 13 $\S 106 \quad$ (2013), http://delcode.delaware.gov/title13/c001/sc01/ index.shtml; D.C. Code $\S$ 46-406(e)(2) (LexisNexis Supp. 2013); S.B. No. 1 H.D.1 § 572-D-E (Haw. 2013); S.B. 10 (a-10) (Ill. 2013); Md. H.B. 438 §§ 2-3 (codified as MD. CodE AnN., Fam. Law §§ 2-201, 2-202 (LexisNexis 2012); Minn. Stat. Ann. § 517.09 (West Supp. 2013); N.H. Rev. Stat. AnN. § 457:37(III) (Supp. 2013); N.Y. Dom. REL. LAW § 10-b(1) (McKinney Supp. 2014); R.I. Gen. LaWs AnN. § 15-3-6.1 (2013); Wash. Rev. Code $\S 26.04 .010(4)$ (LexisNexis 2013). See also Me. Rev. Stat. tit. 19-A, § 655 (Supp. 2013). See also CAL. FAm. Code $\S 400(a)$ (West Supp. 2014) ("Any refusal to solemnize a marriage under this subdivision, either by an individual or by a religious denomination, shall not affect the taxexempt status of any entity.").

324. See D.C. Code $\S 46-406(e)$ (2011) (LexisNexis Supp. 2013). See also N.H. Rev. Stat. Ann. § 457:37(III) (Supp. 2013) (exempting "the promotion of marriage through religious counseling, programs, courses, retreats, or housing designated for married individuals"); MD. Code AnN., Fam. Law $\S \S 2-201,2-202$ (LexisNexis 2012) (this protection only applies if the program receives no state or federal funding); R.I. GEN. LAWs ANN. § 15-36.1 (2013) (exempting the "promotion of marriage through any social or religious programs or service"); WASH. REV. CODE ANN. § 26.04.010(7)(a)(ii (LexisNexis 2013)). New York may protect this. See N.Y. Dom. REL. LAW § 10-b(2) (McKinney Supp. 2014) ("nothing in this article shall limit or diminish the right,. . . of any religious or denominational institution or organization, or any organization operated for charitable or educational purposes, which is operated, supervised or controlled by or in connection with a religious organization ... from taking such action as is 
calculated by such organization to promote the religious principles for which it is established or maintained").

325. See Conn. Pub. Acts No. 09-13 § 19 (2009) (requiring that "such religious organization does not receive state or federal funds for that specific program or purpose"); Md. Code Ann., Fam. Law §§ 2-201, 2-202 (LexisNexis 2012) (no "promotion" through "social programs ... unless state or federal funds" for "specific program"); Minn. Stat. Ann. § 517.201 (West Supp. 2014) (conditioning protection on fact that covered entity "does not receive public funds for that specific program or purpose"). Rhode Island does not condition this protection on not receiving public funds. R.I. Gen. Laws Ann. § 15-3-6.1(c)(2) (2013).

326. See Vt. Stat. Ann. tit. 8 § 4501(b) (Supp. 2013); N.H. Rev. Stat. Ann. $\S 457: 37(\mathrm{IV})$ (Supp. 2013); MD. Code Ann., Fam. Law §§ 2-201, 2-202 (LexisNexis 2012); R.I. Gen. Laws Ann. § 15-3-6.1(e) (2013).

327. See N.H. Rev. Stat. Ann. § 457:37(III) (Supp. 2013). See also N.Y. Dom. REL. LAW § 10-b(2) (McKinney Supp. 2014) ("[N]othing in this article shall limit or diminish the right, . . . of any religious or denominational institution or organization, or any organization operated for charitable or educational purposes, which is operated, supervised or controlled by or in connection with a religious organization to limit employment or sales or rental of housing accommodations or admission to or give preference to persons of the same religion or denomination"); Minn. Stat. AnN. § 363A.26 (West 2013) (providing that religious organization are not prohibited from "in matters relating to sexual orientation, taking any action with respect to . . . housing and real property"). See also N.M. STAT. AnN. $\S$ 28-1-9 (West Supp. 2012) ("B. bar any religious or denominational institution or organization that is operated, supervised or controlled by or that is operated in connection with a religious or denominational organization from limiting admission to or giving preference to persons of the same religion or denomination or from making selections of buyers, lessees or tenants as are calculated by the organization or denomination to promote the religious or denominational principles for which it is established or maintained, unless membership in the religious or denominational organization is restricted on account of race, color, national origin or ancestry; C. bar any religious or denominational institution or organization that is operated, supervised or controlled by or that is operated in connection with a religious or denominational organization from imposing discriminatory employment or renting practices that are based upon sexual orientation or gender identity; provided, that the provisions of the Human Rights Act with respect to sexual orientation and gender identity shall apply to any other:(1) for-profit activities of a religious or denominational institution or religious organization subject to the provisions of Section 511(a) of the Internal Revenue Code of 1986, as amended; or(2) nonprofit activities of a religious or denominational institution or religious organization subject to the provisions of Section 501(c)(3) of the Internal Revenue Code of 1986, as amended").

328. Del. Code AnN. tit. $13 \S 106$ (2013), http://delcode.delaware.gov/ title13/c001/sc01/index.shtml ("[N]othing in this section shall be construed to require any person (including any clergyperson or minister of any religion) authorized to solemnize a marriage to solemnize any marriage, and no such authorized person who fails or refuses for any reason to solemnize a marriage shall be subject to any fine or other penalty for such failure or refusal."). 
329. See N.H. Rev. Stat. AnN. § 457:37 ("Nothing in this chapter shall be deemed or construed to limit the protections and exemptions provided to religious organizations under RSA 354-A:18."); SF 925, 85th Legis. Reg. Sess. (Minn. 2013) ("This chapter does not alter or affect the protections or exemptions provided in chapter $363 \mathrm{~A}$ for a religious association, educational institution, business, labor union, place of public accommodation, employer, or other person."); S.B. 10, 98th Gen. Assem. Reg. Sess. (Ill. 2013) ("Nothing in this Act . . . is it intended to abrogate, limit, or expand the Illinois Human Rights Act or the Religious Freedom Restoration Act."); R.I. GEN. LAws ANN. § 15-3-6.1 "Nothing in the marriage laws of this state shall be deemed or construed to limit the protections and exemptions provided to religious organizations under GL paragraph 28-5-6(7)(ii) and subsection 34-37-4.2(a)"); 3. N.Y. Dom. Rel. Law § 10-b. ("Nothing in this section shall be deemed or construed to limit the protections and exemptions otherwise provided to religious organizations under section three of article one of the constitution of the state of New York."). A catch-all provision in Delaware provides that the same-sex marriage law "does not affect rights, duties or obligations that matured or were owed, penalties that were incurred, or proceedings that were begun, before its effective date." Delaware Laws Ch. 19 (H.B. 75 2013). See also In re Marriage Cases, 43 Cal. 4th 757, 784, 183 P.3d 384, 452 (2008), vacated by Hollingsworth v. Perry, 113 S. Ct. 2652 (2013) ("[a]ffording same-sex couples the opportunity to obtain the designation of marriage will not impinge upon the religious freedom of any religious \organization, official, or any other person; no religion will be required to change its religious policies or practices with regard to same-sex couples, and no religious officiant will be required to solemnize a marriage in contravention of his or her religious beliefs. (CAL. Const., art. I, § 4.)."); Griego v. Oliver, 316 P.3d. 865 ("Our holding will not interfere with the religious freedom of religious organizations or clergy because (1) no religious organization will have to change its policies to accommodate same-gender couples, and (2) no religious clergy will be required to solemnize a marriage in contravention of his or her religious beliefs. )

330. Connecticut passed legislation on the heels of a judicial decision requiring same-sex marriage. See Kerrigan v. Commissioner of Public Health, 957 A.2d 407(2008).

331. Bishop v. U.S. ex rel. Holder, No. 04-CV-848-TCK-TLW, 2014 WL 116013, at *33 (N.D. Okla. Jan 14, 2014) (permanently enjoining Oklahoma's constitutional same-sex marriage ban because it "violates the Equal Protection Clause of the Fourteenth Amendment to the U.S. Constitution by precluding same-sex couples from receiving an Oklahoma marriage license."). The court stayed execution of the permanent injunction pending any appeals in the Tenth Circuit. Id.

332. Kitchen v. Herbert, No. 2:13-cv-217, 2013 WL 6697874, at *27 (D. Utah Dec. 20, 2013) ("Although the State did not directly present an argument based on religious freedom, the court notes that its decision does not mandate any change for religious institutions, which may continue to express their own moral viewpoints and define their own traditions about marriage. If anything, the recognition of same-sex marriage expands religious freedom because some churches that have congregations in Utah desire to perform same-sex wedding ceremonies but are currently unable to do so, . . . By recognizing the right to marry a partner of the same sex, the State allows these groups the freedom to practice their religious beliefs without mandating that other groups must adopt similar practices."). 
Case Western Reserve Law Review · Volume $64 \cdot$ Issue $3 \cdot 2014$

Marriage of Necessity

Table A4: State Political Climate Cl33 $^{33}$

\begin{tabular}{|c|c|c|c|c|c|c|c|}
\hline \multirow[t]{2}{*}{ State } & \multirow[t]{2}{*}{ Region } & \multicolumn{2}{|c|}{ House 2013} & \multicolumn{2}{|c|}{ Senate 2013} & \multirow{2}{*}{$\begin{array}{c}\text { Gov. } \\
\begin{array}{c}\text { D/R } \\
\text { (Ind.) }\end{array}\end{array}$} & \multirow[t]{2}{*}{$\begin{array}{c}\text { Constitutional } \\
\text { Ban } \\
\end{array}$} \\
\hline & & 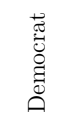 & 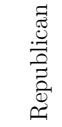 & 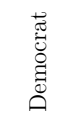 & 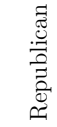 & & \\
\hline Alabama & South & 37 & 63 & 11 & 23 & $\mathrm{R}$ & $\mathrm{X}$ \\
\hline Alaska & Pacific & 14 & 26 & 7 & 13 & $\mathrm{R}$ & $\mathrm{X}$ \\
\hline Arizona & West & 24 & 36 & 13 & 16 & $\mathrm{R}$ & $\mathrm{X}$ \\
\hline Arkansas & South & 48 & 51 & 13 & 21 & $\mathrm{D}$ & $\mathrm{X}$ \\
\hline California & West & 52 & 25 & 28 & 12 & $\mathrm{D}$ & \\
\hline Colorado & West & 37 & 38 & 18 & 17 & $\mathrm{D}$ & $\mathrm{X}$ \\
\hline Connecticut & Northeast & 98 & 53 & 22 & 14 & $\mathrm{D}$ & \\
\hline Delaware & South & 27 & 14 & 13 & 8 & $\mathrm{D}$ & \\
\hline $\mathrm{DC}$ & South & & & & & - & \\
\hline Florida & South & 44 & 75 & 14 & 26 & $\mathrm{R}$ & $\mathrm{X}$ \\
\hline Georgia & South & 58 & 118 & 18 & 37 & $\mathrm{R}$ & $\mathrm{X}$ \\
\hline Hawaii & Pacific & 44 & 7 & 24 & 1 & $\mathrm{D}$ & \\
\hline Idaho & West & 13 & 57 & 7 & 28 & $\mathrm{R}$ & $\mathrm{X}$ \\
\hline Illinois & Midwest & 71 & 47 & 40 & 19 & D & \\
\hline Indiana & Midwest & 31 & 68 & 13 & 37 & $\mathrm{R}$ & \\
\hline Iowa & Midwest & 46 & 53 & 26 & 23 & $\mathrm{R}$ & \\
\hline Kansas & Midwest & 32 & 91 & 8 & 32 & $\mathrm{R}$ & $\mathrm{X}$ \\
\hline Kentucky & South & 54 & 45 & 14 & 23 & D & $\mathrm{X}$ \\
\hline Louisiana & South & 43 & 59 & 13 & 26 & $\mathrm{R}$ & $\mathrm{X}$ \\
\hline Maine & Northeast & 89 & 58 & 19 & 15 & $\mathrm{R}$ & \\
\hline Maryland & South & 98 & 43 & 34 & 11 & $\mathrm{D}$ & \\
\hline Massachusetts & Northeast & 130 & 29 & 36 & 3 & $\mathrm{D}$ & \\
\hline Michigan & Midwest & 49 & 59 & 12 & 26 & $\mathrm{R}$ & $\mathrm{X}$ \\
\hline Minnesota & Midwest & 73 & 61 & 39 & 28 & $\mathrm{D}$ & \\
\hline Mississippi & south & 58 & 64 & 20 & 32 & $\mathrm{R}$ & $\mathrm{X}$ \\
\hline
\end{tabular}

333. Sources: Region: Chapter 6-Statistical Groupings of States and Counties, U.S. Census Bureau (last accessed Jan. 31, 2014) available at: http://www.census.gov/geo/reference/pdfs/GARM/Ch6GARM.pdf; House, Senate, and Governor data drawn from ballotpedia.org; Constitutional ban and lock-in effect, see Part II.D; Sexual Orientation Protection: States With Protections for Being Gay, N.Y. Times (May 31, 2013), http://www. nytimes.com/interactive/2013/05/31/business/States-With-Protections-forBeing-Gay.html?ref=your-money; Education: Educational Attainment, US Census Bureau (2011) available at: http://www.census.gov/ hhes/socdemo/education/; Religiosity from State of the States, Gallop, (2012) available at: http://www.gallup.com/poll/125066/state-states.aspx; Nate Silver, How Opinion on Same-Sex Marriage Is Changing, and What It Means New York Times (Mar. 26 2013) available at http://fivethirtyeight.blogs.nytimes.com/2013/03/26/how-opinion-on-samesex-marriage-is-changing-and-what-it-means/?_r $=0$. 
Case Western Reserve Law Review · Volume $64 \cdot$ Issue $3 \cdot 2014$ Marriage of Necessity

Table A4 (continued): State Political Climate

\begin{tabular}{|c|c|c|c|c|c|c|c|c|}
\hline \multirow[t]{2}{*}{ State } & \multirow{2}{*}{ 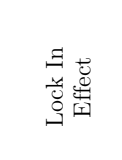 } & \multirow{2}{*}{ 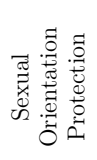 } & \multirow{2}{*}{ 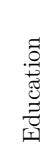 } & \multirow{2}{*}{$\begin{array}{c}\begin{array}{c}\text { Religiosity } \\
2012\end{array} \\
\begin{array}{c}\% \text { very } \\
\text { religious }\end{array}\end{array}$} & \multicolumn{4}{|c|}{ Nate Silver's Projected Support } \\
\hline & & & & & 2008 & 2012 & 2016 & 2020 \\
\hline Alabama & Mild & No & 30 & 55.7 & 24.4 & 29.9 & 35.9 & 42.5 \\
\hline Alaska & Mild & No & 36 & 31.3 & 41.5 & 47.6 & 53.7 & 59.6 \\
\hline Arizona & Negligible & No & 35 & 36.6 & 42.4 & 48.4 & 54.6 & 60.7 \\
\hline Arkansas & Negligible & No & 25 & 52.3 & 31.1 & 36.8 & 42.8 & 49.1 \\
\hline California & & & 41 & 34.5 & 48.6 & 54.6 & 60.4 & 66.1 \\
\hline Colorado & Strong & Yes & 49 & 33.5 & 45.8 & 52 & 58 & 64 \\
\hline Connecticut & & & 51 & 30.5 & 52 & 58.2 & 64.1 & 69.8 \\
\hline Delaware & & & 40 & 35.2 & 49.2 & 55.7 & 62 & 68 \\
\hline $\mathrm{DC}$ & & & 77 & 29.7 & 57.1 & 63.1 & 68.7 & 74 \\
\hline Florida & Negligible & No & 34 & 37.6 & 40.4 & 46.6 & 52.9 & 59.3 \\
\hline Georgia & Strong & No & 37 & 47.9 & 30.8 & 36.7 & 42.9 & 49.5 \\
\hline Hawaii & & & 40 & 31.4 & 52.2 & 58.6 & 64.6 & 70.3 \\
\hline Idaho & Strong & No & 31 & 45.1 & 36.4 & 42.4 & 48.5 & 54.8 \\
\hline Illinois & & & 42 & 38 & 45.8 & 52.2 & 58.4 & 64.6 \\
\hline Indiana & & & 31 & 42.7 & 37.8 & 43.7 & 49.8 & 55.9 \\
\hline Iowa & & & 33 & 41.3 & 40.2 & 46.5 & 52.8 & 59.1 \\
\hline Kansas & Strong & No & 40 & 45.1 & 36.8 & 42.8 & 48.9 & 55.1 \\
\hline Kentucky & Mild & No & 30 & 45.4 & 35.7 & 41.8 & 48 & 54.4 \\
\hline Louisiana & Strong & No & 28 & 53.3 & 29.3 & 35.1 & 41.4 & 48.1 \\
\hline Maine & & & 37 & 24.4 & 44.8 & 51.1 & 57.2 & 63.2 \\
\hline Maryland & & & 52 & 36.7 & 48.6 & 55 & 61.2 & 67.2 \\
\hline Massachusetts & & & 55 & 26.5 & 56.4 & 62.9 & 69 & 74.5 \\
\hline Michigan & Negligible & No & 34 & 36.5 & 42.7 & 48.9 & 55 & 61.2 \\
\hline Minnesota & & & 42 & 38.2 & 46.3 & 52.3 & 58.2 & 64 \\
\hline Mississippi & Mild & No & 27 & 58.4 & 20.9 & 25.9 & 31.5 & 37.8 \\
\hline
\end{tabular}


Case Western Reserve Law Review · Volume $64 \cdot$ Issue $3 \cdot 2014$ Marriage of Necessity

\section{Table A4 (continued): State Political Climate}

\begin{tabular}{|c|c|c|c|c|c|c|c|}
\hline \multirow[t]{2}{*}{ State } & \multirow[t]{2}{*}{ Region } & \multicolumn{2}{|c|}{ House 2013} & \multicolumn{2}{|c|}{ Senate 2013} & \multirow{2}{*}{$\begin{array}{c}\text { Gov. } \\
\\
\text { D/R } \\
\text { (Ind.) }\end{array}$} & \multirow{2}{*}{$\begin{array}{c}\text { Constitutional } \\
\text { Ban }\end{array}$} \\
\hline & & $\begin{array}{l}\overrightarrow{\widetilde{d}} \\
\mathbb{U} \\
\stackrel{0}{0} \\
0\end{array}$ & 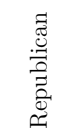 & 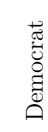 & 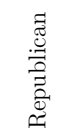 & & \\
\hline Missouri & Midwest & 53 & 109 & 10 & 24 & $\mathrm{D}$ & $\mathrm{X}$ \\
\hline Montana & West & 39 & 61 & 21 & 29 & $\mathrm{D}$ & $\mathrm{X}$ \\
\hline Nebraska & Midwest & 0 & 0 & 0 & 0 & $\mathrm{R}$ & $\mathrm{X}$ \\
\hline Nevada & West & 26 & 15 & 11 & 10 & $\mathrm{R}$ & $\mathrm{X}$ \\
\hline $\begin{array}{c}\text { New } \\
\text { Hampshire }\end{array}$ & Northeast & 218 & 179 & 11 & 13 & D & \\
\hline New Jersey & Northeast & 47 & 32 & 24 & 16 & $\mathrm{R}$ & \\
\hline New Mexico & West & 37 & 32 & 25 & 17 & $\mathrm{R}$ & \\
\hline New York & Northeast & 105 & 42 & 33 & 30 & $\mathrm{D}$ & \\
\hline $\begin{array}{c}\text { North } \\
\text { Carolina }\end{array}$ & South & 42 & 77 & 17 & 33 & $\mathrm{R}$ & $\mathrm{X}$ \\
\hline $\begin{array}{l}\text { North } \\
\text { Dakota }\end{array}$ & Midwest & 23 & 71 & 14 & 33 & $\mathrm{R}$ & $\mathrm{X}$ \\
\hline Ohio & Midwest & 38 & 61 & 10 & 23 & $\mathrm{R}$ & $\mathrm{X}$ \\
\hline Oklahoma & South & 29 & 72 & 12 & 36 & $\mathrm{R}$ & Ruled Uncon. \\
\hline Oregon & West & 34 & 26 & 16 & 14 & $\mathrm{D}$ & $\mathrm{X}$ \\
\hline $\begin{array}{c}\text { Pennsylvani } \\
\mathrm{a} \\
\end{array}$ & Northeast & 92 & 110 & 23 & 27 & $\mathrm{R}$ & \\
\hline Rhode Island & Northeast & 69 & 6 & 32 & 5 & Ind. & \\
\hline $\begin{array}{c}\text { South } \\
\text { Carolina }\end{array}$ & South & 45 & 78 & 18 & 28 & $\mathrm{R}$ & $\mathrm{X}$ \\
\hline $\begin{array}{c}\text { South } \\
\text { Dakota }\end{array}$ & Midwest & 17 & 53 & 7 & 27 & $\mathrm{R}$ & $\mathrm{X}$ \\
\hline Tennessee & South & 27 & 70 & 7 & 26 & $\mathrm{R}$ & $\mathrm{X}$ \\
\hline Texas & South & 54 & 95 & 12 & 19 & $\mathrm{R}$ & $\mathrm{X}$ \\
\hline Utah & West & 14 & 61 & 5 & 24 & $\mathrm{R}$ & Ruled Uncon. \\
\hline Vermont & Northeast & 94 & 45 & 21 & 7 & $\mathrm{D}$ & \\
\hline Virginia & South & 32 & 65 & 20 & 20 & $\mathrm{R}$ & $\mathrm{X}$ \\
\hline Washington & West & 55 & 43 & 26 & 23 & $\mathrm{D}$ & \\
\hline $\begin{array}{c}\text { West } \\
\text { Virginia }\end{array}$ & South & 53 & 46 & 24 & 10 & $\mathrm{D}$ & \\
\hline Wisconsin & Midwest & 39 & 57 & 15 & 18 & $\mathrm{R}$ & $\mathrm{X}$ \\
\hline Wyoming & West & 8 & 52 & 4 & 26 & $\mathrm{R}$ & \\
\hline
\end{tabular}


Case Western Reserve Law Review · Volume $64 \cdot$ Issue $3 \cdot 2014$ Marriage of Necessity

Table A4 (continued): State Political Climate

\begin{tabular}{|c|c|c|c|c|c|c|c|c|}
\hline \multirow[t]{2}{*}{ State } & \multirow{2}{*}{ 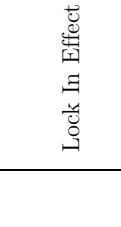 } & \multirow{2}{*}{ 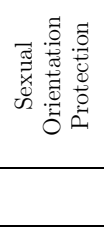 } & \multirow{2}{*}{ 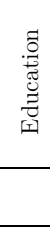 } & \multirow{2}{*}{$\begin{array}{c}\text { Religiosity } \\
2012 \\
\text { \% very } \\
\text { religious }\end{array}$} & \multicolumn{4}{|c|}{ Nate Silver's Projected Support } \\
\hline & & & & & 2008 & 2012 & 2016 & 2020 \\
\hline Missouri & Mild & No & 35 & 42.1 & 37.5 & 43.6 & 49.7 & 56 \\
\hline Montana & Mild & No & 36 & 34 & 41.9 & 47.8 & 53.7 & 59.6 \\
\hline Nebraska & Strong & No & 36 & 44.2 & 37.9 & 44 & 50.2 & 56.5 \\
\hline Nevada & Mild & Yes & 29 & 31.4 & 46.7 & 53 & 59.2 & 65.2 \\
\hline $\begin{array}{c}\text { New } \\
\text { Hampshire }\end{array}$ & & & 43 & 23.4 & 50.6 & 57.1 & 63.2 & 69.1 \\
\hline New Jersey & & & 47 & 34.7 & 50.6 & 57 & 63.1 & 69 \\
\hline New Mexico & & & 36 & 43.2 & 43.3 & 49.6 & 55.8 & 61.9 \\
\hline New York & & & 46 & 31.5 & 51.9 & 58.1 & 64 & 69.7 \\
\hline $\begin{array}{c}\text { North } \\
\text { Carolina } \\
\end{array}$ & Strong & No & 35 & 49.5 & 34.2 & 40.2 & 46.3 & 52.7 \\
\hline $\begin{array}{l}\text { North } \\
\text { Dakota }\end{array}$ & Negligible & No & 33 & 41.6 & 38.5 & 44.8 & 51.2 & 57.7 \\
\hline Ohio & Mild & No & 33 & 38.2 & 40.4 & 46.6 & 52.8 & 59.1 \\
\hline Oklahoma & Mild & No & 30 & 47.6 & 32.5 & 38.4 & 44.7 & 51.2 \\
\hline Oregon & Mild & Yes & 40 & 28.8 & 48 & 54 & 59.7 & 65.4 \\
\hline Pennsylvania & & & 37 & 39.5 & 45.8 & 52 & 58 & 64 \\
\hline Rhode Island & & & 42 & 29.1 & 56.3 & 63.1 & 69.3 & 75.1 \\
\hline $\begin{array}{c}\text { South } \\
\text { Carolina }\end{array}$ & Strong & No & 32 & 51.9 & 31.6 & 37.3 & 43.3 & 49.7 \\
\hline $\begin{array}{c}\text { South } \\
\text { Dakota }\end{array}$ & Mild & No & 32 & 45.6 & 37.1 & 43.3 & 49.7 & 56.1 \\
\hline Tennessee & Mild & No & 31 & 50.3 & 34.5 & 40.3 & 46.3 & 52.6 \\
\hline Texas & Strong & No & 34 & 47 & 33.4 & 39.4 & 45.8 & 52.4 \\
\hline Utah & Strong & No & 38 & 56 & 36.3 & 42.1 & 48.1 & 54.2 \\
\hline Vermont & & & 46 & 19.1 & 51.6 & 57.8 & 63.8 & 69.4 \\
\hline Virginia & Mild & No & 48 & 41.1 & 41.1 & 47.2 & 53.3 & 59.5 \\
\hline Washington & & & 42 & 30.5 & 49.6 & 55.7 & 61.5 & 67.2 \\
\hline $\begin{array}{c}\text { West } \\
\text { Virginia }\end{array}$ & & & 24 & 41.9 & 37.3 & 43.5 & 49.9 & 56.3 \\
\hline Wisconsin & Mild & Yes & 34 & 36.7 & 45.6 & 51.8 & 58 & 64 \\
\hline Wyoming & & & 31 & 32.8 & 34.6 & 40.6 & 46.8 & 53.2 \\
\hline
\end{tabular}


Case Western Reserve Law Review · Volume 64 - Issue $3 \cdot 2014$ Marriage of Necessity

Table A5: Vote Margins in Enacting Jurisdictions ${ }^{334}$

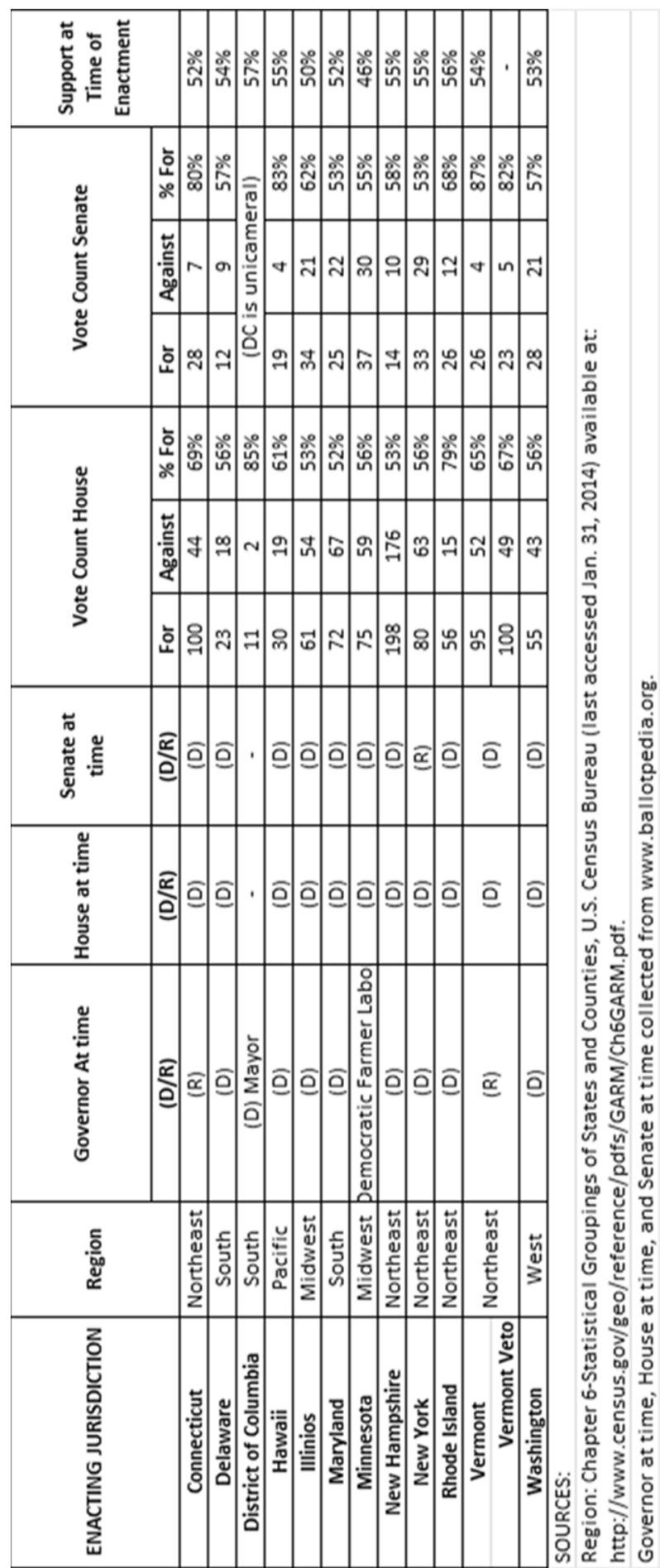


334. Support at time of enactment: Connecticut Voters Back Same-Sex Marriage, Quinnipiac University Poll Finds; Rell Approval Holds as Dodd, Lieberman Scores Drop, QuinniPiac Univ. (Dec. 17, 2008), http://www.quinnipiac.edu/institutes-and-centers/polling-institute/ connecticut/release-detail?ReleaseID=1243; New Poll: 54\% of Delaware Voters Support Marriage Equality Del. Equality (Mar. 4, 2013), https://d3n8a8pro7vhmx.cloudfront.net/equalitydelaware/pages/54/ attachments/original/1362425933/Equality_Delaware_Press_Release_New_Poll_54_Support.pdf?1362425933; D.C. Poll, WAsh. PosT (2010), http://www.washingtonpost.com/wp-srv/politics/polls/postpoll 013110.html; Poll: Hawaii Voters Support Allowing Gay Couples to Marry, Civil BeAT (Jan. 28, 2013, 3:18 PM HST), http://hawaii.politics.government.blogs.civilbeat.com/post/41745936105 /poll-hawaii-voters-support-allowing-gay-couples-to; Greg Hinz, Illinoisans back gay marriage 50-29: Crain's/Ipsos poll, CRAIN's Chicago Business (Feb. 19, 2013), http://www.chicagobusiness.com/ article/20130219/BLOGS02/130219779/illinoisans-back-gay-marriage-5029-crains-ipsos-poll\#; Question 6 Civil Marriage Protection Act, MD. State BoArd of Elections (Nov. 28, 2012), http://elections. state.md.us/elections/2012/results/general/gen_detail_qresults_2012_4 0006S-.html; Minnesotans like Dayton, Split on Gay marriage, PubliC Policy Polling (June 1, 2011), http://www.publicpolicypolling.com/ pdf/PPP_Release_MN_06011118.pdf; New Poll Shows Majority of New Hampshire Voters Continue to Support Marriage Equality for Lesbian and Gay Couples, National Center for Lesbian Rights (2009), http://nclrights.wordpress.com/2009/04/28/new-poll-shows-majority-ofnew-hampshire-voters-continue-to-support-marriage-equality-for-lesbianand-gay-couples/; 8/10: Majority Supports Legalization of Same-Sex Marriage...63\% Want Law to Remain in Place, MARIST Poll (Aug. 10, 2011), http://maristpoll.marist.edu/810-majority-supports-legalizationof-same-sex-marriage\%E2\%80\% A663-want-law-to-remain-in-place/ \#sthash.gIbZUN2p.dpuf; Ted Nesi, Poll: Raimondo is favorite for gov; Chafee does best as a Dem, WPRI. (Jan. 31, 2013), http://blogs.wpri.com/2013/01/31/poll-raimondo-is-favorite-for-govchafees-best-shot-as-dem/; Minnesota Amendment 1 Same-Sex Marriage Ballot Measure Fails, Huffington Post (Nov. 7, 2012), http:// www.huffingtonpost.com/2012/11/07/minnesota-amendment-1-results2012_n_2050310.html; Vote Counts: Substitute for Raised S.B. No. 899, Session Year 2009, Conn. Gen. Assem., http://www. cga.ct.gov/asp/cgabillstatus/cgabillstatus.asp?selBillType=Bill\&bill_nu $\mathrm{m}=899 \&$ which_year=2009; Zach Ford, Delaware Becomes 11th State with Marriage Equality, THINK Progress (May 7, 2013) http://thinkprogress.org/lgbt/2013/05/07/1975311/breaking-delawareto-become-11th-state-with-marriage-equality/; Governor Signs Marriage Equality Bill into Law, State OF Delaware (May 7, 2013), http://news.delaware.gov/2013/05/07/governor-signs-marriage-equalitybill-into-law/; Ian Urbina, District of Columbia Backs Same-Sex Marriage, N.Y. Times, Dec. 16, 2009, at A28; Abercrombie signs samesex marriage bill into law, Honolulu StAR-Advertiser (Nov. 13, 2013), http://www.staradvertiser.com/news/breaking/20131113 Abercrombie_to_sign_samesex_marriage_bill_into_law.html; Reid Wilson, Hawaii Set to Legalize Same Sex Marriage, WAshington Post, Nov. 13, 2013, at A2; Dave Mckinney, Gay marriage bill passes state 
House, Senate - heads to Quinn's desk, Chicago Sun-Times (Dec. 7, 2013 6:25 AM), http://www.suntimes.com/23558841-761/gay-marriagebill-passes-in-illinois-house.html; Ill. S., S, Vote: S.B. $103^{\text {rd }}$ Reading, $98^{\text {th }}$ Gen. Assem. at 1 (2013); Ill. H., H. Vote: S.B. $103^{\text {rd }}$ Reading, $98^{\text {th }}$ Gen. Assem., at 4 (2013); David Hill, Maryland senate approves same-sex marriage bill, WASH. Times (Feb. 23, 2012), http://www.washington times.com/news/2012/feb/23/maryland-senate-approves-same-sexmarriage-bill/?utm_source=RSS_Feed\&utm_medium $=$ RSS; Bill Information: H.B. 4382012 Reg. Sess. ( $\overline{\mathrm{M}} \mathrm{d}$. 2012), http://mgaleg. maryland.gov/webmga/frmMain.aspx?ys=2012rs\%2fbillfile\%2fhb0438.ht m; HF 1054: Status in the House for the 88th Legislature (Minn. 2013), https://www.revisor.mn.gov/bills/bill.php?view $=$ chrono\&f $=$ HF1054\&y= 2013\&ssn $=0 \& b=$ house\#actions; Press Release, Empowering Spirits, Empowering Spirits Applauds Passage of NH Marriage Equality Bill, (Jun. 3, 2009), http://www.empoweringspirits.org/PRDocServer/ Passage_of_NH_Marriage_Equality_Bill_060309.pdf; A.B 8520-2011: N.Y. Open Legislation, N.Y. SEN. (2011), http://open.nysenate.gov/ legislation/bill/A8520-2011 (last visited Aug. 12, 2013); Randal Edgar, R.I. Senate approves same-sex marriage 26 to 12, PROvidence Journal (Apr. 24, 2013), http://news.providencejournal.com/breakingnews/2013/04/same-sex-marriage-bills-clear-rhode-island-senate.html;

Randal Edgar, Rhode Island House passes bill legalizing same-sex marriage, 56 to 15 (May 2, 2013), http://news.providencejournal.com/ breaking-news/2013/05/rhode-island-house-passes-same-sex-marriagebill-56-to-15.html; Journal of the House of Representatives, H. Vol. 140, No.41, May 2, Sess., at 11 (R.I. 2013); Journal of the Senate, S. Vol. 140, No.41, Apr. 24, Sess., at 8 (R.I. 2013); Status Summary: S. 115, VT. LEG. (2009), http://www.leg.state.vt.us/database/status/summary. cfm?Bill $=$ S.0115\&Session $=2010 ;$ Tom Watkins, Washington state legislature votes to approve same-sex marriage, CNN (Feb. 9, 2012), http://www.cnn.com/2012/02/08/us/washington-same-sexmarriage/index.html. 
Case Western Reserve Law Review · Volume $64 \cdot$ Issue $3 \cdot 2014$ Marriage of Necessity

Table A6: Same-Sex Marriage Support (and Opposition) in Constitutional Ban States

\begin{tabular}{|c|c|c|c|c|c|}
\hline \multicolumn{6}{|c|}{ Strong Lock-In } \\
\hline & $\begin{array}{l}\text { 1994-96 } \\
\text { Support }\end{array}$ & $\begin{array}{l}\text { Support at time } \\
\text { of Ban }\end{array}$ & $\begin{array}{l}2008 \\
\text { Support }\end{array}$ & $\begin{array}{l}\text { 2012 Support } \\
\text { (projected) }\end{array}$ & $\begin{array}{l}\text { 2016 Support } \\
\text { (projected) }\end{array}$ \\
\hline Georgia (2004) & 21 & 23.80 & 34 & 36.7 & 42.9 \\
\hline Idaho (2006) & 17 & 36.65 & 33 & 42.4 & 48.5 \\
\hline Kansas (2005) & 24 & 30.00 & 37 & 42.8 & 48.9 \\
\hline $\begin{array}{l}\text { Louisiana } \\
(2004)\end{array}$ & 23 & 22.22 & 36 & 35.1 & 41.4 \\
\hline $\begin{array}{l}\text { North Carolina } \\
(2012)\end{array}$ & 21 & 38.94 & 36 & 40.2 & 46.3 \\
\hline $\begin{array}{l}\text { South Carolina } \\
(2006)\end{array}$ & 21 & 22.00 & 32 & 37.3 & 43.3 \\
\hline Texas (2005) & 24 & 23.75 & 35 & 39.4 & 45.8 \\
\hline \multicolumn{6}{|c|}{ Mild Lock-In } \\
\hline & $\begin{array}{l}\text { 1994-96 } \\
\text { Support }\end{array}$ & $\begin{array}{l}\text { Support at time } \\
\text { of Ban }\end{array}$ & $\begin{array}{l}2008 \\
\text { Support }\end{array}$ & $\begin{array}{l}\text { 2012 Support } \\
\text { (projected) }\end{array}$ & $\begin{array}{l}\text { 2016 Support } \\
\text { (projected) }\end{array}$ \\
\hline $\begin{array}{l}\text { Alabama } \\
(2006)\end{array}$ & 17 & 19.00 & 26 & 29.9 & 35.9 \\
\hline Alaska (1998) & 23 & 31.89 & 45 & 47.6 & 53.7 \\
\hline $\begin{array}{l}\text { Kentucky } \\
(2004)\end{array}$ & 18 & 25.00 & 31 & 41.8 & 48 \\
\hline Nevada (2002) & 26 & 32.80 & 50 & 53 & 59.2 \\
\hline Oregon (2004) & 26 & 43.00 & 52 & 54 & 59.7 \\
\hline $\begin{array}{l}\text { Tennessee } \\
(2006)\end{array}$ & 19 & 19.00 & 31 & 40.3 & 46.3 \\
\hline Virginia (2006) & 24 & 42.94 & 42 & 47.2 & 53.3 \\
\hline $\begin{array}{l}\text { Wisonsin } \\
(2006)\end{array}$ & 26 & 41.00 & 44 & 51.8 & 58 \\
\hline \multicolumn{6}{|c|}{ Negligible Lock-In } \\
\hline & $\begin{array}{l}1994-96 \\
\text { Support }\end{array}$ & $\begin{array}{l}\text { Support at time } \\
\text { of Ban }\end{array}$ & $\begin{array}{l}2008 \\
\text { Support }\end{array}$ & $\begin{array}{l}\text { 2012 Support } \\
\text { (projected) }\end{array}$ & $\begin{array}{l}\text { 2016 Support } \\
\text { (projected) }\end{array}$ \\
\hline Arizona (2008) & 25 & 43.80 & 48 & 48.4 & 54.6 \\
\hline $\begin{array}{l}\text { Arkansas } \\
(2004)\end{array}$ & 17 & 25.05 & 29 & 36.8 & 42.8 \\
\hline $\begin{array}{l}\text { Colorado } \\
(2006)\end{array}$ & 27 & 44.98 & 52 & 52 & 58 \\
\hline Florida (2008) & 26 & 38.10 & 41 & 46.6 & 52.9 \\
\hline $\begin{array}{l}\text { Michigan } \\
(2004)\end{array}$ & 26 & 41.00 & 46 & 48.9 & 55 \\
\hline $\begin{array}{l}\text { Mississippi } \\
(2004)\end{array}$ & 17 & 14.00 & 27 & 25.9 & 31.5 \\
\hline $\begin{array}{l}\text { Missouri } \\
(2004)\end{array}$ & 26 & 29.40 & 37 & 43.6 & 49.7 \\
\hline $\begin{array}{l}\text { Montana } \\
(2004)\end{array}$ & 23 & 33.50 & 45 & 47.8 & 53.7 \\
\hline $\begin{array}{l}\text { Nebraska } \\
(2000)\end{array}$ & 20 & 29.90 & 35 & 44 & 50.2 \\
\hline $\begin{array}{l}\text { North Dakota } \\
(2004)\end{array}$ & 22 & 26.77 & 38 & 44.8 & 51.2 \\
\hline Ohio (2004) & 24 & 38.29 & 45 & 46.6 & 52.8 \\
\hline $\begin{array}{l}\text { South Dakota } \\
(2006)\end{array}$ & 23 & 48.17 & 38 & 43.3 & 49.7 \\
\hline
\end{tabular}


Case Western Reserve Law Review · Volume $64 \cdot$ Issue $3 \cdot 2014$ Marriage of Necessity

Table A\%: Support for Same-Sex Marriage by Age, With and Without the Oldest Generation (65 and Older) (335 $^{33}$

\begin{tabular}{|c|c|c|c|c|c|c|c|c|c|c|}
\hline $\begin{array}{c}\text { STATE/ } \\
\text { SUPPORT }\end{array}$ & $65+$ & $45-64$ & $30-44$ & $18-29$ & Average & $\begin{array}{l}\text { Weighted } \\
\text { Average }\end{array}$ & $18-29$ & $30-44$ & $45-64$ & $65+$ \\
\hline Massachusetts & 34 & 53 & 61 & 74 & 55.5 & 56.2 & 21.7 & 25.3 & 35.4 & 17.6 \\
\hline Vermont & 33 & 49 & 57 & 70 & 52.3 & 52.1 & 20.2 & 22.7 & 38.8 & 18.4 \\
\hline Rhode Island & 32 & 49 & 58 & 71 & 52.5 & 53.0 & 22.5 & 23.9 & 35.3 & 18.3 \\
\hline Connecticut & 32 & 49 & 57 & 69 & 51.8 & 51.8 & 19.7 & 25.0 & 36.9 & 18.4 \\
\hline New York & 32 & 47 & 56 & 70 & 51.3 & 51.8 & 22.3 & 25.9 & 34.4 & 17.4 \\
\hline $\begin{array}{c}\text { New } \\
\text { Hampshire }\end{array}$ & 31 & 47 & 56 & 69 & 50.8 & 50.6 & 19.1 & 24.3 & 39.3 & 17.3 \\
\hline Maine & 30 & 46 & 56 & 69 & 50.3 & 49.2 & 17.9 & 23.1 & 39.0 & 20.1 \\
\hline California & 31 & 46 & 53 & 67 & 49.3 & 50.7 & 23.9 & 27.7 & 33.2 & 15.2 \\
\hline Washington & 28 & 45 & 53 & 66 & 48.0 & 49.0 & 22.1 & 26.4 & 35.4 & 16.1 \\
\hline Hawaii & 27 & 46 & 53 & 66 & 48.0 & 48.6 & 21.5 & 25.1 & 35.0 & 18.4 \\
\hline New Jersey & 27 & 45 & 53 & 67 & 48.0 & 48.5 & 20.4 & 26.4 & 35.7 & 17.5 \\
\hline Colorado & 26 & 44 & 50 & 63 & 45.8 & 47.4 & 22.7 & 27.6 & 35.3 & 14.4 \\
\hline Oregon & 26 & 44 & 50 & 64 & 46.0 & 46.5 & 20.9 & 25.7 & 35.4 & 18.0 \\
\hline Nevada & 26 & 43 & 49 & 64 & 45.5 & 46.6 & 21.8 & 28.3 & 34.0 & 15.9 \\
\hline New Mexico & 25 & 43 & 49 & 63 & 45.0 & 45.7 & 22.2 & 24.5 & 35.7 & 17.6 \\
\hline Arizona & 25 & 41 & 48 & 62 & 44.0 & 44.6 & 22.6 & 26.0 & 32.9 & 18.5 \\
\hline Minnesota & 23 & 38 & 47 & 61 & 42.3 & 42.7 & 21.6 & 25.6 & 35.8 & 17.0 \\
\hline Pennsylvania & 24 & 40 & 48 & 63 & 43.8 & 43.5 & 20.7 & 23.6 & 35.9 & 19.8 \\
\hline Alaska & 22 & 36 & 44 & 57 & 39.8 & 41.9 & 25.0 & 26.9 & 37.6 & 10.5 \\
\hline Wisconsin & 23 & 38 & 46 & 61 & 42.0 & 42.2 & 21.2 & 24.7 & 36.2 & 17.9 \\
\hline Illinois & 23 & 38 & 46 & 60 & 41.8 & 42.5 & 22.2 & 26.7 & 34.5 & 16.5 \\
\hline Montana & 23 & 38 & 46 & 60 & 41.8 & 41.5 & 20.8 & 22.4 & 37.7 & 19.1 \\
\hline Maryland & 23 & 37 & 45 & 58 & 40.8 & 41.4 & 21.5 & 26.2 & 36.2 & 16.1 \\
\hline Delaware & 23 & 36 & 45 & 59 & 40.8 & 40.7 & 21.4 & 24.6 & 35.3 & 18.7 \\
\hline Michigan & 21 & 35 & 43 & 57 & 39.0 & 39.0 & 20.8 & 24.5 & 36.6 & 18.1 \\
\hline Florida & 23 & 36 & 44 & 57 & 40.0 & 39.2 & 19.7 & 24.0 & 34.3 & 22.0 \\
\hline Ohio & 20 & 34 & 43 & 56 & 38.3 & 38.2 & 20.7 & 24.6 & 36.3 & 18.5 \\
\hline Iowa & 20 & 34 & 43 & 56 & 38.3 & 38.2 & 21.7 & 23.8 & 35.0 & 19.6 \\
\hline Virginia & 19 & 33 & 40 & 54 & 36.5 & 37.3 & 22.3 & 26.6 & 35.3 & 15.9 \\
\hline Wyoming & 19 & 32 & 39 & 54 & 36.0 & 36.6 & 22.8 & 24.2 & 36.7 & 16.3 \\
\hline Kansas & 19 & 32 & 40 & 54 & 36.3 & 36.7 & 23.0 & 24.7 & 34.6 & 17.7 \\
\hline South Dakota & 18 & 31 & 40 & 54 & 35.8 & 35.8 & 22.5 & 23.3 & 35.2 & 19.0 \\
\hline Indiana & 17 & 30 & 38 & 53 & 34.5 & 34.9 & 22.0 & 25.5 & 35.2 & 17.3 \\
\hline North Dakota & 16 & 30 & 39 & 53 & 34.5 & 35.1 & 25.0 & 22.3 & 34.1 & 18.7 \\
\hline Missouri & 17 & 30 & 38 & 52 & 34.3 & 34.4 & 22.0 & 24.5 & 35.2 & 18.3 \\
\hline Idaho & 16 & 30 & 37 & 51 & 33.5 & 34.3 & 23.1 & 25.7 & 34.1 & 17.1 \\
\hline Nebraska & 16 & 29 & 36 & 51 & 33.0 & 33.4 & 22.9 & 24.6 & 34.5 & 18.0 \\
\hline West Virginia & 16 & 29 & 37 & 52 & 33.5 & 32.6 & 18.9 & 23.9 & 37.0 & 20.3 \\
\hline Texas & 16 & 28 & 35 & 48 & 31.8 & 33.2 & 24.3 & 28.5 & 33.0 & 14.2 \\
\hline $\begin{array}{c}\text { North } \\
\text { Carolina }\end{array}$ & 15 & 27 & 34 & 47 & 30.8 & 31.2 & 21.6 & 26.8 & 34.6 & 17.0 \\
\hline Georgia & 14 & 26 & 33 & 45 & 29.5 & 30.6 & 22.9 & 28.5 & 34.2 & 14.4 \\
\hline Louisiana & 15 & 26 & 33 & 46 & 30.0 & 30.7 & 23.6 & 25.2 & 34.8 & 16.3 \\
\hline $\begin{array}{c}\text { South } \\
\text { Carolina }\end{array}$ & 14 & 24 & 31 & 44 & 28.3 & 28.4 & 22.0 & 25.0 & 35.1 & 17.9 \\
\hline Kentucky & 13 & 23 & 30 & 44 & 27.5 & 27.5 & 21.2 & 25.9 & 35.6 & 17.4 \\
\hline Tennessee & 12 & 23 & 29 & 42 & 26.5 & 26.6 & 21.1 & 26.0 & 35.3 & 17.5 \\
\hline Utah & 11 & 20 & 26 & 37 & 23.5 & 25.5 & 28.9 & 29.1 & 28.9 & 13.1 \\
\hline Oklahoma & 12 & 21 & 27 & 40 & 25.0 & 25.2 & 23.0 & 24.8 & 34.3 & 17.9 \\
\hline Arkansas & 12 & 21 & 27 & 40 & 25.0 & 24.9 & 21.6 & 25.0 & 34.4 & 19.0 \\
\hline Mississippi & 10 & 19 & 25 & 36 & 22.5 & 22.9 & 22.9 & 25.3 & 34.6 & 17.2 \\
\hline Alabama & 10 & 19 & 25 & 36 & 22.5 & 22.9 & 23.6 & 24.5 & 34.2 & 17.6 \\
\hline
\end{tabular}


Case Western Reserve Law Review · Volume $64 \cdot$ Issue $3 \cdot 2014$

Marriage of Necessity

Table A7 (continued): Support for Same-Sex Marriage by Age, With and Without the Oldest Generation (65 and Older)

\begin{tabular}{|c|c|c|c|c|c|c|c|c|}
\hline $\begin{array}{c}\text { STATE/ } \\
\text { SUPPORT }\end{array}$ & $45-64$ & $30-44$ & $18-29$ & Average & $\begin{array}{c}\text { Weighted } \\
\text { Average }\end{array}$ & $18-29$ & $30-44$ & $45-64$ \\
\hline Massachusetts & 53 & 61 & 74 & 62.67 & 60.99 & 26.4 & 30.7 & 42.9 \\
\hline Vermont & 49 & 57 & 70 & 58.67 & 56.41 & 24.7 & 27.8 & 47.5 \\
\hline Rhode Island & 49 & 58 & 71 & 59.33 & 57.69 & 27.5 & 29.2 & 43.2 \\
\hline Connecticut & 49 & 57 & 69 & 58.33 & 56.28 & 24.1 & 30.6 & 45.2 \\
\hline New York & 47 & 56 & 70 & 57.67 & 56.03 & 27.0 & 31.4 & 41.7 \\
\hline New Hampshire & 47 & 56 & 69 & 57.33 & 54.72 & 23.1 & 29.4 & 47.5 \\
\hline Maine & 46 & 56 & 69 & 57.00 & 54.04 & 22.4 & 28.9 & 48.7 \\
\hline California & 46 & 53 & 67 & 55.33 & 54.20 & 28.1 & 32.7 & 39.2 \\
\hline Washington & 45 & 53 & 66 & 54.67 & 53.05 & 26.3 & 31.5 & 42.2 \\
\hline Hawaii & 46 & 53 & 66 & 55.00 & 53.42 & 26.3 & 30.8 & 42.9 \\
\hline New Jersey & 45 & 53 & 67 & 55.00 & 53.01 & 24.8 & 32.0 & 43.3 \\
\hline Colorado & 44 & 50 & 63 & 52.33 & 50.98 & 26.5 & 32.3 & 41.2 \\
\hline Oregon & 44 & 50 & 64 & 52.67 & 50.98 & 25.5 & 31.3 & 43.1 \\
\hline Nevada & 43 & 49 & 64 & 52.00 & 50.46 & 25.9 & 33.6 & 40.4 \\
\hline New Mexico & 43 & 49 & 63 & 51.67 & 50.17 & 26.9 & 29.7 & 43.3 \\
\hline Arizona & 41 & 48 & 62 & 50.33 & 49.05 & 27.7 & 32.0 & 40.4 \\
\hline Minnesota & 38 & 47 & 61 & 48.67 & 46.77 & 26.1 & 30.8 & 43.1 \\
\hline Pennsylvania & 40 & 48 & 63 & 50.33 & 48.28 & 25.8 & 29.4 & 44.8 \\
\hline Alaska & 36 & 44 & 57 & 45.67 & 44.27 & 27.9 & 30.0 & 42.0 \\
\hline Wisconsin & 38 & 46 & 61 & 48.33 & 46.34 & 25.8 & 30.1 & 44.1 \\
\hline Illinois & 38 & 46 & 60 & 48.00 & 46.42 & 26.6 & 32.0 & 41.4 \\
\hline Montana & 38 & 46 & 60 & 48.00 & 45.87 & 25.7 & 27.6 & 46.6 \\
\hline Maryland & 37 & 45 & 58 & 46.67 & 44.89 & 25.7 & 31.3 & 43.1 \\
\hline Delaware & 36 & 45 & 59 & 46.67 & 44.78 & 26.3 & 30.3 & 43.4 \\
\hline Michigan & 35 & 43 & 57 & 45.00 & 42.99 & 25.4 & 29.9 & 44.6 \\
\hline Florida & 36 & 44 & 57 & 45.67 & 43.76 & 25.2 & 30.8 & 44.0 \\
\hline Ohio & 34 & 43 & 56 & 44.33 & 42.30 & 25.4 & 30.2 & 44.5 \\
\hline Iowa & 34 & 43 & 56 & 44.33 & 42.58 & 26.9 & 29.5 & 43.6 \\
\hline Virginia & 33 & 40 & 54 & 42.33 & 40.77 & 26.5 & 31.6 & 42.0 \\
\hline Wyoming & 32 & 39 & 54 & 41.67 & 40.01 & 27.2 & 28.9 & 43.9 \\
\hline Kansas & 32 & 40 & 54 & 42.00 & 40.54 & 27.9 & 30.0 & 42.1 \\
\hline South Dakota & 31 & 40 & 54 & 41.67 & 39.98 & 27.8 & 28.8 & 43.4 \\
\hline Indiana & 30 & 38 & 53 & 40.33 & 38.59 & 26.6 & 30.8 & 42.5 \\
\hline North Dakota & 30 & 39 & 53 & 40.67 & 39.52 & 30.7 & 27.4 & 41.9 \\
\hline Missouri & 30 & 38 & 52 & 40.00 & 38.32 & 26.9 & 30.0 & 43.1 \\
\hline Idaho & 30 & 37 & 51 & 39.33 & 38.02 & 27.9 & 31.0 & 41.1 \\
\hline Nebraska & 29 & 36 & 51 & 38.67 & 37.24 & 27.9 & 30.0 & 42.1 \\
\hline West Virginia & 29 & 37 & 52 & 39.33 & 36.84 & 23.7 & 30.0 & 46.3 \\
\hline Texas & 28 & 35 & 48 & 37.00 & 36.00 & 28.4 & 33.2 & 38.5 \\
\hline North Carolina & 27 & 34 & 47 & 36.00 & 34.46 & 26.0 & 32.3 & 41.7 \\
\hline Georgia & 26 & 33 & 45 & 34.67 & 33.41 & 26.7 & 33.3 & 39.9 \\
\hline Louisiana & 26 & 33 & 46 & 35.00 & 33.76 & 28.3 & 30.2 & 41.6 \\
\hline South Carolina & 24 & 31 & 44 & 33.00 & 31.50 & 26.8 & 30.5 & 42.7 \\
\hline Kentucky & 23 & 30 & 44 & 32.33 & 30.58 & 25.6 & 31.3 & 43.0 \\
\hline Tennessee & 23 & 29 & 42 & 31.33 & 29.75 & 25.6 & 31.6 & 42.9 \\
\hline Utah & 20 & 26 & 37 & 27.67 & 27.66 & 33.3 & 33.4 & 33.3 \\
\hline Oklahoma & 21 & 27 & 40 & 29.33 & 28.13 & 28.0 & 30.3 & 41.7 \\
\hline Arkansas & 21 & 27 & 40 & 29.33 & 27.91 & 26.6 & 30.9 & 42.5 \\
\hline Mississippi & 19 & 25 & 36 & 26.67 & 25.54 & 27.7 & 30.6 & 41.7 \\
\hline Alabama & 19 & 25 & 36 & 26.67 & 25.66 & 28.7 & 29.8 & 41.6 \\
\hline
\end{tabular}


Case Western Reserve Law Review · Volume 64 · Issue $3 \cdot 2014$ Marriage of Necessity

Table A7 (continued): Support for Same-Sex Marriage by Age, With and Without the Oldest Generation (65 and Older)

\begin{tabular}{|c|c|c|c|c|c|c|c|c|c|c|c|c|c|c|c|c|}
\hline \multirow{2}{*}{$\begin{array}{l}\frac{\pi}{\pi} \\
\frac{\pi}{20}\end{array}$} & \multicolumn{5}{|c|}{ With Silent Generation } & \multicolumn{4}{|c|}{ Weighted Avg. } & \multicolumn{4}{|c|}{$\begin{array}{c}\text { Without Silent } \\
\text { Generation }\end{array}$} & \multicolumn{3}{|c|}{ Weighted Avg. } \\
\hline & $\begin{array}{l}\stackrel{N}{\sim} \\
\stackrel{\infty}{\sim}\end{array}$ & $\begin{array}{l}\text { H } \\
\text { 官 }\end{array}$ & $\begin{array}{l}\text { 落 } \\
\text { 字 }\end{array}$ & 㕝 & $\sum_{S}$ & $\begin{array}{l}\stackrel{N}{N} \\
\stackrel{\infty}{-1}\end{array}$ & 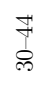 & $\begin{array}{l}\text { 落 } \\
\text { 采 }\end{array}$ & 㕝 & 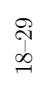 & $\begin{array}{l}\text { J } \\
\text { 品 }\end{array}$ & $\begin{array}{l}\text { त् } \\
\text { 字 }\end{array}$ & 点 & $\begin{array}{l}\stackrel{\infty}{N} \\
\infty \\
\sim\end{array}$ & $\begin{array}{l}\text { \# } \\
\text { 帛 }\end{array}$ & 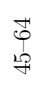 \\
\hline MA & 17.0 & 19.8 & 27.7 & 13.8 & 78.3 & 21.7 & 25.3 & 35.4 & 17.6 & 17.0 & 19.8 & 27.7 & 645 & 26.4 & 30.7 & 42.9 \\
\hline VT & 16.0 & 18.0 & 30.8 & 146 & 794 & 20.2 & 22.7 & 38.8 & 18.4 & 16.0 & 18.0 & 30.8 & 648 & 24.7 & 27.8 & 47.5 \\
\hline RI & 177.7 & 18.8 & 27.8 & 144 & 78.7 & 22.5 & 23.9 & 35.3 & 18.3 & 177.7 & 18.8 & 27.8 & 643 & 27.5 & 29.2 & 43.2 \\
\hline $\mathrm{CT}$ & 15.2 & $\begin{array}{l}19.3 \\
\end{array}$ & 28.5 & 142 & 77.2 & 19.7 & 25.0 & 36.9 & 18.4 & 15.2 & 19.3 & 28.5 & 63.0 & 24.1 & 30.6 & 45.2 \\
\hline NY & 173 & 20.1 & 26.7 & 135 & 77.6 & 22.3 & & 34.4 & 17.4 & 173 & 20.1 & 26.7 & 641 & 27.0 & 31.4 & 41.7 \\
\hline $\mathrm{NH}$ & 149 & 19.0 & 30.7 & 135 & 78.1 & 19.1 & 24.3 & 39.3 & 17.3 & 149 & 190 & 30.7 & 646 & 23.1 & 29.4 & 47.5 \\
\hline ME & 142. & 18.3 & 30.9 & 15.9 & 79.3 & 17.9 & 23.1 & 39.0 & 20.1 & 142 & 18.3 & 30.9 & 63.4 & 22.4 & 28.9 & 48.7 \\
\hline $\mathrm{CA}$ & 17.9 & 20.8 & 249 & 11.4 & 75.0 & 23.9 & 27.7 & 33.2 & 15.2 & 17.9 & 20.8 & 249 & 63.6 & 28.1 & 32.7 & 39.2 \\
\hline WA & $\begin{array}{l}16.9 \\
\end{array}$ & 20.2 & 27.1 & 123 & 76.5 & 22.1 & 26.4 & 35.4 & 16.1 & 16.9 & 20.2 & 27.1 & 642 & 26.3 & 31.5 & 42.2 \\
\hline $\mathrm{HI}$ & 16.7 & 19.5 & 27.2 & 143 & 77.7 & 21.5 & 25.1 & 35.0 & 18.4 & 16.7 & 19.5 & 27.2 & 63.4 & 26.3 & 30.8 & 42.9 \\
\hline NJ & $\begin{array}{ll}15.8 \\
\end{array}$ & 20.4 & 27.6 & 135 & 773 & 20.4 & 26.4 & 35.7 & 17.5 & 15.8 & 204 & 27.6 & 63.8 & 24.8 & 32.0 & 43.3 \\
\hline $\mathrm{CO}$ & 17.2 & 20.9 & 26.7 & 10.9 & 75.7 & 22.7 & 27. & 35.3 & 14.4 & 17.2 & 20.9 & 267 & 648 & 26.5 & 32.3 & 41.2 \\
\hline OR & 16.2 & 19.9 & 27.4 & 13.9 & 77.4 & 20.9 & 25.7 & 35.4 & 18.0 & 16.2 & 19.9 & 27.4 & 63.5 & 25.5 & 31.3 & 43.1 \\
\hline NV & 16.4 & 21.3 & 25.6 & 12.0 & 75.3 & 21.8 & 28.3 & 34.0 & 15.9 & 16.4 & 21.3 & 25.6 & 63.3 & 25.9 & 33.6 & 40.4 \\
\hline NM & 16.6 & 18.3 & 26.7 & 132 & 748 & 22.2 & 24.5 & 35.7 & 17.6 & 16.6 & 18.3 & 26.7 & 61.6 & 26.9 & 29.7 & 43.3 \\
\hline $\mathrm{AZ}$ & 16.8 & 19.4 & 245 & 138 & 745 & 22.6 & 26.0 & 32.9 & 18.5 & 16.8 & 194 & 245 & 60.7 & 27.7 & 32.0 & 40.4 \\
\hline MN & 16.4 & 19.4 & 27.1 & 129 & 75.8 & 21.6 & 25.6 & 35.8 & 17.0 & 16.4 & 194 & 27.1 & 62.9 & 26.1 & 30.8 & 43.1 \\
\hline $\mathrm{PA}$ & 16.1 & 18.4 & 28.0 & 15.4 & 77.9 & 20.7 & 23.6 & 35.9 & 19.8 & 16.1 & 18.4 & 28.0 & 62.5 & 25.8 & 29.4 & 44.8 \\
\hline AK & 18.4 & 19.8 & 27.7 & 7.7 & 73.6 & 25.0 & 26 & 37.6 & 10.5 & 184 & 19.8 & 27.7 & 65.9 & 27.9 & 30.0 & 42.0 \\
\hline WI & 162 & 18.9 & 27.7 & 13.7 & 76.5 & 21. & 24. & 36. & 17.9 & 16. & 18.9 & 27.7 & 628 & 25.8 & 30.1 & 44.1 \\
\hline $\mathrm{IL}$ & 16.8 & 20.2 & 26.1 & 125 & 75.6 & 22.2 & 26.7 & 34.5 & 16.5 & 16.8 & 20.2 & 26.1 & 63.1 & 26.6 & 32.0 & 41.4 \\
\hline MT & 16.1 & 1773 & 29.2 & 148 & 77.4 & 20.8 & 22.4 & $\begin{array}{l}37.7 \\
\end{array}$ & $\begin{array}{l}19.1 \\
\end{array}$ & 16.1 & 173 & 29.2 & 626 & 25.7 & 27.6 & 46.6 \\
\hline MD & 16.5 & 20.1 & 27.7 & 123 & 76.6 & 21.5 & 26 . & 36.2 & 16.1 & 16.5 & 20.1 & 27.7 & 643 & 25.7 & 31.3 & 43.1 \\
\hline $\mathrm{DE}$ & 16.5 & 19.0 & 27.2 & 144 & 77.1 & 21 & 24 & 35 & 18.7 & 16.5 & 190 & 27.2 & 627 & 26 . & 30.3 & 43.4 \\
\hline MI & 15.9 & 18.7 & 27.9 & 13.8 & 76.3 & 20.8 & 24.5 & 36.6 & 18.1 & 15.9 & 18.7 & 27.9 & 625 & 25.4 & 29.9 & 44.6 \\
\hline FL & 15.5 & 18.9 & 27.0 & 173 & 78.7 & $\begin{array}{l}19.7 \\
\end{array}$ & 24.0 & 34.3 & 22.0 & 15.5 & 18.9 & 27.0 & 61.4 & 25.2 & 30.8 & 44.0 \\
\hline $\mathrm{OH}$ & 15.8 & 18.8 & 27.7 & 141 & 764 & 20 & & 36 & 18.5 & 15.8 & 18.8 & 27.7 & 623 & 25 & 30.2 & 44.5 \\
\hline IA & 16.5 & 18.1 & 26.7 & 14. & 762 & 21. & 20 & 35. & 19.6 & 16.5 & 18.1 & 26.7 & 61.3 & 26.9 & 29.5 & 43.6 \\
\hline VA & $\begin{array}{ll}17.1 \\
\end{array}$ & 20.4 & 27.1 & 122 & 76.8 & 22.3 & 26.6 & 35.3 & 15.9 & 17.1 & 20.4 & 27.1 & 646 & 26.5 & 31.6 & 42.0 \\
\hline WY & $\begin{array}{ll}173 \\
\end{array}$ & 184 & 27.9 & 124 & 76.0 & 22.8 & 24.2 & 36.7 & 16.3 & 173 & 184 & 27.9 & 63.6 & 27.2 & 28.9 & 43.9 \\
\hline KS & $\begin{array}{ll}17.1 \\
\end{array}$ & 184 & 25 & 132 & 745 & 23. & & 34.6 & 17.7 & 17.1 & 184 & 25.8 & 61.3 & 27.9 & 30.0 & 42.1 \\
\hline SD & 16.9 & 17.5 & 26.4 & 143 & 75.1 & 22 & 23. & 35.2 & 19.0 & 16.9 & 17.5 & 26.4 & 60.8 & 27.8 & 28.8 & 43.4 \\
\hline IN & 16.6 & 19.2 & 26.5 & 130 & 753 & 22.0 & 25.5 & 35.2 & 17.3 & 16.6 & 192 & 26.5 & 623 & 26.6 & 30.8 & 42.5 \\
\hline ND & $\begin{array}{l}19.4 \\
\end{array}$ & 173 & $\gamma$ & $4=$ & 77.7 & 25.0 & 22 & 34.1 & 18.7 & 19.4 & 17.3 & 26.5 & 63 & 30.7 & 27.4 & 41.9 \\
\hline MO & 16.8 & 18.7 & 2 & 14 & 76.4 & 22. & 24 & 35. & 18.3 & 16.8 & 18.7 & 26.9 & 62 & 26.9 & 30.0 & 43.1 \\
\hline ID & 16.8 & 18.7 & 248 & 124 & 72.7 & 23.1 & 25.7 & 34.1 & 17.1 & 16.8 & 18.7 & 248 & 60.3 & 27.9 & 31.0 & 41.1 \\
\hline $\mathrm{NE}$ & 17.1 & 184 & 25.8 & 135 & 748 & 22.9 & 24.6 & 34.5 & 18.0 & 17.1 & 184 & 25.8 & 613 & 27.9 & 30.0 & 42.1 \\
\hline WV & 14.9 & 18.9 & 29.2 & 16 & 79.0 & 18.9 & 23 & 37.0 & 20.3 & 149 & 18.9 & 29.2 & 63.0 & 23.7 & 30.0 & 46.3 \\
\hline TX & 17.7 & 20.7 & 24 & & 72.7 & 24. & 20 & 33. & 14.2 & 177.7 & 20.7 & 240 & 62 & 28.4 & 33.2 & 38.5 \\
\hline $\mathrm{NC}$ & 16.4 & 20.4 & 26.3 & 129 & 76.0 & 21.6 & 26.8 & 34.6 & 17.0 & 16.4 & 20.4 & 263 & 63.1 & 26.0 & 32.3 & 41.7 \\
\hline GA & 17.0 & 21.2 & 25.4 & 10.7 & 743 & 22.9 & 28.5 & 34.2 & 14.4 & 17.0 & 21.2 & 25.4 & 63.6 & 26.7 & 33.3 & 39.9 \\
\hline LA & 17.8 & 19.0 & 26.2 & 123 & 75.3 & 23.6 & 25 & 34.8 & 16.3 & 17.8 & 190 & 26.2 & 63.0 & 28.3 & 30.2 & 41.6 \\
\hline $\mathrm{SC}$ & 16.9 & 19.2 & 20.9 & 15 & 76.7 & 22. & & 35.1 & 17.9 & 16.9 & 19.2 & 26.9 & 63.0 & 26.8 & 30.5 & 42.7 \\
\hline $\mathrm{KY}$ & 162 & 19.8 & 27.2 & 133 & 76.5 & 21.2 & 25. & 35.6 & 17.4 & 16.2 & 198 & 27.2 & 63.2 & 25.6 & 31.3 & 43.0 \\
\hline TN & 16.1 & 19.9 & 27.0 & 13.4 & 76.4 & 21.1 & 26.0 & 35.3 & 17.5 & 16.1 & 19.9 & 27.0 & 63.0 & 25.6 & 31.6 & 42.9 \\
\hline UT & 19.8 & 19.9 & 19.8 & 9.0 & 68.5 & 28.9 & 29.1 & 28.9 & 13.1 & 19.8 & 19.9 & 19.8 & 59.5 & 33.3 & 33.4 & 33.3 \\
\hline OK & 173 & 18.7 & 20.8 & 13 & 75.3 & 23. & 24 & 34.3 & 17.9 & 173 & 18.7 & 25.8 & 61.8 & 28.0 & 0.3 & 41.7 \\
\hline $\mathrm{AR}$ & 16.3 & 18.9 & 26.0 & 144 & 75.6 & 21.6 & 25. & 34.4 & 19.0 & 16.3 & 18.9 & 26.0 & 61.2 & 26.6 & 30.9 & 42.5 \\
\hline MS & 17.1 & 18.9 & 25.8 & 128 & 746 & 22.9 & 25.3 & 34.6 & 17.2 & 17.1 & 18.9 & 25.8 & 61.8 & 27.7 & 30.6 & 41.7 \\
\hline $\mathrm{AL}$ & 18.5 & 192 & 26.8 & 138 & 78.3 & 23.6 & 24.5 & 34.2 & 17.6 & 18.5 & 19.2 & 26.8 & 645 & 28.7 & 29.8 & 41.6 \\
\hline
\end{tabular}

335. For an explanation of where the data in this Table are taken from, and how the weighted averages were generated, see supra note 166. 